\title{
Electrospinning: designed architectures for energy conversion and storage devices
}

\author{
Sara Cavaliere ${ }^{*,}$, , Surya Subianto ${ }^{a}$, Iuliia Savych ${ }^{\mathrm{a}}$, Deborah J. Jones ${ }^{\mathrm{a}}$ and Jacques Rozière ${ }^{\mathrm{a}}$ \\ Received (in $X X X, X X X)$ Xth $X X X X X X X X X 20 X X$, Accepted Xth $X X X X X X X X X 20 X X$ \\ DOI: 10.1039/b000000x
}

\begin{abstract}
Electrospinning is attracting close interest as a versatile fabrication method for one dimensional mesostructured organic, inorganic and hybrid nanomaterials of controlled dimensions prepared as randomly oriented or oriented continuous nanofibres that can present internal compositional organisation such as core-sheath, hollow or porous fibre, or even multichannel microtube arrangements. The dimensionality, directionality and compositional flexibility of electrospun nanofibres and mats are increasing being investigated for the targeted development of electrode and electrolyte materials. Specific properties associated with the nano-scale features such high surface to volume and aspect ratios, low density and high pore volume allow performance improvements in energy conversion and storage devices. We review here the application of electrospinning for designing architectured nanofibre materials for dye sensitised solar cells, fuel cells, lithium ion batteries and supercapacitors, with particular emphasis on improved energy and power density imparted by performance improvement to, inter alia, ionic conductivity, cyclability, reversibility, interfacial resistance and electrochemical stability, as well as mechanical strength, of electrospun electrode and electrolyte components.
\end{abstract}

\section{Table of contents}

1. Introduction

2. Principle and applications of electrospinning $\quad 2$

3. Electrospun materials in energy conversion and storage

3.a. Electrospun nanofibres for fuel cells

3.a.1. Electrospun catalysts for fuel cells

3.a.2. Electrocatalysts on electrospun support materials

3.a.3. Electrolyte membrane

3.b. Electrospun materials for dye-sensitised solar cells

3.b.1. Photoanodes

3.b.2 Counter electrodes

3.b.3. DSC electrolytes

3.c. Electrospun nanofibres in lithium-ion batteries

3.c.1 Electrode materials

3.c. $2 \mathrm{Li}$-ion battery separators

3.d. Electrospun fibres for supercapacitors

4. Conclusions and future perspectives

\section{Introduction}

Energy conversion and energy storage are ever more important in the context of escalating energy requirements and increasing world population. Future generations of efficient energy conversion and storage devices are required to meet this challenge, whereby the conversion and storage of energy from renewable sources is bound to play an increasingly relevant role. Rechargeable, reversible and highly durable conversion and storage systems are required, consistent with a responsible utilisation of global reserves of strategic elements, and avoiding their rarefaction. The current challenges associated with the development of energy conversion and storage devices are well-documented in review articles dedicated to electrode and electrolyte developments for lithium ion batteries $^{1,2,3}$ supercapacitors $4,5,6,7,8$, proton exchange membrane fuel cells $9,10,11,12,13$ and dye sensitised solar cells 14, 15, 16, 17. To achieve high energy and power density and system efficiency, designed functional materials are needed that associate the required electrochemical properties for improved performance, with chemical and electrochemical stability, while leaving a minimally low environmental footprint. Clearly the selection of appropriate electrolyte and electrode structure and architecture is fundamental in determining device performance.

Materials with nanometer-scale dimensions have attracted a great deal of attention over the last 20 years or so. Nanomaterials and nanostructured materials, including nano-coatings and films and nanocomposites, are at the epicentre of energy materials since this corresponds to the length scale over which many of the elementary steps such as 


\section{Cite this: DOI: $10.1039 / \mathrm{c0xx00000x}$}

charge transfer or molecular rearrangement occur, and because their reduced dimensions and the effect of surface properties on their behaviour provide a high volume fraction of interfaces and favour increased reaction rates. Exploring materials chemistry down to the nanoscale to develop novel solutions for energy applications is possible by a systematic approach involving new methods for manipulation, assembly and characterisation.

Targeted development of new one-dimensional (1D) nanostructures, such as continuous nanofibres (NFs), large aspect ratio nanowires (NWs), and nanorods $(\mathrm{NRs})^{18,19,20,21}$, is attracting much interest because of the dependence of their physical properties on directionality. Conventionally these materials are produced by the bottom-up approach, i.e. by selfassembly of the target material from vapour, liquid or solid phases through nucleation and growth under optimised conditions (hydrothermal synthesis,... $)^{22}$. Most 1D nanomaterial synthetic methods involve multiple steps: for instance, the fabrication/removal of templates and the catalyst elaboration. The different process conditions in each step often limit the practical device quality. Among the methods for generating fibrous nanostructure, electrospinning is a top-down simple, versatile and cost-effective approach allowing the fabrication of nanofibres in a continuous process and at long-length scales.

\section{Principle and applications of electrospinning}

Electrospinning is a process leading to the formation of ultra-fine fibres with diameters in the micrometre to nanometre range, starting from molten polymers or polymers in solution. Some excellent reviews describing the technique are available 2324,25 , $26,27,28,29,30,31,32,33$. Electrospinning is based on the application of an electric field to a drop of fluid polymer on the tip of a spinneret. As the intensity of the electric field increases, the hemispherical surface of the solution at the tip of the capillary tube elongates to form a conical shape known as the Taylor cone (see Fig. 1). When the applied electric field reaches a critical value, the repulsive electrical forces overcome the surface tension of the drop. A charged jet of the solution is then ejected from the tip of the Taylor cone and an unstable and rapid whipping of the jet occurs between the tip and the collector leading to the evaporation of the solvent and the formation of solidified continuous, ultra-thin fibres on the collector $^{34}$.
The conventional electrospinning set-up consists of three major components: a high voltage $(\mathrm{kV})$ power supply, a spinneret (a syringe or pipette tip) and a grounded collector (typically a metal plate or a rotating mandrel) (see Fig. 1).

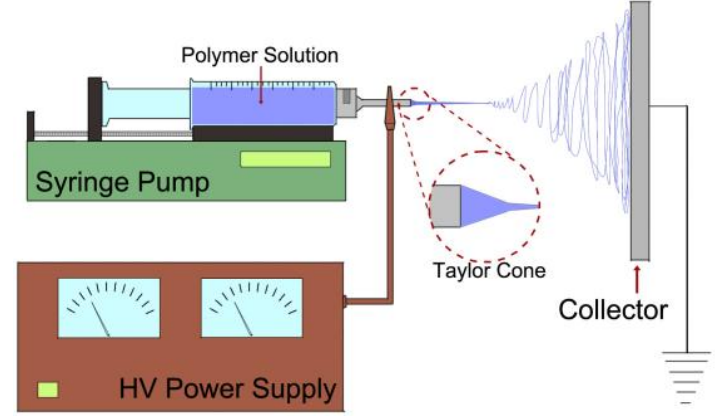

Fig. 1 : Scheme of a conventional electrospinning set-up.

Electrospun nanofibres present specific properties, such as high surface/volume and aspect ratios, leading to low density and high pore volume, and exceptional mechanical strength ${ }^{23}$. Electrospinning, first studied by Zeleny ${ }^{35}$ in 1914 and patented by Formhals ${ }^{36}$ in 1934 , was initially exclusively applied to polymers ${ }^{30}$. During the last two decades, electrospinning has attracted renewed attention due to the huge potential that the technique presents for nanomaterials and nanotechnologies ${ }^{37}$. Indeed, the new properties appearing at the nanoscale (quantum effect, superparamagnetism, electronic effects) $)^{38,39}$ have led to intense research on nanomaterials ${ }^{40}$. The applicability of electrospinning has been then extended to the production of hybrids (e.g. polymers loaded with chromophores, magnetic nanoparticles, biomolecules) $)^{41,} 42,43,44$ and inorganic ${ }^{31} 32$ onedimensional nanomaterials, using a range of precursor types. Electrospinning has the advantages of simplicity, efficiency, low cost, high yield and high degree of reproducibility of the obtained materials. The versatility of electrospinning is not only related to the nature of the precursors and electrospun materials, but also extends to the fibre assemblies and architectures. Modifying solution and processing parameters $^{45}, 46$ and/or set-up geometries ${ }^{33}$ allows the preparation of complex nanostructures with controllable hierarchical features such as nonwoven, aligned or patterned fibres, nanoribbons, nanorods, random three dimensional structures, sub-micron spring and convoluted fibres with controlled diameters $^{47,48}$. The elaboration of such designed assemblies in situ (and not by a subsequent physical manipulation) allows their customisation to adapt them to specific applications. Furthermore, the possibility of co-electrospinning different solutions 


\section{Cite this: DOI: $10.1039 / \mathrm{c0xx00000x}$}

using specially designed spinnerets leads to the elaboration of core-sheath ${ }^{49}$, hollow fibres ${ }^{50,51,52}$, porous fibres $^{53}$, and multichannel microtubes ${ }^{54,55}$. The properties of the obtained designed fibres can also be tuned by the addition in situ, or by further functionalisation, of molecular species or nanoparticles. ${ }^{56}$. It is important to note that although electrospun nanofibres are almost one-dimensional, their mats are generally disordered, unless special measures are taken, and effective techniques for producing aligned nanofibres of sufficient fibre length and at large scale are required. Bridging and alignment of electrospun fibres across slotted electrodes has been described $^{33,57}$ although the process is complex and the distance between the electrodes is limited. A needleimprinting method, using a movable needle system in combination with a thin conveyor belt comprised of an insulation material that slides on top of the grounded collector plate, also allows fibre alignment, and here the continuous process allows larger scale production of electrospun mats ${ }^{58}$. Continuous aligned polymer fibres have also been produced by simultaneous ejection from two needles with opposite voltages, and collecting the neutral yarn on a rotating shaft ${ }^{59}$ while continuous aligned ceramic fibres have been produced from a multi-jet/multi-collector system whereby the the spatial orientation of the nanofibres is controlled by the inducing effect of the converging electric field generated by thin metal wire collectors ${ }^{60}$.

This tremendous variety of electrospun nanofibres in term of materials, structures, architectures and functionalities explains the increased use of the electrospinning technique for the production of nanofibres and fabrics ${ }^{61}$ and membranes ${ }^{62,} 63,64$ elaborated from them. The extensive applications ${ }^{65}$ range from catalysis, structural applications requiring high mechanical strength, biology for tissue engineering, biomolecular machines, biosensors, nanoelectronics, optical, resonator, and opto- and magnetoelectronic devices, sensors, photocatalysis, biomedical fuel cells, solar cells, membranes (see Fig. 2) $66,67,68,69,70$.

Due to its inherent adaptability and applicability, and as indicated recently ${ }^{71,72}$, the electrospinning technique can be applied to the preparation of different components of energy materials, from polymer electrolytes to ceramic and metallic electrodes: The aim of this review is then to give a detailed overview of recent advances in the application of materials issued from electrospinning in energy devices including fuel cells (FCs), dyesensitised solar cells (DSCs), supercapacitors and Liion batteries (LIBs). The number of published research articles on this topic has significantly increased especially in recent years (see Fig. 3), showing the need for monitoring the present results and identifying the future challenges.

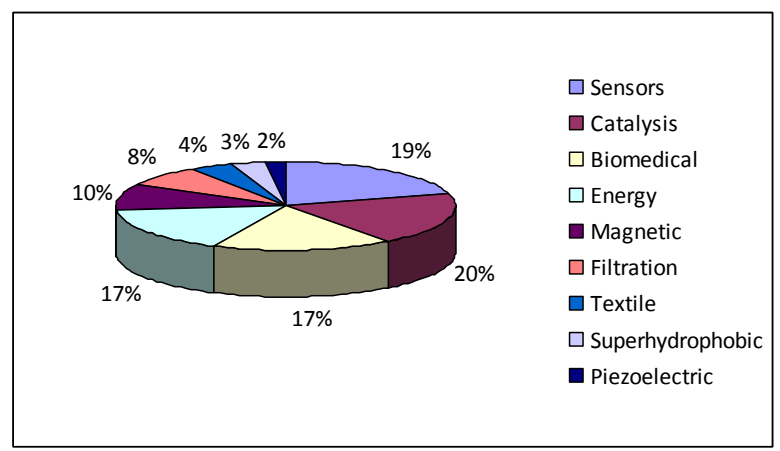

Fig. 2. Relative proportion of publications in main areas of applications of electrospinning in the period of 2000-2010 (Scifinder data: Keywords: electrospinning + type of application in the legend).

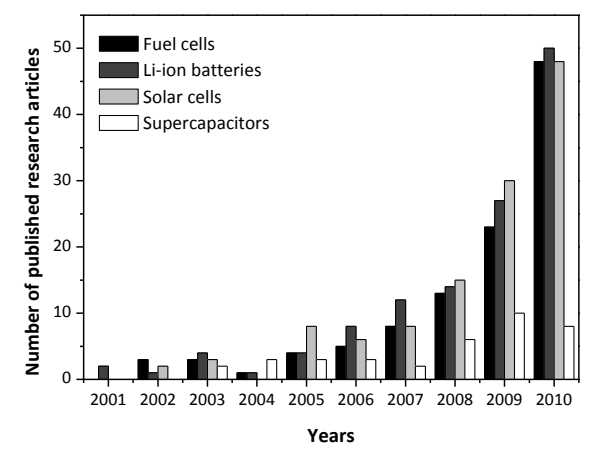

Fig. 3. Number of research articles concerning electrospun nanofibre applications in energy devices published in the period of 2001-2010 (Scifinder data: keywords electrospinning + fuel cells, electrospinning $+\mathrm{Li}$-ion batteries, electrospinning + solar cells, electrospinning + supercapacitors).

\section{Electrospun materials in energy conversion and storage}

\section{3.a. Electrospun nanofibres for fuel cells}

Fuel cells convert the chemical energy of a fuel into electricity for power generation with high efficiency. Using pure hydrogen and air, fuel cells produce only water, thus eliminating any pollution or emission at the point of use. Hydrocarbon fuels can also be used and, although their use is associated with local carbon dioxide emissions, there is great interest in direct methanol fuel cells for portable electronics applications, and in (bio)ethanol as a renewable fuel source for fuel cells. While portable applications represent early fuel cell markets, the main drivers for development of fuel cells are stationary and transportation usage. Renewed interest over the past 


\title{
Cite this: DOI: $10.1039 / \mathrm{c0xx00000x}$
}

\author{
www.rsc.org/xxxxxx
}

ARTICLE TYPE

two decades triggered by the need to integrate alternative energy carriers and thus energy conversion systems to improve energy sustainability, intense research and development endeavours have been pursued to advance materials performance and robustness, to increase lifetime and reduce costs. These efforts are currently dedicated to all components of the membrane electrode assembly: electrolyte membrane $\mathrm{e}^{73,74,75,76}$ (increase conductivity and high temperature and low relative humidity, improve mechanical strength), electrocatalyst (reduce platinum loading, increase mass and specific activity), ${ }^{77,78}$ and catalyst support material ${ }^{79,80}$ (stabilisation of carbon support to oxidation, alternative support materials). Elaboration of fuel cell nanomaterials of targeted architecture is increasingly considered as a powerful tool in reaching these goals, through the spatial organisation of catalytic metals to achieve efficient presentation of platinum to the reaction medium, ${ }^{81,} \quad 82, \quad 83, \quad 84$ optimised microstructural arrangements of polymer membranes, ${ }^{85},{ }^{86}$ and designed nanoporosity within carbon ${ }^{87,88}$, oxide ${ }^{89,90}$, or carbide $^{91}$ supports. The potential of electrospinning for fuel cell materials has been quickly recognised, and over a short period of time the literature in the field has burgeoned. Recent advances and new directions are described below and summarised in Tables 1-4.

\section{3.a.1. Electrospun catalysts for fuel cells}

Thus far there have been comparatively few studies on the use of electrospinning to synthesise electrocatalyts ${ }^{92,93,94,95,96,97}$, in contrast with its use to fabricate catalyst supports. This may be due to the difficulties in achieving an extremely fine fibre diameter $(<10 \mathrm{~nm})$ by electrospinning compared to other methods such as chemical vapour deposition. Nevertheless, the earliest publication was by Kim et al. regarding the synthesis of catalytic electrospun nanowires (NWs) of $\mathrm{Pt} / \mathrm{Rh}$ and $\mathrm{Pt} / \mathrm{Ru} \mathrm{NW}$ with $50 \mathrm{~nm}$ diameter ${ }^{94}$ (Fig. 4). The mass activity of PtRu NWs was better than the conventional catalyst of highly dispersed PtRu NPs on carbon. A NP/NW combination system was also studied, where Pt NPs on carbon were blended with electrospun Pt NWs. The mass activity of this combined electrocatalyst was higher per unit mass of Pt than using solely the conventional cathode catalysts of $\mathrm{Pt}$ on carbon. Shui et al. ${ }^{97}$ described the fabrication of centimetre-long nanowires of $\mathrm{Pt}$ by electrospinning, with the ultimate goal of removing the need for a catalyst support in the fuel cell electrode. These Pt NWs show a diameter of 5-17 nm, with the fibre formation (rather than other morphologies such as beads) dependant more on the type of carrier polymer (PVP) than the nature of the platinum precursor. In other recent work, Pt-Fe alloy nanowires prepared by electrospinning and dealloying were shown to present high specific activity for oxygen reduction ${ }^{98}$. Another approach was demonstrated by Su et al. ${ }^{99}$ who fabricated polyamide6 (PA6) nanofibres coated with a Pd layer of $\sim 85 \mathrm{~nm}$ thickness for the electrooxidation of alcohol in aqueous medium. The MEA incorporating the Pd/PA6 nanofibres provided high current density and enhanced performance which was attributed to the large surface area, reduced diffusion resistance, and excellent tolerance to $\mathrm{CO}$ poisoning.

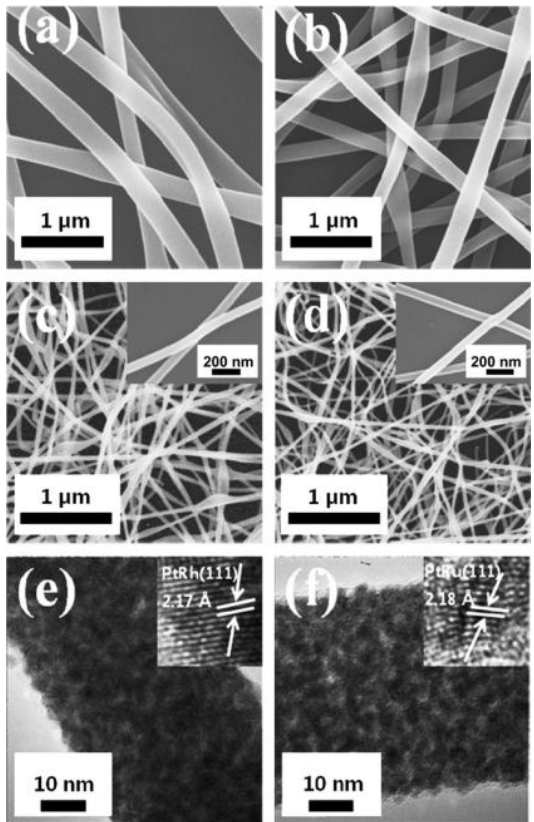

Fig. 4. FESEM images of as-spun (a) Pt-Rh precursor/PVP, (b) Pt-Ru precursor/PVP and bimetallic nanowires of (c) $\mathrm{PtRh}$ and (d) PtRu; insets of (c) and (d) show the diameter of bimetallic NWs. HRTEM images of (e) Pt1Rh1 NWs and (f) Pt1Ru1 NWs; insets of (e) and (f) are inverse fast fourier transform image of PtRh NWs and PtRu NWs. Reprinted from ref. 94 Copyright (2008), with permission from Elsevier.

\section{3.a.2. Electrocatalysts on electrospun support materials}

The support material for electrodes is a very crucial point in fuel cell development, impacting both performance and durability. The general requirements for electrocatalyst support materials are high electronic conductivity, high specific surface area and high electrochemical and chemical stability under fuel cell operating conditions. Interaction between catalytic metals and the support should also be considered in improving the performance. Such supports allow a high dispersion and a narrow size distribution of 


\section{Cite this: DOI: $10.1039 / \mathrm{c} 0 \mathrm{xx} 00000 \mathrm{x}$}

catalyst nanoparticles, favouring their maximum exploitation and rapid kinetics. They can also provide a way to decrease the metal loading, and then electrode costs that are one of the major bottlenecks of PEMFC (e.g. in the case of noble metals such Pt $)^{100}$. The durability of the catalyst is also greatly dependent on its support.

Carbon (e.g. commercial Vulcan XC-72) is the most common catalyst support for fuel cell applications due to its large surface area and high electronic conductivity. However, despite these advantages and relatively low cost, the use of carbon also presents one of the main challenges for long term fuel cell operation, namely carbon corrosion. Thus, significant research efforts have been directed to develop a carbon-based or alternative material which has improved corrosion resistance. Novel nanostructured carbon materials such as nanotubes ${ }^{101}$ and nanofibres ${ }^{80,} 102$ have received much attention as catalyst supports for PEM fuel cells. Indeed, the specific 1D morphology can improve the stability of the support materials with better utilisation of the electrocatalysts and the overall better performances and lifetime of the resulting electrodes. Recently, the electrospinning technique has been used as synthesis strategy for carbon materials with controlled diameters and structures.

Carbon nanofibres (CNFs) represents a promising support material for fuel cells as CNFs have increased conductivity over carbon particles. This is due to easier electron transfer along the aligned $\mathrm{CNF}$, in contrast to carbon particles where there are significant interfaces between the particles, which may add to the resistance of the system. Most studies have focused on carbon fibres derived from polyacrylonitrile (PAN) as they can be readily electrospun and their graphitisation method is well established. Phenolic resin-based carbon fibres with thin diameters and high conductivity have also been prepared ${ }^{103,}{ }^{104}$. Park et $a l .{ }^{105}$ developed electrospun PAN-based carbon nanofibres which have high surface area, shallow pores and rough surfaces leading to significantly higher Pt utilisation (69\%) in the Pt/CNF than with $\mathrm{Pt} /$ Vulcan XC-72R (35\%). The electrical conductivity of the electrospun CNFs carbonised at $1000{ }^{\circ} \mathrm{C}$ was also higher at $9.9 \mathrm{~S} \mathrm{~cm}^{-1}$, whereas the conductivity of Vulcan XC-72R was $4.5 \mathrm{~S} \mathrm{~cm}^{-1}$, which led to improved fuel cell performance of the electrospun electrode. Furthermore, it was found that the electrospun nanofibres have higher conductivity along the fibres than across them, indicating good electron transfer within the fibres.

Nataraj et al. ${ }^{106}$ aimed to fabricate CNFs with improved morphology and conductivity by incorporating various amounts of heteropolyacids (HPAs) into the PAN precursor. Increasing HPA content provided increasing electrical conductivity in HPA-containing fibres (however the overall conductivity of the HPA loaded CNFs was actually lower compared to pristine CNFs carbonised at 1000 ${ }^{\circ} \mathrm{C}$ ) and finer fibre diameters in the CNF mats, resulting in greater surface area. Another study by the same authors ${ }^{107}$ investigated the influence of nickel nitrate in the place of HPA, and a similar enhancement of surface area increasing nickel nitrate concentration were observed, as well as improved thermal stability. These effects were attributed to several factors, including the inorganic particles-polymer interaction and the increased conductivity of the electrospinning solution.

Electrospun fibres have also found application in alkaline fuel cells (AFCs). For instance, iron/cobalt/carbon electrospun nanofibre ( $\mathrm{FeCo} / \mathrm{CNF}$ ) composite electrocatalysts demonstrated comparable electrocatalytic activity and stability to commercial carbon-supported platinum (Pt/C) for ORR, a direct 4electron reduction pathway, and better ethanol tolerance than $\mathrm{Pt} / \mathrm{C}$ in an alkaline electrolyte ${ }^{108}$. This approach shows the possibility to prepare advanced cathode materials for AFCs without requiring noble metal catalysts.

A series of studies by Li et al. ${ }^{109,110,111}$ investigated Pt deposited through several methods on electrospun carbon nanofibrous mats (also from PAN precursor) for DMFC applications. The carbon nanofibres improve the catalytic peak current of methanol compared to commercial $\mathrm{Pt} / \mathrm{C}^{110}$ (see Fig. 5), indicating that the $1 \mathrm{D}$ structure of the carbon mat is beneficial to the catalytic performance of the catalyst. Another approach for Pt deposition was reported by Lin et al. ${ }^{112}$ through the pre-functionalisation of the CNFs with 1-aminopyrene in order to improve $\mathrm{Pt}$ attachment. After chemical reduction, they obtained $\mathrm{PtRu}$ nanoparticles with small diameter $(3.5 \mathrm{~nm})$ and homogeneous distribution. The resultant PtRu/CNFs had high electrochemical surface area and good activity toward methanol oxidation.

Other polymers have also been used to produce carbon nanofibres. Xuyen et al. ${ }^{113}$ have prepared polyimide (PI)-based carbon nanofibres which were synthesised by the use of an electrospun poly(amic acid) (PAA) nanofibre precursor. Such a PI nanofibre mat can then be subsequently modified via hydrolysis in order to generate surface sites favourable to anchoring of Pt nanoparticles. Here the immobilisation of the Pt precursor is controlled through the degree of hydrolysis, and the size and distribution of $\mathrm{Pt}$ nanoparticles by the subsequent carbonisation step. 


\section{Cite this: DOI: $10.1039 / \mathrm{c} 0 \mathrm{xx} 00000 \mathrm{x}$}

An alternative method for the fabrication of $\mathrm{Pt} /$ carbon and $\mathrm{Pt}-\mathrm{Pd} / \mathrm{carbon}$ composite nanofibres has been described by Lin et al. ${ }^{114,}{ }^{115}$ where Pt and Pt-Pd nanoparticles were electrodeposited directly onto electrospun carbon nanofibres. In this method, the morphology and size of nanoparticles can be controlled via the deposition time. Huang et al. ${ }^{116}$ have also used electrodeposition to prepare CNF-supported bimetallic $\mathrm{Pt}_{\mathrm{x}} \mathrm{Au}_{100-\mathrm{x}}$ electrocatalysts, which showed good electrocatalytic performance for potential use in direct formic acid fuel cells.

As mentioned above, carbon is the most widely used catalyst support because of its high surface area and excellent electronic conductivity, however it can undergo chemical corrosion especially under stop/start operation conditions ${ }^{117}$ leading to carbon oxidation, according to ${ }^{118,119}$ :

$\mathrm{C}+2 \mathrm{H}_{2} \mathrm{O} \rightarrow \mathrm{CO}_{2}+4 \mathrm{H}^{+}+4 \mathrm{e}^{-}$

$\left(\mathrm{E}^{0}=0.207 \mathrm{~V}\right.$ vs. $\mathrm{NHE}$ at $\left.25^{\circ} \mathrm{C}\right)$

This leads to migration and coalescence or sintering of catalyst particles or even their detachment with a consequent loss of electrochemical surface area (ECSA) and performance ${ }^{120,121,122}$. Furthermore, platinum is considered to be involved in accelerating this oxidative process. ${ }^{123}$

\begin{tabular}{|c|c|c|c|c|c|c|}
\hline Fuel cell type & Material & $\begin{array}{c}\text { Mass } \\
\text { activity } \\
\left(\mathrm{A} \mathrm{g}^{-1}\right)\end{array}$ & $\begin{array}{c}\text { Fibre } \\
\text { diameter } \\
(\mathbf{n m})\end{array}$ & $\begin{array}{c}\text { ECSA } \\
\left(\mathbf{m}^{2} \mathbf{g}^{-1}\right)\end{array}$ & Advantages & Ref. \\
\hline \multirow{3}{*}{ DMFC } & $\mathrm{Pt}$ & 47 & $50-70$ & $3.6-6.2$ & $\begin{array}{l}\text { electrochemical activity toward } \\
\text { MOR }^{\mathrm{a}}\end{array}$ & 92 \\
\hline & $\mathrm{PtRh}$ and $\mathrm{PtRu}$ & $\begin{array}{c}355.8 \\
\text { and } \\
449.1\end{array}$ & 50 & $\mathrm{NA}^{\mathrm{b}}$ & $\begin{array}{c}\text { stability, enhancement of } \\
\text { electrocatalytic properties by } 30 \% \\
\text { relative to } \mathrm{PtRu} / \mathrm{C}\end{array}$ & 94 \\
\hline & $\begin{array}{c}\mathrm{Pd} / \mathrm{PA} 6 \\
\text { (polyamide 6) } \\
\mathrm{NF}\end{array}$ & NA & $\begin{array}{c}\text { Pd/PA6 } \\
322, \\
\text { Pd layer } 85\end{array}$ & NA & $\begin{array}{l}\text { facile and cost-effective synthesis } \\
\text { of Pd NFs }\end{array}$ & 99 \\
\hline \multirow[t]{2}{*}{$\begin{array}{l}\text { Direct cyclohexane } \\
\text { fueled PEMFC }\end{array}$} & $\mathrm{Pt}$ and PtRh & NA & $30-40$ & NA & performance in fuel cell tests & 93 \\
\hline & Pt-NP into Pt & 48.3 & $20-40$ & NA & mass activity increase by $50 \%$ & 95 \\
\hline \multirow[t]{2}{*}{ PEMFC } & & & & & & \\
\hline & $\mathrm{Pt}-\mathrm{Fe}$ & 91 & $10-20$ & 24 & $\begin{array}{l}\text { increase of specific activity } \\
\text { compared to } \mathrm{Pt} / \mathrm{C}\end{array}$ & 98 \\
\hline
\end{tabular}

Table 1. Electrospun nanofibres for fuel cell electrocatalysts.

Much effort is being devoted to developing novel catalyst supports or secondary supports, including conductive or semi-conductive oxides such as $\mathrm{TiO}_{\mathrm{x}}{ }^{124}$, 125, ${ }^{126}, \mathrm{SiO}_{2}{ }^{127}, \mathrm{MnO}_{\mathrm{x}}{ }^{128}, \mathrm{WO}_{\mathrm{x}}{ }^{129}, \mathrm{SnO}_{2}{ }^{130}$ as well as carbides $^{131}$ and nitrides ${ }^{132}$, to modify the catalyst support for PEM fuel cells and enhance the catalytic performance of the system. Metal oxides represent a very attractive alternative to conventional catalyst supports, because of their exceptional chemical stability and corrosion resistance at the potentials and $\mathrm{pH}$ of use in PEM fuel cells ${ }^{133}$. Such metal oxidesupported catalyst systems have already given promising results in terms of catalyst performance and durability $^{80}$ and also a better tolerance to methanol (in the case of $\left.\mathrm{TiO}_{\mathrm{x}} / \mathrm{C}\right)^{134}$ and $\mathrm{CO}\left(\mathrm{W}_{18} \mathrm{O}_{49}\right)^{135}$ with respect to conventional $\mathrm{Pt} / \mathrm{C}$ electrodes. It was shown that a modification of the carbon support surface with semiconducting oxides, such as titanium oxide, reduces the electrochemically induced corrosion of the catalyst $^{136}, 137,138$. Furthermore, the electrocatalytic activity is increased in comparison with $\mathrm{Pt} / \mathrm{C}$ systems due to a synergetic interaction with the metal catalyst, the so-called strong metal-support interaction $(\mathrm{SMSI})^{139}$. A challenge that has still not been fully resolved is the brittleness of ceramic nanofibres that can make them fragile and difficult to handle. Paths being followed include mechanical pressing, preparation of twisted yarns, as well as formation of 


\section{Cite this: DOI: $10.1039 / \mathrm{c0xx00000x}$}

\section{www.rsc.org/xxxxxx}

ARTICLE TYPE

composites with polymers ${ }^{140,141}$
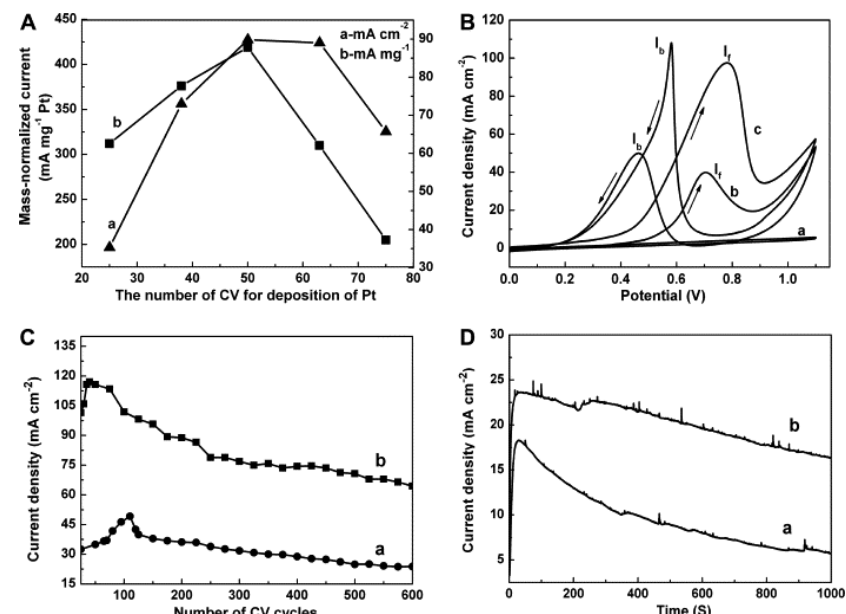

Fig. 5. (A) The plot of the peak current density of methanol oxidation on different $\mathrm{Pt} / \mathrm{CFM}$ electrodes versus the cycle number of $\mathrm{CV}$ of $\mathrm{Pt}$ deposition, the potential scan rate is $100 \mathrm{mV} \mathrm{s}^{-1}$, (B) cyclic voltammograms obtained for methanol oxidation on (a) CFM, (b) Pt/C and (c) $\mathrm{Pt} / \mathrm{CFM}$ (Pt deposited by CV with 50 cycles) electrodes with the potential scan rate of $50 \mathrm{mV} \mathrm{s}^{-1}$, (C) The plot of anodic peak current density of methanol oxidation on (a) Pt/C and (b) Pt/CFM electrode versus cycle numbers of CV with the potential scan rate of $100 \mathrm{mV} \mathrm{s}^{-1}$, (D) Chronoamperometric curves of methanol oxidation on (a) Pt/C and (b) Pt/CFM at potential of $0.45 \mathrm{~V}$. Reprinted from ref. 110 Copyright (2008), with permission from Elsevier.

Titania based materials are receiving attention as supports for PEMFC catalysts, showing excellent stability $^{142}$ and promising activity for oxygen reduction $^{143}$ as well as for methanol oxidation ${ }^{144}$. Nevertheless, the conductivity of stochiometric $\mathrm{TiO}_{2}$ is poor $\left(10^{-13} \mathrm{~S} \mathrm{~cm}^{-1} \text { at } 298 \mathrm{~K}\right)^{145}$, and doping with donor-type ions ${ }^{146,} 147$ or reducing it to nonstoichiometric compositions ${ }^{148,} 149$ are some of the possible methods used to enhance this property.

So far, only a few studies have been reported on the development of alternative FC catalyst supports elaborated by electrospinning and all of them deal with $\mathrm{TiO}_{2}$. Formo et al. reported an electrocatalytic study on the methanol oxidation reaction of electrospun anatase nanofibres decorated with $\mathrm{Pt}$ catalysts in the form of NPs or NWs prepared by polyol reduction ${ }^{150}$. The electrochemical activity and durability for the $\mathrm{Pt}$ nanowires and the $\mathrm{Pt}$ nanoparticles with a submonolayer coverage were improved compared to commercial Pt/C. Conductive titania electrospun nanofibres, obtained by $\mathrm{Nb}$ doping or $\mathrm{H}_{2}$ reduction treatment, were also evaluated as $\mathrm{Pt}$ support materials towards oxygen reduction ${ }^{151}$. Pt supported on $\mathrm{TiO}_{2}$ was more stable than Pt supported on $\mathrm{C}$ when subjected to 1000 voltammetric cycles in the range of $0.05-1.3 \mathrm{~V} v s$. RHE. $\mathrm{Nb}$ doped $\mathrm{TiO}_{2}$ showed the highest stability, retaining $60 \%$ of the ECSA after 1000 cycles while the $\mathrm{Pt} / \mathrm{C}$ catalyst only retained $20 \%$. However, the carbon-based catalyst presented the highest ORR activity due to its larger specific area and the higher electrical conductivity of the support. Very recently, Long et al. developed a deposition method of $\mathrm{Pt}$ nanoparticles on electrospun titania fibres by microwave irradiation allowing loadings as high as $40 \mathrm{wt} \%$ without agglomeration ${ }^{152}$. $\mathrm{Pt}_{30 \mathrm{w} t} \% / \mathrm{TiO}_{2}$ presented a higher activity toward methanol oxidation compared to commercial $\mathrm{Pt}_{20 \mathrm{wt} \%} / \mathrm{C}$. These electrodes were very stable after electrochemical cycling and long storage. $\mathrm{TiO}_{2}$ electrospun fibres were also used as supports for $\mathrm{Pd}$ nanoparticles for electrooxidation of glycerol ${ }^{153}$. Such $\mathrm{Pd} / \mathrm{TiO}_{2}$ nanofibres can greatly promote glycerol electrooxidation in alkaline medium. Their application for oxidation of other alcohols such as methanol, ethylene glycol, and 1,2-propanediol was also demonstrated.

One of the greatest challenges in preparing electrospun $\mathrm{TiO}_{2}$-based cathodes for PEMFC is increasing their catalytic activity by improving the dispersion of Pt nanocatalysts. With that aim, new strategies are being developed such as photodeposition ${ }^{154}$ or an in situ electrospinning-based method (see Fig. 6) ${ }^{89}$ leading to Pt loaded conductive nanofibres with potential application as fuel cell electrodes. 


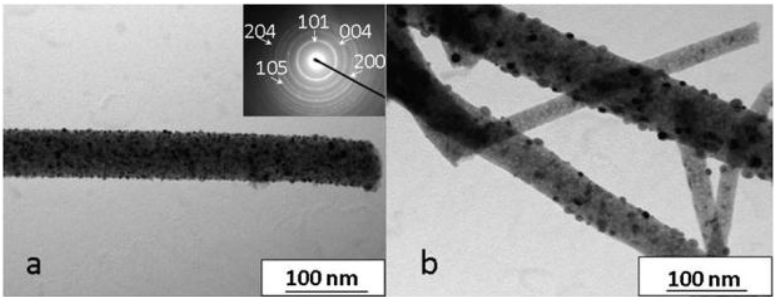

Fig. 6. Pt loaded $\mathrm{Nb}$-doped $\mathrm{TiO}_{2}$ electrospun nanofibres ${ }^{89}$.

Concerning other non carbonaceous support materials for low temperature FC prepared by electrospinning, García-Márquez et al. have recently elaborated chromium nitride/carbide nanocomposite ceramic nanofibres ${ }^{155}$. CrN being suggested as a suitable nonnoble electrocatalyst for cost effective fuel cells ${ }^{156}$, the electrocatalytic properties of the pure fibre composites for the ORR were studied. Compared to commercial carbon-based electrodes, they showed a higher catalytic activity, but a lower current density due to lower surface area.

Few studies concerning electrospun electrodes for solid oxide fuel cells (SOFCs) have been reported as yet. The fabrication of ceramic components, such as yttria-stablized zirconia (YSZ) and gadolinia-doped ceria (GDC) in nanofibrillar structures is described ${ }^{157}$, ${ }^{158}$, and recently, Ni/YSZ nanofibres, prepared by electrospinning and electroless plating, have been tested as the anodes in a commercial half cell and compared with a cell provided with conventional ballmilled powders of the same material ${ }^{159}$. The peak power density for the cell with the fibre-derived anode was twice that with the powder-derived anode. This result illustrates the effect of the 1D morphology on the enhancement of ionic and electric transfer at the three-phase-boundary sites, and then of the overall performance.Electrospinning has also been recently used to prepare high porosity, surface area and conductivity $\mathrm{Ba}_{0.5} \mathrm{Sr}_{0.5} \mathrm{Fe}_{0.8} \mathrm{Cu}_{0.2} \mathrm{O}_{3-\delta}$ fibres used as cathode material for an intermediate-temperature proton-conducting ceramic fuel cell ${ }^{160}$..

Finally, carbon nanofibre mats produced by (gasassisted) electrospinning and solution blowing ${ }^{161}$ were used as electrodes in microbial fuel cells leading to high anode current densities ${ }^{162}$.

Table 2. Electrospun nanofibres for fuel cell electrodes.

\begin{tabular}{|c|c|c|c|c|c|c|}
\hline FC type & Material & $\begin{array}{l}\text { Fibre diameter } \\
\qquad(\mathbf{n m})\end{array}$ & $\begin{array}{c}\text { Catalyst } \\
\text { particle size } \\
(\mathbf{n m})\end{array}$ & $\underset{\left(\mathbf{m}^{2} \mathbf{g}^{-1}\right)}{\text { BET }}$ & $\begin{array}{l}\text { ECSA } \\
\left(\mathbf{m}^{2} \mathbf{g}^{-1}\right)\end{array}$ & Ref. \\
\hline \multirow[t]{5}{*}{$\mathrm{AFC}$} & $\mathrm{FeCo} / \mathrm{CNFs}$ & $100-200$ & ${ }^{\mathrm{a}} \mathrm{NA}$ & NA & NA & 108 \\
\hline & $\mathrm{Pt} / \mathrm{C}-\mathrm{CFM}^{\mathrm{b}}$ & $130-170$ & commercial & 23 & NA & 109 \\
\hline & $\mathrm{Pt} / \mathrm{CFM}$ & $130-170$ & $50-200$ & 7 & NA & 110 \\
\hline & $\mathrm{PtRu} / 1$-aminopyrene-CNFs & $100-300$ & $3.1-3.6$ & NA & 32.7 & 112 \\
\hline & electrodeposited Pt/CNFs & $200-300$ & 20 & NA & $\begin{array}{c}0.37-0.89 \\
\mathrm{~cm}^{2 \mathrm{c}}\end{array}$ & 114 \\
\hline \multirow[t]{3}{*}{ DMFC } & $\begin{array}{c}\mathrm{Pt} / \mathrm{Au}-\mathrm{PAN} \text { and } \mathrm{Pt} / \mathrm{C} / \mathrm{Au}- \\
\text { PAN }\end{array}$ & 740 & $2-6$ & NA & $\begin{array}{l}39.8 \text { and } \\
30.6\end{array}$ & 111 \\
\hline & $\begin{array}{c}\mathrm{Pt} / \text { polyimide-based CFM } \\
\mathrm{Pt} / \mathrm{CFM}\end{array}$ & $\approx 200$ & $\begin{array}{c}<3 \\
5\end{array}$ & $\begin{array}{l}\text { NA } \\
\text { NA }\end{array}$ & $\begin{array}{l}\text { NA } \\
\text { NA }\end{array}$ & $\begin{array}{l}113 \\
163\end{array}$ \\
\hline & $\mathrm{Pt}(\mathrm{NP}$ and $\mathrm{NW}) / \mathrm{TiO}_{2}$ & $150-400$ & $\begin{array}{c}2-5 / \\
5-7 \times 50 / 125\end{array}$ & NA & $\begin{array}{l}56.2-16 / \\
17.6-16\end{array}$ & 150 \\
\hline DAFC & $\begin{array}{c}\mathrm{Pt} / \mathrm{TiO}_{2} \\
\mathrm{Pd} \text { layer/ } \mathrm{TiO}_{2}\end{array}$ & $\begin{array}{c}30-60 \\
115\end{array}$ & $\begin{array}{c}5 \\
61 \text { (thickness) }\end{array}$ & $\begin{array}{l}\text { NA } \\
\text { NA }\end{array}$ & $\begin{array}{l}\text { NA } \\
\text { NA }\end{array}$ & $\begin{array}{l}152 \\
153\end{array}$ \\
\hline \multirow[t]{3}{*}{ DFAFC $^{\mathrm{d}}$} & $\begin{array}{l}\text { Electrodeposited } \mathrm{Pt}_{\mathrm{x}} \mathrm{Au}_{100-} \\
{ }_{\mathrm{x}} / \mathrm{CNF}\end{array}$ & $\approx 700$ & 118 & NA & NA & 116 \\
\hline & $\mathrm{Pt} / \mathrm{CNF}$ acid & 250 & $2.6-2.9$ & 302 & 74.5 & 105 \\
\hline & electrodeposited PtPd/CNFs & $\approx 250-400$ & $29-64$ & NA & NA & 115 \\
\hline \multirow{2}{*}{ PEMFC } & $\mathrm{Pt} / \mathrm{Nb}$ doped $\mathrm{TiO}_{2}$ & $50-100$ & 5 & NA & 5.0 & 151 \\
\hline & $\mathrm{CrN}-\mathrm{Cr}_{3} \mathrm{C}_{2}$ & $200-500$ & NA & $25-110$ & NA & 155 \\
\hline SOFC & $\mathrm{Ni} / \mathrm{YSZ}$ & 300 & NA & NA & NA & 159 \\
\hline Microbial FC & CNF based biofilms & $\approx 1000$ & NA & NA & NA & 162 \\
\hline
\end{tabular}

${ }^{\mathrm{a}} \mathrm{NA}=$ data not available. ${ }^{\mathrm{b}} \mathrm{CFM}=$ carbon fibre mat. ${ }^{\mathrm{c}}$ Mass not reported. ${ }^{\mathrm{d}} \mathrm{DFAFC}=$ direct formic acid fuel cell. 


\section{Cite this: DOI: $10.1039 / \mathrm{c} 0 \mathrm{xx} 00000 \mathrm{x}$}

\section{3.a.3. Electrolyte membrane}

Since electrospinning is such a versatile technique for producing nanofibre mats, it is being utilised for the development of composite fuel cell membranes with the aim of modifying the morphology and improving the mechanical properties. In the literature there have been two approaches in this particular aspect of electrospinning. The first involves electrospinning a non-conductive or less conductive polymer into a porous matrix, which acts as mechanical reinforcement when the pores are filled with a highly proton conducting component. An overview of the studies utilising this approach is listed in Table 3, with perfluorosulfonic acid (PFSA) ionomers such as Nafion ${ }^{\circledR}$ being the most commonly used polymer. In general, the matrix polymer is chosen so as to improve the mechanical or barrier properties (e.g. to reduce methanol crossover) of the composite membrane.

Table 3. Overview of reinforced composite proton exchange membranes using an electrospun matrix

\begin{tabular}{|c|c|c|c|c|}
\hline Matrix Polymer & Filler Polymer & Details & $\begin{array}{c}\text { Proton } \\
\text { Conductivity } \\
\left(\mathrm{mS} \mathrm{cm} \mathbf{c m}^{-1}\right)\end{array}$ & Ref. \\
\hline Poly(vinyl alcohol) & Nafion $^{\circledR}$ & $\begin{array}{l}\text { CTAB used to facilitate } \\
\text { electrospinning; PVA matrix } \\
\text { crosslinked by treatment with } \\
\text { glutaraldehyde and sulfonated }\end{array}$ & $\begin{array}{c}22\left(70^{\circ} \mathrm{C}, 100 \%\right. \\
\left.\mathrm{RH}^{*}\right)\end{array}$ & $\begin{array}{r}164, \\
165\end{array}$ \\
\hline Poly(vinyl alcohol) & Nafion $^{\circledR}$ & $\begin{array}{l}\text { PVA matrix crosslinked by treating } \\
\text { with glutaraldehyde }\end{array}$ & $11\left(70^{\circ} \mathrm{C}, 95 \% \mathrm{RH}\right)$ & $\begin{array}{l}166, \\
167\end{array}$ \\
\hline Polyvinylidene fluoride & Nafion $^{\circledR}$ & $\begin{array}{l}\text { PVdF electrospun from } 1 / 1 \text { Acetone/ } \\
\text { DMAc }\end{array}$ & $2\left(65^{\circ} \mathrm{C}\right.$, hydrated $)$ & 168 \\
\hline Sulfonated polyethersulfone & Nafion $^{\circledR}$ & $\begin{array}{l}\text { excess Nafion }{ }^{\circledR} \text { used to form a dense } \\
\text { layer on one or both sides of the } \\
\text { pore-filled membrane }\end{array}$ & $\begin{array}{c}\sim 85(\mathrm{RT}, 100 \% \\
\mathrm{RH})\end{array}$ & $\begin{array}{l}169, \\
170\end{array}$ \\
\hline $\begin{array}{l}\text { Sulfonated random } \\
\text { copolyimide }\end{array}$ & $\begin{array}{l}\text { Sulfonated } \\
\text { polyimide }\end{array}$ & $\begin{array}{l}\text { proton conductivity higher compared } \\
\text { to blend membrane from } \\
\text { conventional (solution) methods }\end{array}$ & $\begin{array}{l}\text { Up to } 370(90 / 10 \\
\text { blend at } 80^{\circ} \mathrm{C} \text { and } \\
\quad 98 \% \mathrm{RH})\end{array}$ & 171 \\
\hline $\begin{array}{c}\text { Crosslinked } \\
\text { bromomethylated sulfonated } \\
\text { polyphenylene oxide } \\
\text { (BPPO) }\end{array}$ & $\begin{array}{l}\text { Sulfonated Poly }(2,6- \\
\text { dimethyl-1,4- } \\
\text { phenylene oxide) } \\
\text { (SPPO) }\end{array}$ & $\begin{array}{l}\text { BPPO electrospun from NMP and } \\
\text { crosslinked by treating with } \mathrm{NH}_{3}\end{array}$ & $\begin{array}{c}30-80(\mathrm{RT}, 100 \% \\
\mathrm{RH})\end{array}$ & 172 \\
\hline
\end{tabular}

${ }^{*}$ Relative humidity (\%)

Alternatively, a highly proton conducting matrix is electrospun into a porous fibre mat and this is then reinforced with a secondary polymer to provide mechanical stability. Most studies have focused on the electrospinning of PFSAs, but other sulfonated polymers such as poly(ether ether ketone) and poly(arylene ether sulfone) have also been electrospun into fibres. An overview of the publications in this area is given in Table 4.

In all cases, conductivity largely depends on the volume fraction of the proton conductive component, with a large percentage ratio of ionomer needed for high proton conductivity. In some studies, proton conductivity is reduced significantly due to the nonconductive component, however other properties of the membrane, such as mechanical and hydrolytic stability ${ }^{172}$ or reduced methanol permeability ${ }^{164,168,169}$ (for DMFC) are significantly improved. In the case of DMFC, despite their lower proton conductivity, electrospun composite membranes show comparable fuel cell performance to Nafion ${ }^{\circledR}$ due to the reduced methanol crossover and lower membrane thickness made possible by improved mechanical properties. 
Cite this: DOI: 10.1039/c0xx00000x

www.rsc.org/xxxxxx

ARTICLE TYPE

Table 4. Overview of electrospun proton conducting polymers for fuel cell membrane applications.

\begin{tabular}{|c|c|c|c|c|c|}
\hline Polymer & Solvent & $\begin{array}{c}\text { Additives/Carrier } \\
\text { Polymer }\end{array}$ & Details / Post Treatment & $\begin{array}{c}\text { Proton } \\
\text { Conductivity } \\
\left(\mathrm{mS} \mathrm{cm} \mathbf{c m}^{-1}\right)\end{array}$ & Ref. \\
\hline Nafion $^{\circledR}$ & $\mathrm{IPA} / \mathrm{H}_{2} \mathrm{O}$ & $12 \mathrm{wt} \%$ PAA & PAA $M_{w} 4.5 \times 10^{5}$ & NA & 173 \\
\hline Nafion $^{\circledR}$ & $\mathrm{IPA} / \mathrm{H}_{2} \mathrm{O}$ & $5 \mathrm{wt} \%$ PVA or PEO & $\begin{array}{c}\text { PEO } \mathrm{M}_{\mathrm{w}} 2 \times 10^{5} ; \mathrm{PVA} \\
\mathrm{M}_{\mathrm{w}} 1.1 \times 10^{5}\end{array}$ & $8.7-16$ & 174 \\
\hline Nafion $^{\circledR}$ & $\mathrm{MeOH}$ & $\begin{array}{c}0.1 \mathrm{wt} \% \text { high molecular } \\
\text { weight } \mathrm{PEO}\end{array}$ & PEO $\mathrm{M}_{\mathrm{w}} 8 \times 10^{6}$ & $\begin{array}{l}1500 \text { ( single fibre } \\
\text { of } 400 \mathrm{~nm} \\
\text { diameter, } \\
\left.30^{\circ} \mathrm{C} ; 90 \% \mathrm{RH}\right)\end{array}$ & 175 \\
\hline Nafion $^{\circledR}$ & $\mathrm{EtOH}$ & $\begin{array}{c}\text { PVP (1:2 PFSA/PVP wt } \\
\text { ratio) }\end{array}$ & none & c.a. $8.5 \times 10^{-3}$ & 176 \\
\hline Nafion $^{\circledR}$ & $\begin{array}{c}2 / 1 \\
\text { Alcohols } / \mathrm{H}_{2} \mathrm{O}\end{array}$ & PEO & $\begin{array}{c}\text { PEO } \mathrm{M}_{\mathrm{w}} 2 \times 10^{5}, 3 \times 10^{5} \\
\text { and } 6 \times 10^{5}\end{array}$ & NA & 177 \\
\hline Nafion $^{\circledR}$ & $\mathrm{H}_{2} \mathrm{O}$ & $\begin{array}{l}\text { PEO, PVA, or PVP (very } \\
\text { high ratio to PFSA) }\end{array}$ & large fibres $(0.5-2 \mu \mathrm{m})$ & NA & 178 \\
\hline $\begin{array}{l}3 \mathrm{M} \\
\text { perfluorosulfonic } \\
\text { acid polymer }\end{array}$ & $\begin{array}{c}2 / 1 \\
\text { Propanol/ } \mathrm{H}_{2} \mathrm{O}\end{array}$ & $\operatorname{PEO}\left(\mathrm{M}_{\mathrm{w}} 2 \times 10^{5}\right)$ & $\begin{array}{c}\text { annealing, densification by } \\
\text { pressing, and pore-filling } \\
\text { with a resin }\end{array}$ & $\begin{array}{l}55\left(80^{\circ} \mathrm{C}\right. \\
50 \% \mathrm{RH})\end{array}$ & 179 \\
\hline $\begin{array}{l}3 \mathrm{M} \\
\text { perfluorosulfonic } \\
\text { acid polymer }\end{array}$ & $\begin{array}{c}2 / 1 \\
\text { Propanol/ } / \mathrm{H}_{2} \mathrm{O}\end{array}$ & $\begin{array}{c}\text { PAA, sulfonated polyhedral } \\
\text { oligomeric silsesquioxane } \\
\text { (sPOSS) }\end{array}$ & $\begin{array}{l}\text { mat densified, annealed, } \\
\text { and impregnated with a } \\
\text { resin to form dense } \\
\text { membrane }\end{array}$ & $\begin{array}{c}498(35 \% \text { sPOSS, } \\
\left.120^{\circ} \mathrm{C} 90 \% \mathrm{RH}\right)\end{array}$ & 180 \\
\hline $\begin{array}{l}\text { Polymerised Ionic } \\
\text { Liquid }\end{array}$ & $\begin{array}{c}\text { 3/1 } \\
\mathrm{MeCN} / \mathrm{DMF}\end{array}$ & poly $\left(\mathrm{MEBIm}-\mathrm{BF}_{4}\right)$, PAA & $\begin{array}{l}\text { solutions of poly(MEBIm- } \\
\mathrm{BF}_{4} \text { ) was mixed with } \\
\text { Nafion/PAA for } \\
\text { electrospinning }\end{array}$ & $\begin{array}{c}7.1 \times 10^{-4}\left(30^{\circ} \mathrm{C}\right. \\
10 \% \mathrm{RH})\end{array}$ & 181 \\
\hline $\begin{array}{l}\text { Sulfonated } \\
\text { poly(ether ether } \\
\text { ketone ketone) }\end{array}$ & DMF & none & $\begin{array}{l}\text { membranes dried at } 80^{\circ} \mathrm{C} \\
\text { for } 24 \mathrm{~h}\end{array}$ & $\begin{array}{l}37 \text { (spherical bead } \\
\text { morphology at } \\
\left.25^{\circ} \mathrm{C}, 100 \% \mathrm{RH}\right)\end{array}$ & 182 \\
\hline $\begin{array}{l}\text { Sulfonated } \\
\text { poly(ether ether } \\
\text { ketone) }\end{array}$ & DMAc & none & $\begin{array}{l}\text { densification by pressing } \\
\text { and welding by exposure } \\
\text { to solvent vapours, and } \\
\text { pore filling with an inert } \\
\text { resin }\end{array}$ & $\begin{array}{c}41\left(25^{\circ} \mathrm{C} 100 \%\right. \\
\mathrm{RH})\end{array}$ & 183 \\
\hline $\begin{array}{c}\text { Sulfonated } \\
\text { poly(arylene ether } \\
\text { sulfone })\end{array}$ & DMAc & none & $\begin{array}{c}\text { annealing, pressing, and } \\
\text { welding of fibres by } \\
\text { exposure to solvent } \\
\text { vapours }\end{array}$ & $\begin{array}{c}86(70 \% \text { fibre } \\
\text { volume fraction, } \\
\left.25^{\circ} \mathrm{C}, 100 \% \mathrm{RH}\right)\end{array}$ & 184 \\
\hline $\begin{array}{c}\text { Sulfonated } \\
\text { poly(arylene ether } \\
\text { sulfone) }\end{array}$ & DMAc & $\begin{array}{c}\text { sulfonated polyhedral } \\
\text { oligomeric silsesquioxane } \\
\text { (sPOSS) }\end{array}$ & $\begin{array}{l}\text { mat densified, annealed, } \\
\text { and impregnated with a } \\
\text { resin to form dense } \\
\text { membrane }\end{array}$ & $\begin{array}{l}94\left(30^{\circ} \mathrm{C},\right. \\
80 \% \mathrm{RH})\end{array}$ & $\begin{array}{l}185 \\
186\end{array}$ \\
\hline $\begin{array}{l}\text { Sulfonated co- } \\
\text { polyimide }\end{array}$ & DMF & none & $\begin{array}{l}\text { pore filling with more } \\
\text { highly sulfonated PI }\end{array}$ & $\begin{array}{l}\sim 100\left(80^{\circ} \mathrm{C}\right. \\
95 \% \mathrm{RH})\end{array}$ & 187 \\
\hline $\begin{array}{l}\text { Sulfonated } \\
\text { polystyrene }\end{array}$ & DMF & none & $\begin{array}{c}\text { fibres obtained at high } \\
\text { concentration and PS } \\
\text { molecular weight }\left(\mathrm{M}_{\mathrm{w}} 5 \times\right. \\
\left.10^{5}\right)\end{array}$ & NA & 188 \\
\hline $\begin{array}{l}\text { Polyvinylidene } \\
\text { fluoride }\end{array}$ & DMAc & $\begin{array}{l}\text { Phosphotungstic acid } \\
\text { (PWA, up to } 12.8 \mathrm{wt} \% \text { ) }\end{array}$ & $\mathrm{PVdF}_{\mathrm{w}} 2.2 \times 10^{5}$ & $\begin{array}{c}\sim 0.4(6.7 \% \text { PWA, } \\
\left.60^{\circ} \mathrm{C}, 100 \% \mathrm{RH}\right)\end{array}$ & 189 \\
\hline Aquivion $^{\mathrm{TM}}$ & DMAc & $\operatorname{PEO}\left(\mathrm{M}_{\mathrm{w}} 1 \times 10^{6}\right)$ & $\begin{array}{c}\text { annealing and } \\
\text { densification by pressing }\end{array}$ & $\begin{array}{c}66\left(120^{\circ} \mathrm{C}\right. \\
95 \% \mathrm{RH})\end{array}$ & 190 \\
\hline Sulfated $\mathrm{ZrO}_{2}$ & IPA & $\begin{array}{l}\text { PVP, poly(2-acrylamido-2- } \\
\text { methylpropanesulfonic } \\
\text { acid) (pAMPS) }\end{array}$ & $\begin{array}{l}\text { mat densified, heat treated, } \\
\text { sulfonated and calcined to } \\
\text { form } \mathrm{S}-\mathrm{ZrO}_{2} \text { membranes } \\
\text { and pore-filled with }\end{array}$ & $\begin{array}{c}240\left(100^{\circ} \mathrm{C}, 80 \%\right. \\
\mathrm{RH})\end{array}$ & 191 \\
\hline
\end{tabular}


$\mathrm{p}$ (AMPS)

Electrospinning also introduces changes in the membrane morphology compared to conventional processing methods such as solution casting. Li et $a l .{ }^{182}$ reported the electrospinning and electrospraying of sulfonated poly(ether ether ketone ketone) (SPEEKK), and found that the electrospun/sprayed membrane shows a more distinct SAXS ionomer peak, shifted to lower angles, compared to a cast membrane, indicating better phase separation and larger proton transport channels. In their study, the highest conductivity was obtained with a spherical rather than fibrous morphology, suggesting that proton transport occurs on the interface between particles rather than within the polymer itself. Since this first study, however, several others ${ }^{175}, 176,187$ of single proton conducting nanofibres show greater apparent conductivity within the nanofibre than of a cast film. This is attributed to the alignment of the ionic aggregates that is believed to occur during electrospinning. Dong et al. ${ }^{175}$ found that the proton conductivity increases with decreasing fibre diameter which suggests that the confinement of the nanofibre size may assist in aligning the ionic domains in the longitudinal direction. Furthermore, X-ray scattering at high relative humidity indicates that the ionic aggregates in the fibres are anisotropic and are oriented in the direction of the axis. Similarly, a study by Tamura et al. ${ }^{187}$ on sulfonated polyimide nanofibres reported a much higher apparent conductivity of single nanofibres compared to cast films, with greater conductivity along the fibres than in the perpendicular direction of their membrane. The study by Pan et al. ${ }^{176}$ also examined the possibility of using such single fibres in a micro-fuel cell, and a performance significantly higher than that of a conventional fuel cells was described.

In the case of PFSA, a carrier polymer is generally required to enable electrospinning due to aggregation of the PFSA chains. Electrospinning of Nafion ${ }^{\circledR}$ was first reported by Laforgue et al. ${ }^{174}$ using PVA or PEO as the carrier polymer. Further studies have used PAA, PVP, or PEO, with comparable results. The presence of carrier polymer is detrimental to proton conductivity, especially when significant quantities are present, however more recent studies have minimised the carrier polymer content (or removed it through washing ${ }^{179}$ ) and show comparable proton conductivities with cast films despite lower PFSA volume fraction in the electrospun membranes. Choi et $a l{ }^{186}$ have incorporated sulfonated polyhedral oligomeric silsesquioxane (sPOSS) in order to increase the concentration of sulfonic acid groups, and thus were able to increase the proton conductivity of their composite membrane significantly beyond that of Nafion ${ }^{\circledR}$. Some studies have also used PFSAs with shorter side chain than Nafion ${ }^{\circledR}$, which allows for lower EW ionomers to be used. When fibres of equal PFSA/carrier polymer ratios are compared, electrospinning with shorter side chain PFSAs was found to give smaller average fibre diameter in the case of $3 \mathrm{M}$ PFSA ${ }^{177,179}$, and also narrower fibre size distribution in the case of Aquivion ${ }^{\text {TM }} 190$ (see Fig.7).
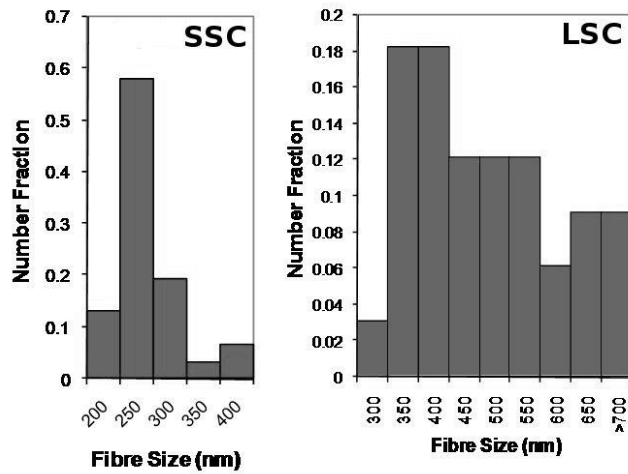

Fig. 7. Fibre size distribution of electrospun long (LSC Nafion $^{\circledR}$ )-side chain and short-side chain (SSC Aquivion ${ }^{\mathrm{TM}}$ ) PFSA. $^{190}$

Some investigations have produced a composite proton exchange membrane by filling the pores of the electrospun matrix with a curable, inert polymer for mechanical reinforcement. Studies published by Pintauro et al. ${ }^{179,} 180,184,185,186$ used UV-curable polyurethane resin in an electrospun $\mathrm{Nafion}^{\circledR}$ or $3 \mathrm{M}$ PFSA matrix, and found that the proton conductivity of the composite membrane compares favourably to cast membranes, while the composite allows for lower swelling and improved mechanical properties (see Fig. 8). A different approach was reported by Takemori et $a l .{ }^{171}$ where an electrospun sulfonated random copolyimide was pore-filled with a more highly sulfonated polyimide. The nanofibre composite membrane shows better proton conductivity and stability compared to a blend membrane of the same materials, indicating the benefits of the interpenetrating, nanofibre network morphology. 


\section{Cite this: DOI: $10.1039 / \mathrm{c} 0 \mathrm{xx} 00000 \mathrm{x}$}

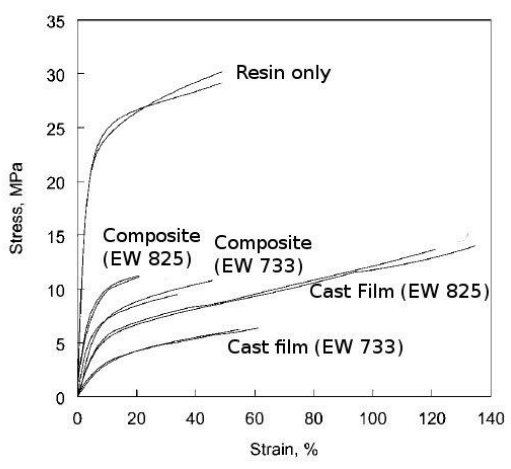

Fig. 8. Stress strain curves comparison of cast films and composite nanofibre membranes of $3 \mathrm{M}$ PFSA and a commercial UV-curable resin. Reprinted from ref. 179, Copyright (2010), with permission from the Royal Society of Chemistry.

A variant of this approach using $\mathrm{ZrO}_{2}$ nanofibres was reported by Yao et al. ${ }^{191}$, who synthesised nanofibre mats of $\mathrm{ZrO}_{2}$ which were then sulfonated by immersion in dilute sulfuric acid. After calcination, These are referred to as dye-sensitised solar cells (DSCs) due to their used of a dye photosensitiser, and they provide a technically and economically attractive alternative because of their low cost, light weight, and high power conversion efficiency ${ }^{193}$. In contrast to the conventional silicon systems, where the semiconductor plays the role of absorbing light as well as the charge carrier and transport, in DSCs the two functions are separated. In DSCs, the photosensitiser absorbs light to generate excited electron-hole pairs that then undergo interfacial charge separation.

A typical DSC consists of a photoanode and a counter electrode separated by an electrolyte containing an iodide $\left(\mathrm{I}^{-}\right)$/triiodide $\left(\mathrm{I}_{3}^{-}\right)$redox couple. Usually the photoanode is a transparent conducting oxide (TCO) coated with a film of a wide bandgap semiconductor (typically $\mathrm{TiO}_{2}$ nanoparticles) and the counter electrode is a TCO coated with a thin layer of platinum. Light is absorbed by the photosensitiser (a charge-transfer dye) linked to the oxide surface. The photo-electrons are then injected from the dye into the conduction band of the semiconductor and finally transported to the counter electrode through an external circuit. Here, the electrons are transferred to the electrolyte that carries them back to the dye molecule through a redox process, completing the circuit. Unlike conventional silicon solar cells, the use of dye-sensitisers with broad absorption bands in combination with nanostructured oxides allows DSCs to harvest a large fraction of sunlight.

So far, conversion efficiencies of $11 \%{ }^{194,}, 195$ have been obtained, but the theoretical limit of $30 \%$ for a single junction semiconductor photovoltaic device ${ }^{196}$ the $\mathrm{S}-\mathrm{ZrO} \mathrm{O}_{2}$ mats were impregnated with crosslinked poly(2-acrylamido-2-methylpropanesulfonic acid) (pAMPS) to fabricate a composite membrane having high IEC and in which the authors suggest the existence of a continuous conducting pathway along the organic-inorganic interface.

\section{3.b. Electrospun materials for dye-sensitised solar cells}

Solar cells convert light into electricity and are based on the charge separation at an interface of two materials of different conduction bands. They have been dominated for the most part by inorganic solidstate p-n junction devices, usually Si-based, with high performance but very high material and production costs. Since its first discovery in 1991, a third generation of photovoltaic devices has emerged ${ }^{192}$.

remains far from being reached. One of the strategies to improve these devices is the introduction of new material morphologies, which sparks the recent interest in the integration of electrospun materials in DSCs in relation to all the components: photoanodes, counter electrodes and electrolytes. The effect and benefits of the 1D morphology on the obtained performances compared to the conventionally prepared devices is discussed in the following paragraphs and summarised in the Tables 5 and 6.

\section{3.b.1. Photoanodes}

There are two main requirements for the optimisation of DSC photoanodes which would lead to optimal light-to-electricity conversion efficiencies.

Firstly, charge transport must be enhanced while minimising charge recombination ${ }^{197}$, which can be achieved by controlling the morphology, porosity and crystallinity of the photoanode material as these properties strongly influence the charge transport and recombination processes. For instance, electron transport in widely used mesoporous titania nanoparticle-based photoelectrodes depends on surface states and particle morphology as well as on interparticle connectivity. Recently, the use of onedimensional (1D) nanostructured materials in DSC, such as nanotubes, nanorods, nanobelts, nanowires and nanofibres, has been investigated ${ }^{198,199,200,201}$. 1D morphology shows better electron transport properties compared to conventional NP-based systems with disordered geometrical structures and interfacial interference in electron transport ${ }^{202}$. Indeed, in 


\section{Cite this: DOI: $10.1039 / \mathrm{c0xx00000x}$}

monodimensional nanostructures (without exciton-like trap states ${ }^{203}$ ) electron transport is faster as such structures present lower grain boundaries due to their interconnectivity and high surface areas. The direct electrical pathways provided by the NFs ensure the rapid collection of charge carriers generated throughout the device.

Another requirement is to maximise the light harvesting properties of the device. Thus, photoanodes should possess a large surface area and high porosity in order to anchor the maximum amount of dye sensitisers $^{206}$ (or quantum dots ${ }^{204}$ ), in which regard the 1D geometry of NFs gives promising results.

Furthermore, nanofibres provide an open structure which allows better pore-filling with the electrolyte compared to conventional NP-based electrodes. Such infiltration of a viscous electrolyte into a fibre network improves the contact with the semiconductor and helps the regeneration of oxidized dyes, leading to enhanced energy conversion efficiency ${ }^{205}$.

In this context, several recent studies describe 1D photoanode materials (mainly $\mathrm{TiO}_{2}$ anatase) obtained by electrospinning (see Table 5). In order to further increase the dye loading and the overall efficiency of the solar cell, the electrospun nanofibres have also been shortened into nanorods (by mechanical pressure, grinding or ultrasonic bath) and DSCs prepared by using these rods alone or in combination with nanofibres and/or nanoparticles. One of the issues to be addressed for the electrospun fibre based DSCs is the poor adhesion of nanofibrous materials to conductive substrates. In order to solve this key problem, several approaches have been used and will be discussed here.

Table 5. Electrospun fibres for DSC photoanodes and the resulting photovoltaic parameters* obtained under air-mass (AM) 1.5 and $100 \mathrm{~mW}$ $\mathrm{cm}^{-2}$ of light intensity.

\begin{tabular}{|c|c|c|c|c|c|c|c|}
\hline Material & $\begin{array}{c}\text { Fibre diameter } \\
(\mathbf{n m})\end{array}$ & Dye & $\mathbf{V}_{\text {oc }}(\mathbf{V})$ & $\begin{array}{c}\mathbf{J}_{\mathrm{sc}} \\
\left(\mathrm{mA} \mathrm{cm} \mathbf{~ c m}^{-2}\right)\end{array}$ & FF & $\eta(\%)$ & Ref. \\
\hline $\mathrm{TiO}_{2}$ (anatase) & $150-700$ & N3 & $\begin{array}{c}0.738- \\
0.849\end{array}$ & $3.60-9.88$ & $0.45-0.51$ & $1.34-4.14$ & 206 \\
\hline $\mathrm{TiO}_{2}$ (anatase) & 150 & N3 & 0.78 & 9.45 & 0.57 & 4.2 & 207 \\
\hline $\begin{array}{c}\mathrm{TiO}_{2} \text { (anatase } \\
\text { + rutile } \\
\text { crystals) }\end{array}$ & $\approx 400-800$ & N3 & $0.77-0.78$ & $\begin{array}{l}10.52- \\
11.24\end{array}$ & $0.56-0.58$ & $4.60-5.02$ & 210 \\
\hline $\mathrm{TiO}_{2}$ (anatase) & $\begin{array}{c}\approx 300 \\
\text { NR } 15 \times 60-100\end{array}$ & N3 & 0.70 & 14.77 & 0.60 & 6.2 & $\begin{array}{l}\text { Erreur ! } \\
\text { Signet non } \\
\text { défini. }\end{array}$ \\
\hline $\begin{array}{c}\mathrm{TiO}_{2} \text { (anatase) } \\
\mathrm{NFs}+\mathrm{NPs}\end{array}$ & 250 & N719 & $0.64-0.71$ & $15.9-22.4$ & $0.66-0.72$ & $7.10-10.3$ & 209 \\
\hline $\begin{array}{c}\mathrm{TiO}_{2} \text { (anatase) } \\
\mathrm{NRs}+\mathrm{NPs}\end{array}$ & $100-200$ & N719 & $0.71-0.73$ & $16.4-19.3$ & $0.61-0.64$ & $7.27-8.70$ & 208 \\
\hline $\begin{array}{l}\mathrm{TiO}_{2} \text { (anatase) } \\
\text { aligned } \mathrm{NWs}\end{array}$ & 100 & N719 & 0.78 & 5.71 & 0.64 & 2.87 & 212 \\
\hline $\mathrm{TiO}_{2}$ (anatase) & $80-100$ & $\begin{array}{c}\mathrm{QD} \\
(\mathrm{CdS} / \mathrm{CdSe})\end{array}$ & $0.33-0.69$ & $1.93-9.74$ & $0.31-0.48$ & $0.31-2.69$ & $\begin{array}{l}\text { Erreur ! } \\
\text { Signet non } \\
\text { défini. }\end{array}$ \\
\hline $\begin{array}{c}\mathrm{Nb} \text { doped } \\
\mathrm{TiO}_{2} \text { (anatase) }\end{array}$ & 150 & D131 & NA & $9.74-10.0$ & NA & NA & 213 \\
\hline $\mathrm{TiO}_{2}$ (rutile) & $100-200 \mathrm{NRs}$ & N3 & $\begin{array}{l}0.748- \\
0.815\end{array}$ & $\begin{array}{l}12.14- \\
12.37\end{array}$ & $0.45-.47$ & $4.17-4.56$ & 211 \\
\hline $\mathrm{ZnO}$ & $200-500$ & N719 & 0.60 & 3.58 & 0.62 & 1.34 & 217 \\
\hline $\mathrm{ZnO}$ & NA & N719 & $0.57-0.63$ & $4.58-9.14$ & $0.57-0.66$ & $1.77-3.02$ & 218 \\
\hline $\mathrm{Al}$ doped $\mathrm{ZnO}$ & $40-160$ & N719 & 0.33 & $6.24-6.34$ & 0.26 & $0.54-0.55$ & 219 \\
\hline $\mathrm{SnO}_{2} / \mathrm{ZnO}$ & NA & D149 & 0.57 & 2.99 & 0.59 & 1.01 & 220 \\
\hline $\begin{array}{c}\mathrm{ZnO} \mathrm{NWs} / \mathrm{C} \\
\mathrm{NFs}\end{array}$ & $50 / 1160$ & black dye & $0.17-0.35$ & $2.60-11.2$ & $0.25-0.28$ & $0.1-1.1$ & 221 \\
\hline ITO & 200 & N719 & $0.64-0.65$ & $9.97-10.20$ & $0.57-0.59$ & $3.65-3.97$ & 222 \\
\hline
\end{tabular}

"Power conversion efficiency of photovoltaic cells is given by: $\eta=\mathrm{FF} \times V_{\mathrm{oc}} \times J_{\mathrm{sc}} / P_{\text {in }}$ with FF $=V_{\max } \times J_{\max } / V_{\mathrm{oc}} \times J_{\mathrm{sc}}$ where $P_{\text {in }}$ is the power of the incident light; $V_{\mathrm{oc}}$ the open-circuit voltage; $J_{\mathrm{sc}}$ the short-circuit current density; FF=fill factor; the voltage and current density at the maximum power point are $V_{\max }$ and $J_{\max }$, respectively. 


\section{Cite this: DOI: $10.1039 / \mathrm{c0xx00000x}$}

electrospun anatase nanofibre mats to improve their adhesion to the substrate ${ }^{206}$. These treatments improved the photocurrent and the conversion efficiency of the corresponding device, which reached a value of $4.14 \%$. A similar result was obtained using $\mathrm{TiO}_{2}$ pre-deposited film by spin-coating ${ }^{207}$. Furthermore, it was shown that the effective electron diffusion coefficient of the NF-based DSC is similar to that of high efficiency nanocrystalline samples. The low electron lifetime and obtained efficiency were explained by the existence of surface traps in the nanofibres.

Another strategy to overcome this problem is to deposit the $\mathrm{TiO}_{2}$ electrospun nanofibres on $\mathrm{TiO}_{2}$ nanoparticles. Such an approach was used by Chuangchote et al. ${ }^{208,209}$ and showed an improvement of the light harvesting properties and of the overall efficiency (up to $10.3 \%$ ) by combining these morphologies (see Fig. 9). Furthermore, the coexistence of NFs or NRs and NPs enhanced the porosity and thus the penetration of the liquid electrolyte and the amount of the adsorbed dye.

The issue of electrolyte penetration into the photoanode material was studied in particular for quasi-solid electrolyte DSCs ( $c f$. $\S 3$. 3.3). Nanorod electrodes were used to fabricate such devices and led to efficient photocurrent generation and an overall conversion of $6.2 \%^{\text {Erreur }}$ : Signet non défini. A hot pressing procedure was successfully used to increase the fibre adhesion to the conductive glass. In another study, electrospun $\mathrm{TiO}_{2}$ NFs were used to epitaxially grow $\mathrm{TiO}_{2}$ rutile crystals. This additional layer modified the photocurrent generation of the prepared DSCs and the energy conversion efficiency increased $30 \%$ after post-treatment, reaching $5 \%^{210}$. In recent studies, the NR morphology seems to show superior performance compared to continuous nanofibres. Rutile 1D NFs and NRs based DSCs were analysed and the higher efficiency of the latter (4.6 vs 1.8\%) was attributed to a strong electronic coupling efficiency of photoexcited electrons. The short size of the rods causes a decrease in the resistance and an increase of the currents ${ }^{211}$.

A further strategy to improve light harvesting and charge collection can be the use of vertical arrays of $\mathrm{TiO}_{2}$ nanowires. The fabrication of such vertically aligned materials by electrospinning followed by a top-down process is very recent (see Table 5$)^{212}$.

$\mathrm{Nb}$ doped anatase nanofibres have been recently explored as photoanode materials for dye-sensitised solar cells ${ }^{213}$. The defects derived from doping play an important role in their photovoltaic properties. The electron diffusion and mobility improved with doping, however the BET surface area decreased and the charge recombination increased.

$\mathrm{ZnO}$ has been investigated as an alternative to $\mathrm{TiO}_{2}$ photoanode material for DSCs, as it possesses similar electron injection process and bandgap as that of $\mathrm{TiO}_{2}$ (3.3 eV vs. $3.2 \mathrm{eV}$ for anatase $)^{214}$. In particular one dimensional $\mathrm{ZnO}$ nanomaterials, which show increased conductivity path, have attracted great attention $^{215}$. In spite of the higher charge transport and electron mobility, 1D $\mathrm{ZnO}$ has poor chemical stability in acidic dye solutions and low surface area compared to titania NP films (and consequently adsorb a minor amount of dye $)^{215}$, resulting in energy conversion efficiencies which are always lower than $\mathrm{TiO}_{2}$ based systems $\left(6.58 \%\right.$ for NP based DSCs ${ }^{216}$ and around $1 \%$ for $1 \mathrm{D} \mathrm{ZnO}$ based $\mathrm{DSCs}^{217}$ ). Many strategies have been applied in order to overcome these drawbacks, and again to improve the fibre adhesion on the substrate and consequently to enhance the overall performance of the systems. The use of electrospun $\mathrm{ZnO}$ fibres in dye-sensitised solar cells was first published in $2007^{217}$. To enhance the electrical contact between the nanofibres and the electrode, hot pressing of the $\mathrm{ZnO} / \mathrm{PVAc}$ precursor NFs was performed before their calcination. This treatment resulted in the formation of dense networks of twisted nanofibres, which further improved the direct conduction paths for efficient electron collection as well as the porosity and surface area. Nevertheless, the efficiency of these systems was low $(1.34 \%)$. A higher energy conversion efficiency of $3.02 \%$ was achieved when a $\mathrm{Zn}(\mathrm{OAc})_{2}$ treatment followed by calcination was performed after the fibre deposition ${ }^{218}$. Electrochemical impedance spectroscopy results showed the effective suppression of the back reaction between photoelectrons (in the $\mathrm{ZnO}$ conduction band) and $\mathrm{I}_{3}{ }^{-}$(in the electrolyte) in the $\mathrm{Zn}(\mathrm{OAc})_{2}$ treated systems, leading to the observed improved performance. In order to further enhance its optical and electrical properties, $\mathrm{ZnO}$ NFs have also been doped with $\mathrm{Al}^{219}$, which enhances their adhesion to fluorine-doped tin oxide (FTO). This was achieved by introducing an $\mathrm{Al}$-doped $\mathrm{ZnO}$ seed layer prepared by electrospinning before the deposition of the Al-doped $\mathrm{ZnO}$ electrospun nanofibres. It was shown that NFs did not crack nor peel away after the calcination step, as this layer facilitated the release of interfacial tensile stress during calcination and improved the interfacial adhesion to the conducting substrate. As a result, the efficiency improved when compared to DSC without seed layers (0.54-0.55\% vs 0.03-0.04\%).

Electrospun nanofibres were also used to form light-scattering layers on photoanode nanomaterials. Such layers could reflect the unabsorbed photons back into the NW anode and improve the DSC efficiency ${ }^{220}$ 


\section{Cite this: DOI: $10.1039 / \mathrm{c0xx00000x}$}

For instance, $\mathrm{Wu}$ et al. deposited $\mathrm{SnO}_{2} / \mathrm{ZnO}$ nanofibres by electrospinning on the surface of $\mathrm{ZnO}$ NWs and formed a film by methanol vapour treatment followed by high-temperature calcination. $J_{\mathrm{sc}}, V_{\mathrm{oc}}$, and FF of the nanofilm/ZnO NW DSCs were all enhanced compared to those of the $\mathrm{ZnO}$ NW DSCs.

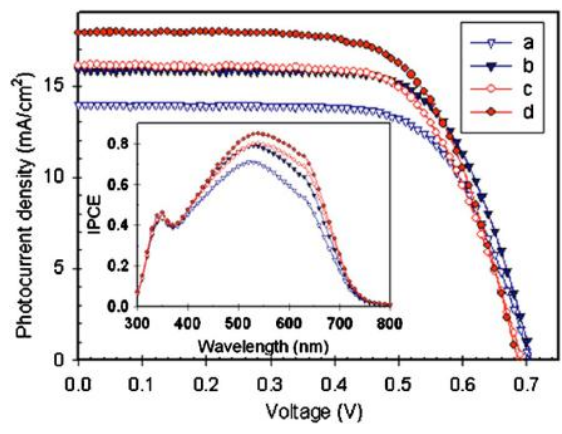

Fig. 9. Photocurrent density-voltage characteristics of NP electrode (a, c) and NP/NF electrode (b, d) at AM1.5 global illumination. Inset: Incident photon-to-current conversion efficiency spectra for those electrodes. The area of electrode was $0.25 \mathrm{~cm}^{2}$. The thicknesses of $\mathrm{TiO}_{2}$ particle layers were $8.4 \mu \mathrm{m}(\mathrm{a}, \mathrm{b})$ and $15.5 \mu \mathrm{m}$ (c, d). Reprinted from ref. 209, Copyright (2008), with permission from American Institute of Physics.

brittleness and high price. Recently, 1D nanostructured networks such as carbon nanotubes and silver nanowires revealed good performances as potential alternatives. However, they present some disadvantages like high junction resistances for CNTs and limited aspect ratios and high price for silver NWs. In this context, electrospinning has been used to prepare copper nanofibre networks by calcination of copper acetate/PVA electrospun fibres that were subsequently reduced in a $\mathrm{H}_{2}$ atmosphere ${ }^{223}$. The power efficiency of organic solar cells using copper nanofibre electrode materials was $3.0 \%$, a value comparable to devices made with standard ITO electrodes. $\mathrm{Cu}$ fibres have ultrahigh aspect ratios (up to 100000), very low junction resistances and great flexibility. Furthermore, their preparation by electrospinning is low-cost and easily scaleable.

Finally, $\mathrm{TiO}_{2}^{224}$ and $\mathrm{ZnO}^{225}$ nanofibrous networks have found very recent use in hybrid solar cells based on poly(3-hexylthiophene) and metal oxides.

\section{3.b.2 Counter electrodes}

The conventional counter electrode in DSCs is platinum, due to its high electrocatalytic activity for $\mathrm{I}_{3}{ }^{-}$ ions reduction ${ }^{193}$. Nevertheless, $\mathrm{Pt}$ is expensive and the corrosive $\mathrm{I}^{-} / \mathrm{I}_{3}{ }^{-}$redox couple can reduce its activity and affect the long-term stability of the overall device ${ }^{226}$. Recent studies deal with the replacement of $\mathrm{Pt}$ in order to decrease the costs and enhance the
We can also cite the use of electrospun materials (e.g. carbon $)^{221}$ as templates for the growth of $\mathrm{ZnO}$ NWs. These composites can be used as an anode material for the fabrication of flexible DSCs.

So far, several studies focused on the active layer on which photosensitive dye is adsorbed have been described here. Another strategy to increase the efficiency of electron transport and improve DSC efficiency is to maximise the interface between the conductive glass electrode and the active layer. Recently, electrospinning of transparent and conductive indium tin oxide (ITO) was performed from a mixture of inorganic precursors and PVP and the resulting nanofibres deposited onto ITO-glass substrates. As an electrode of DSC $^{222}$, improvement leading to $3.97 \%$ efficiency was achieved, due to a reduction in grain boundaries, an efficient high charge collection, and a rapid electron transport.

Electrospun nanofibres can also be used to replace the conductive glass substrate for DSCs which is usually ITO. Indeed, ITO films present several bottlenecks to the real application, including

durability of DSCs. Some of them are still based on Pt,

but in the form of nanoparticles dispersed on conductive materials. For instance, Pt impregnated on mesoporous $\mathrm{Nb}$-doped $\mathrm{TiO}_{2}$ films resulted in large active surface area and high mechanical stability ${ }^{227}$. Other studies have revealed that carbonaceous materials including graphite, carbon black, and CNTs, can exhibit electrocatalytic performance comparable to $\mathrm{Pt}^{226}$ 228. Such materials, in contrast to $\mathrm{Pt}$, are abundant and low-cost, which could facilitate the introduction into the market of dye-sensitised solar cells. For example, electrospun carbon nanofibres have been used recently, as an alternative to platinum for triiodide reduction in DSCs (see Fig. 10) ${ }^{229}$. Such counter electrodes exhibited low charge-transfer resistance, large capacitance, and fast $\mathrm{I}_{3}^{-}$reduction rates. The obtained current density was comparable to those of conventional Pt based cells, although the open circuit potential was lower. The efficiency was also slightly lower because of the lower fill factor, probably due to high total series resistance, $R_{\text {Stot }}$. Thus, although the lower price of such carbon-based conterelectrode makes them an attractive alternative to $\mathrm{Pt}$, the main challenge is in fabricating thinner and highly porous carbon NFs in order to reduce the thickness of the counter electrode and also to decrease $\mathrm{R}_{\text {Stot }}$ to make their performance more competitive. 


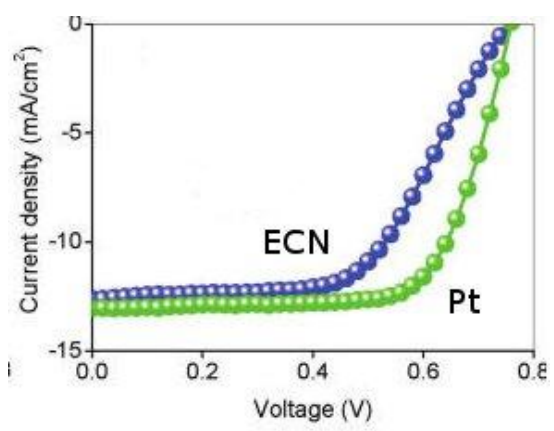

Fig. 10. Current density-voltage $(J-V)$ curves of the DSCs based on electrospun carbon nanofibres (ECN) and $\mathrm{Pt}$ counter electrodes. Reprinted from ref. 229, Copyright (2010), with permission from American Chemical Society.

\section{3.b.3. DSC electrolytes}

The conventional electrolytes for DSCs are liquids (e.g. triiodide/iodide redox couple in organic solvents) leading to overall efficiencies around $11 \%$. The major drawbacks to practical use of such systems is the poor long-term stability due to the volatility of organic solvents, the difficulty in robust sealing, and the leakage of electrolyte in case of breakage. In order to overcome these problems, many studies have been carried out on alternatives to replace the liquid electrolytes. For instance, solid-state electrolytes such as hole conductors ${ }^{230}$ and polymers ${ }^{231}$, that unfortunately show a low solar-to-electricity conversion efficiency because of their low electron injection efficiency. A better alternative is represented by quasi-solid-state DSCs using polymer gel electrolytes $^{232}$ presenting high thermal stability, negligible vapour pressure, good contacting and filling properties with the nanostructured electrodes, and higher ionic conductivity ${ }^{233}$.

So far, several types of polymer gel electrolytes have been used in quasi-solid-state DSCs, such as polyacrylonitrile (PAN) $)^{234}$, poly(ethylene oxide) $(\mathrm{PEO})^{235}$, polymethylmethacrylate (PMMA) $)^{236}$, and poly(vinylidenefluoride-co-hexafluoropropylene) $(\mathrm{PVdF}-\mathrm{HFP})^{237}$.. In particular, the latter shows high ionic conductivity and stability at room temperature.
However, the complex preparation technology and the poor mechanical strength of these gel polymer based DSCs represent a bottleneck to their introduction to the market. To overcome this problem, the electrospinning of such polymers has been performed with the aim of integrating the resulting fibrous, easy to obtain and low-cost materials as electrolytes (see Table 6).

In 2002, Drew et al. reported an "electrospun photovoltaic cell" including electrospun fibres of PAN with an azo-dye (Congo Red) with or without $\mathrm{TiO}_{2}$ nanoparticles. ${ }^{238}$ This system was still based on a liquid junction and showed photocurrents higher than those obtained with a spin-coated film of the same materials. In 2008, Priya et al. prepared an electrospun PVdF-HFP membrane and used it for the first time to form quasi-solid-state DSCs ${ }^{239}$. Its solar-to-electricity conversion efficiency was similar to that obtained for a conventional liquid electrolyte $(7.3 \%$ vs. $7.8 \%)$ while its long-term stability was higher. Indeed, the electrospun membrane electrolyte effectively encapsulated the organic solvent containing the $\mathrm{I}_{3}{ }^{-} / \mathrm{I}^{-}$ redox couple and promoted a strong interfacial contact between the dye-adsorbed $\mathrm{TiO}_{2}$ electrode and the $\mathrm{Pt}$ counter-electrode. Other polymer electrolytes for quasi-solid state DSCs have been fabricated with electrospun PVdF-HFP $240,241,242$, and DSC devices were fabricated using them ${ }^{241}$. The photovoltaic performance of DSC devices using such nanofibre films showed better results compared to DSC devices using the same material films obtained by spin-coating (see also Table 6) ${ }^{240}$. In addition, it was found that the photocurrent density and efficiency of DSC using electrospun PVdF-HFP nanofibres in electrolytes were not proportional to the electrolyte conductivity. A further improvement was achieved very recently by using electrospun PVdF-HFP/polystyrene(PS) blend nanofibres (3:1) which resulted in a $5.3 \%$ conversion efficiency ${ }^{242}$. Lastly, the stability of the electrospun polymer electrolyte-based DSC has been compared to that of the liquid electrolyte-based DSC: after deliberately provoking holes and removing glasses from the cell, the fibrous electrolyte maintained its integrity while the liquid one underwent leakage (see Fig. 11).

Table 6. Electrospun fibres for DSC electrolytes and the resulting photovoltaic parameters obtained under AM 1.5 and $100 \mathrm{~mW} \mathrm{~cm}^{-2}$ of light intensity.

\begin{tabular}{ccccccccc}
\hline Material & $\begin{array}{c}\text { Fibre } \\
\text { diameter } \\
(\mathbf{n m})\end{array}$ & Dye & $\begin{array}{c}\text { Ionic conductivity } \\
\left(\mathbf{m ~ S ~ c m ~}^{-\mathbf{1}}\right)\end{array}$ & $\mathbf{V}_{\mathbf{o c}}(\mathbf{V})$ & $\begin{array}{c}\mathbf{J}_{\mathbf{s c}}(\mathbf{m A} \\
\left.\mathbf{c m}^{-\mathbf{2}}\right)\end{array}$ & $\mathbf{F F}$ & $\boldsymbol{\eta}(\mathbf{\%})$ & $\mathbf{R e f}$ \\
\hline PVdF-HFP & $800-1000$ & $\mathrm{~N} 3$ & 4.53 & 0.75 & 12.3 & 0.57 & 5.21 & 241 \\
$\begin{array}{c}\text { PVdF-HFP/ } \\
(\text { PS })\end{array}$ & $800-1200$ & $\mathrm{~N} 719$ & $1.89 / 2.65$ & $0.71 / 0.76$ & $11.4 / 11.8$ & $0.64 / 0.66$ & $5.37 / 5.75$ & 242 \\
\hline
\end{tabular}




\section{Cite this: DOI: $10.1039 / \mathrm{c} 0 \mathrm{xx} 00000 \mathrm{x}$}
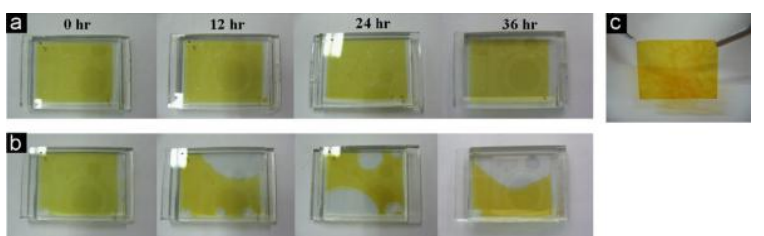

Fig. 11. Stability testing of (a) the electrospun PVdF-HFP nanofibre electrolyte cells, (b) the liquid electrolyte cells, and (c) soaked electrospun PVdF-HFP nanofibre after $36 \mathrm{~h}$. Reprinted from ref. 242, Copyright (2011), with permission from Elsevier.

\section{3.c. Electrospun nanofibres in lithium-ion batteries}

Lithium-ion batteries (LIB) have attracted much research attention and industrial development due to their high energy density, low gravimetric density, long cycle life and flexible design ${ }^{243}$. Indeed, since the 1990s, non-aqueous rechargeable $\mathrm{Li}$-ion batteries have established a strong market position especially for portable electronic devices. In such systems, electrical energy is generated by conversion of chemical energy via redox reactions at the electrodes ${ }^{244}$. In the "rocking-chair" LIB, reactions follow an insertion mechanism: lithium cations are reversibly inserted/extracted into/from a host matrix and this process is accompanied by an electron flow through an external circuit. Upon charging, $\mathrm{Li}^{+}$are released by the cathode and inserted at the anode, while upon discharging, $\mathrm{Li}^{+}$are extracted from the anode and inserted into the cathode. Similarly to fuel cells, the Li-ion cell consists of an anode and cathode separated by an electrolyte, which is an electronic insulator but a $\mathrm{Li}^{+}$conductor. A conventional cell uses a carbon/graphite anode, a lithium-metal oxide $\left(\mathrm{LiCoO}_{2}\right.$, $\mathrm{LiNiO}_{2}, \mathrm{LiMn}_{2} \mathrm{O}_{4}$ ) cathode, and an organic electrolyte of lithium hexafluorophosphate $\left(\mathrm{LiPF}_{6}\right)$ salt with ethylene carbonate (EC)-organic solvent mixture.

So far, LIB have enabled the development of small and portable electronic devices, but future challenges concerning larger and more demanding applications such as electric or hybrid electric vehicles necessitate significant advances in battery technology as they require fast charging and discharging at high power rates. Thus, more improvements are needed in various aspects such as energy density, power, cycling life, charge/discharge rate, safety and $\operatorname{cost}^{2}$ in order for LIBs to achieve satisfactory performance in these demanding applications.

One of the strategies used to improve the efficiency and the durability of LIBs is to maintain a low weight, volume and cost by designing and fabricating nanomaterials and nanostructured materials for use as electrodes and electrolytes ${ }^{245}$, 1 . In this regard, the versatility of electrospinning makes them highly suitable to prepare both these components with the benefits of smaller, nanostructured geometries and architectures and reduced manufacturing costs. In this next section, recent advances in the areas of electrospun cathodes, anodes, and separator membranes for LIBs are described and summarised (see also Tables 7-9).

\section{3.c.1 Electrode materials}

In order to achieve high specific energy and energy density, electrode materials for rechargeable Li-ion batteries must possess a high specific charge and charge density, generate a high cell voltage, and have a high reversibility of electrochemical reactions at both electrodes to maintain the specific charge for thousands of charge-discharge cycles. Nanostructured materials have been extensively explored to prepare high-performance LIB electrodes, due to the multiple advantages that they possess ${ }^{246},{ }^{247}$. Firstly, the nanometre size significantly increases the rate of $\mathrm{Li}^{+}$ insertion/extraction because of the short diffusion length for lithium-ion transport within the particles, enhancing the rate capability and power density. The same is also true for electron transport, which is also enhanced in nanomaterials. Secondly, their high surface area allows a high electrode/electrolyte contact area that can increase the rate capability of the device. Finally, the range of composition of solid solutions is often more extensive for nanoparticles, and the strain associated with insertion/extraction is often better accommodated, avoiding destruction of the material structure (electrochemical grinding) and improving the cycle life of the cell.

Despite these advantages, the use of nanomaterials in LIB also introduces new challenges. The large surface area can enhance the reaction between electrodes and electrolyte, leading to an increase in solid-electrolyte interfacial (SEI) layer area, self discharge, and decrease in cycle life. Furthermore, the low packing density of nanostructured materials can result in lower volumetric energy density compared to micrometric and bulk materials. There may also be issues regarding the complexity of the synthetic methods and the difficulty of accurately controlling the size of nanomaterials, which may result in greater processing and manufacturing costs. Taking these challenges into account, among the wide range of morphologies nanowires show great potential in this 


\title{
Cite this: DOI: $10.1039 / \mathrm{c0xx00000x}$
}

\author{
www.rsc.org/xXXXXX
}

ARTICLE TYPE

area because of their better percolation behaviour than particles ${ }^{1,}{ }^{248}$. Soft-chemistry routes and template syntheses are usually employed to synthesize nanostructured electrodes, and after sintering treatment they often result in large grain size and aggregation, losing the high surface areas and its associated merits ${ }^{249}$. In this regard, electrospinning presents a simple and versatile alternative approach for preparing nanostructured anode and cathode hosts

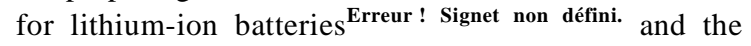
main results in this area will be discussed here.

\section{Cathode materials}

Recent years have witnessed a growing development of the electrospinning of transition-metal oxide with different phases (layered, anatase, spinel, etc...) as cathodes for lithium-ion batteries. By modifying the electrospinning configuration and the post-treatments, a wide variety of morphologies and architectures were studied such as nanowires ${ }^{250}$, nanobelts ${ }^{251}$, nanonuggets ${ }^{252}$, biaxial $^{253}$ and triaxial ${ }^{254}$ core-sheath, and hollow ${ }^{255}$ fibres.

Among the materials available, most commercial batteries use $\mathrm{LiCoO}_{2}$ in the cathode due to its good performance in terms of specific energy density (theoretical capacity $140 \mathrm{~mA} \mathrm{~h} \mathrm{~g}^{-1}$ ) and cycle life $\mathrm{e}^{256}$. Nanostructured $\mathrm{LiCoO}_{2}$ fibre electrodes have been prepared by electrospinning with the aim of achieving a fast solid state diffusion due to the short diffusion distance of $\mathrm{Li}^{+}$cations ${ }^{257,258}$. Gu et al. ${ }^{258}$ prepared
$\mathrm{LiCoO}_{2}$ fibre electrodes with large surface area and small pores, with a high initial discharge capacity of $182 \mathrm{~mA} \mathrm{~h} \mathrm{~g}^{-1}$ compared with ca. $140 \mathrm{~mA} \mathrm{~h} \mathrm{~g}^{-1}$ for conventional powder and film electrodes. However, such nanostructured cathodes suffered from a large loss of capacity during the charge-discharge process resulting from the dissolution of cobalt and lithium cations forming $\mathrm{Li}_{2} \mathrm{CO}_{3}$ and $\mathrm{CoF}_{2}$ impurities. $\mathrm{A}$ promising strategy to increase stability and cycling performance is by coating of the nanofibres. For instance, using coaxial electrospinning, $\mathrm{LiCoO}_{2}$ fibres ${ }^{253}$ and $\mathrm{LiNi}_{0.8} \mathrm{Co}_{0.1} \mathrm{Mn}_{0.1} \mathrm{O}_{2}$ tubes ${ }^{255}$ covered with a $\mathrm{MgO}$ shell were prepared. The $\mathrm{MgO}$ coating avoided impedance growth by protecting the surface from passive film formation during cycling. The core-sheath fibre electrode showed improved reversibility and cyclability. After 40 cycles, $90 \%$ of the initial discharge capacity of $\mathrm{LiCoO}_{2} / \mathrm{MgO}$ was maintained, compared to $52 \%$ for the uncoated fibre electrode. The hollow fibres showed still better performances in terms of capacity and cycling stability (see Fig. 12 and Table 7). Similarly, electrospun core-shell $\mathrm{Li}\left(\mathrm{Ni}_{1 / 3} \mathrm{Co}_{1 / 3} \mathrm{Mn}_{1 / 3}\right) \mathrm{O}_{2} / \mathrm{Li}\left(\mathrm{Ni}_{1 / 2} \mathrm{Mn}_{1 / 2}\right) \mathrm{O}_{2} \quad$ fibres exhibited an enhanced cycle stability compared to core $\mathrm{Li}\left(\mathrm{Ni}_{1 / 3} \mathrm{Co}_{1 / 3} \mathrm{Mn}_{1 / 3}\right) \mathrm{O}_{2}$ fibres with the loss of $24.5 \%$ of the initial capacity after 40 cycles $^{259}$. A lithium phosphorous oxynitride (LiPON) layer deposited by radio-frequency sputtering was also effective in stabilising $\mathrm{LiCoO}_{2}$ fibre performance, with a loss of $0.11 \%$ per cycle after 100 cycles at the discharge rate of $0.05 \mathrm{~mA} \mathrm{~cm}^{-2} 260$.
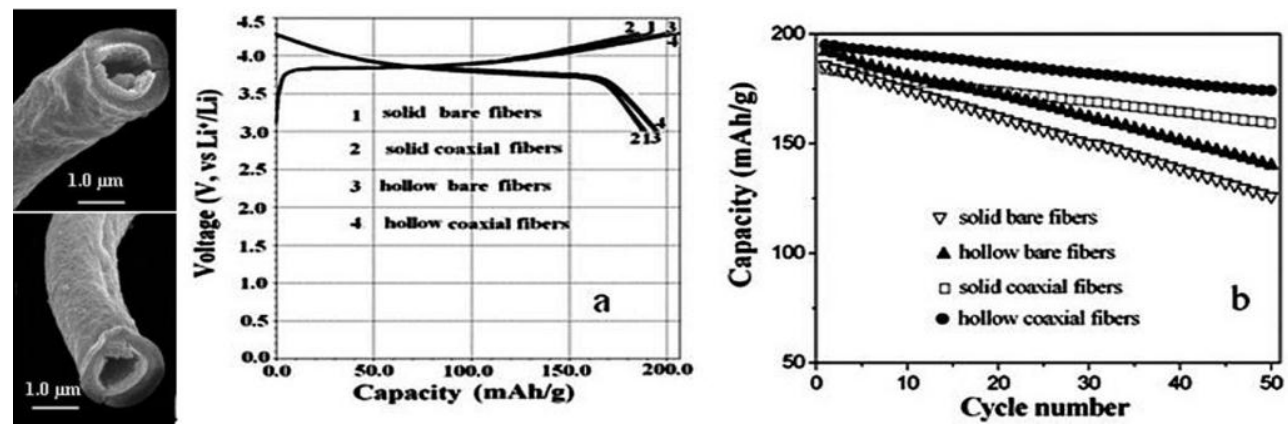

Fig. 12. SEM micrographs of hollow coaxial fibres obtained at (a) 0.4 and (b) 0.5 molar ratios of $\mathrm{PVP} /\left(\mathrm{Ni}^{2+}+\mathrm{Co}^{2+}+\mathrm{Mn}^{2+}\right)$. The initial charge-discharge curves (c) and capacity retention versus cycle number plots (d) of the fibre electrodes at a current density of $20 \mathrm{~mA} \mathrm{~g}^{-1}$. Reprinted from ref.255, Copyright (2008), with permission from American Chemical Society.

Table 7. Electrospun cathodes and the corresponding electrochemical performance.

\begin{tabular}{|c|c|c|c|c|c|c|}
\hline Material & $\begin{array}{l}\text { Fibre diameter } \\
(\mathbf{n m}) / \text { structure }\end{array}$ & $\begin{array}{l}\text { Crystallite } \\
\text { size }(\mathbf{n m})\end{array}$ & $\begin{array}{c}\text { BET } \\
\text { surface } \\
\left(\mathrm{m}^{2} \mathrm{~g}^{-1}\right)\end{array}$ & $\begin{array}{c}\text { Discharge } \\
\text { capacity } 1^{\text {st }} \\
\text { cycle }\left(\mathbf{m A h} \mathbf{g}^{-1}\right) \\
{[\operatorname{rate}(\mathbf{C})]} \\
\end{array}$ & $\begin{array}{c}\text { Discharge } \\
\text { capacity } \mathbf{n}^{\text {th }} \\
\text { cycle }\left(\mathbf{m A h} \mathbf{g}^{-1}\right) \\
{[\operatorname{rate}(\mathbf{C})]} \\
\end{array}$ & Ref. \\
\hline $\mathrm{LiCoO}_{2}$ & $500-2000$ & $20-35$ & 18 & $182[0.14]$ & $\begin{array}{c}\mathrm{n}=2,173, \mathrm{n}=20 \\
123[0.14]\end{array}$ & 258 \\
\hline
\end{tabular}


Cite this: DOI: $10.1039 / \mathrm{c0xx} 00000 \mathrm{x}$

www.rsc.org/xxxxxx

ARTICLE TYPE

\begin{tabular}{|c|c|c|c|c|c|c|}
\hline $\mathrm{LiCoO}_{2} / \mathrm{MgO}$ & $\begin{array}{c}1000-2000 \\
\text { shell } 10-100\end{array}$ & $<10$ & 20 & $181[0.14]$ & $\begin{array}{c}\mathrm{n}=40,163 \\
{[0.14]}\end{array}$ & 253 \\
\hline LiPON coated $\mathrm{LiCoO}_{2}$ & $\begin{array}{c}60-80 / \\
3 \mathrm{D} \text { architecture }\end{array}$ & $\mathrm{NA}^{*}$ & NA & 129 [NA] & $\begin{array}{c}\mathrm{n}=2,128 \\
\mathrm{n}=100,120 \\
{[\mathrm{NA}]}\end{array}$ & 260 \\
\hline $\mathrm{LiNi}_{0.8} \mathrm{Co}_{0.1} \mathrm{Mn}_{0.1} \mathrm{O}_{2} / \mathrm{MgO}$ & $\begin{array}{c}1000-2000 \\
\text { 30-60 shell } 300- \\
500 \text { wall/ } \\
\text { hollow coaxial }\end{array}$ & NA & 30 & $195[0.14]$ & $\begin{array}{c}\mathrm{n}=50,174 \\
\quad[0.14]\end{array}$ & 255 \\
\hline $\begin{array}{l}\mathrm{Li}\left(\mathrm{Ni}_{1 / 3} \mathrm{Co}_{1 / 3} \mathrm{Mn}_{1 / 3}\right) \mathrm{O}_{2} / \\
\mathrm{Li}\left(\mathrm{Ni}_{1 / 2} \mathrm{Mn}_{1 / 2}\right) \mathrm{O}_{2}\end{array}$ & $\begin{array}{c}<5000 \\
\text { shell } 300\end{array}$ & $20-50$ & NA & $192[0.1]$ & $\begin{array}{c}\mathrm{n}=2,171, \\
\mathrm{n}=5,166[0.1]\end{array}$ & 259 \\
\hline $\mathrm{Ta}-\mathrm{Nb}_{2} \mathrm{O}_{5}$ & $\begin{array}{c}\approx 100-200 \\
\text { NFs/nanonuggets }\end{array}$ & NA & $3-6$ & $\begin{array}{l}\approx 500-800[1], \\
\approx 240-150[1.5]\end{array}$ & $\begin{array}{c}\mathrm{n}=40, \approx 350-150 \\
\quad[1] ; \mathrm{n}=50, \\
\approx 170-100[1.5]\end{array}$ & 252 \\
\hline $\mathrm{LiFePO}_{4} / \mathrm{C}$ & $100-300$ & $18-28$ & NA & $\begin{array}{c}166[0.05], \\
140[0.1], \\
125[0.2], \\
98[0.5], \\
71[1], 37[2]\end{array}$ & $\begin{array}{c}\mathrm{n}=50, \approx 140 \\
{[0.1], \approx 120} \\
{[0.2]}\end{array}$ & 263 \\
\hline $\mathrm{C} / \mathrm{LiFePO}_{4} / \mathrm{C}$ & $\begin{aligned} \approx 400-1000 / \\
\\
\text { triaxial }\end{aligned}$ & NA & NA & $\begin{array}{c}160[0.06], \\
130[0.6], \\
80[6]\end{array}$ & $\begin{array}{c}\mathrm{n}=20, \approx 160 \\
\quad[0.06], \\
\approx 130[0.6], \\
\\
\approx 80[6]\end{array}$ & 254 \\
\hline $\mathrm{LiFePO}_{4} / \mathrm{C}$ & $\begin{array}{c}100 / \\
\text { shell 2-5 }\end{array}$ & NA & NA & $\begin{array}{c}169[0.1], \\
162[0.5], \\
150[1], 114 \\
{[5], 93[10]}\end{array}$ & $\mathrm{n}=100,146[1]$ & 264 \\
\hline $\mathrm{V}_{2} \mathrm{O}_{5}$ & $\begin{array}{c}40-70 \times 10-20 / \\
\text { nanobelts }\end{array}$ & NA & NA & $350[\mathrm{NA}]$ & $\mathrm{n}=25,270[\mathrm{NA}]$ & 251 \\
\hline $\mathrm{V}_{2} \mathrm{O}_{5}\left(+\mathrm{V}_{\mathrm{x}} \mathrm{O}_{2}\right)$ & $100-200$ & $\begin{array}{l}50 \times 100 \\
\text { NRs }\end{array}$ & NA & $275-390[\mathrm{NA}]$ & $\begin{array}{c}\mathrm{n}=50,187-201 \\
{[\mathrm{NA}]}\end{array}$ & 250 \\
\hline $\mathrm{V}_{2} \mathrm{O}_{5}$ & $300-800$ & $70-80$ & NA & $\begin{array}{l}300[0.1], \\
160[1.0]\end{array}$ & $\begin{array}{c}\mathrm{n}=20,200[0.1] \\
112[1.0] ; \\
\mathrm{n}=50,150[0.1]\end{array}$ & 265 \\
\hline $\mathrm{V}_{2} \mathrm{O}_{5}$ & 350 & $\approx 100$ & 97 & 377 [NA] & $\begin{array}{c}\mathrm{n}=10,347 \\
\mathrm{n}=40,344[\mathrm{NA}]\end{array}$ & 266 \\
\hline
\end{tabular}

Furthermore, the particular 3D structure electrode of the latter material, presenting highly accessible surface areas and continuous networks seems very promising for the design of novel batteries that maximise power and energy density.

$\mathrm{LiFePO}_{4}$ is a highly promising candidate for positive electrode material because of its large specific capacity (170 mA h g $\left.{ }^{-1}\right)$, high discharge potential, good thermal stability, low toxicity, low cost and safety. However, it suffers from low ionic and electronic conductivity, leading to low rate capability and high impedance in LIBs. One of the most investigated strategies to avoid this limitation is coating this material with carbon in order to introduce an electron path ${ }^{261}$. Furthermore, such a coating protects the surface from undesired side reactions leading to $\mathrm{Fe}^{3+}$ and $\mathrm{Li}_{3} \mathrm{PO}_{4}{ }^{262}$. Several studies are devoted to composite $\mathrm{LiFePO}_{4} /$ carbon nanofibres obtained by electrospinning $254,263,264$.
Very recently, Zhu et al. reported on singlecrystalline thin $(100 \mathrm{~nm})$ carbon-coated $\mathrm{LiFePO}_{4}$ nanowires ${ }^{264}$. The carbon coating and the threedimensional connectivity of the network ensured high conductivity that, together with the liquid electrolyte, led to fast $\mathrm{Li}^{+}$transport. Very good rate performance and cycling capability were obtained. For instance at $0.1 \mathrm{C}$ discharge rate, the capacity was close to theoretical $\left(169 \mathrm{~mA} \mathrm{~h} \mathrm{~g}^{-1}\right)$ and after 100 cycles at $1 \mathrm{C}$ it was $86 \%$ of the theoretical value $\left(146 \mathrm{~mA} \mathrm{~h} \mathrm{~g}^{-1}\right)$. Furthermore, after cycling, the morphology of the carbon-coated $\mathrm{LiFePO}_{4}$ fibres was maintained.

Vanadium pentoxide has high theoretical capacity (ca. $400 \mathrm{~mA} \mathrm{~h} \mathrm{~g}^{-1}$ ), but the performance of conventional bulk $\mathrm{V}_{2} \mathrm{O}_{5}$ powder cathodes is limited by low electronic conductivity, slow lithium diffusion rate and structural instability upon charge/discharge cycling. To overcome these problems, the use of electrospinning to prepare nanostructured $\mathrm{V}_{2} \mathrm{O}_{5}$ 


\section{Cite this: DOI: $10.1039 / \mathrm{c0xx00000x}$}

positive electrodes is growing ${ }^{250,251,265}$. For instance, Cheah et al. have prepared single phase electrospun $\mathrm{V}_{2} \mathrm{O}_{5}$ fibres that present an initial discharge capacity of $320 \mathrm{~mA} \mathrm{~h} \mathrm{~g}^{-1}$ and excellent coulombic efficiency $(\approx 100 \%)$ throughout 50 charge-discharge cycles $^{265}$. This study highlights once again the importance of the network morphology of electrospun fibres to increase the electroactive surface area, thus improving the accessibility of electrolyte to the cathode material and the overall efficiency of the Li-ion batteries. The use of mesoporous nanofibres further improves the performance especially in term of cycling stability ${ }^{266}$.

\section{Anode materials}

Cycle life and rate capability of lithium ion batteries strongly depend on the properties of the anode material, while their electrical storage capacities depends on how much lithium can be held in said anode. Most current batteries use carbon as its anode, replacing metallic lithium found in early batteries. Carbon provides several advantages such as safety, low cost and greater cell life, however it also has lower cell voltage, specific charge (theoretical capacity of $372 \mathrm{~mA} \mathrm{~h} \mathrm{~g}^{-1}$ ), and rate capability. In order to improve these properties, researchers have investigated control of the anode nanostructures in order to increase its performance with regards to the above parameters.

Carbon nanofibre (CNF) anodes have been prepared through a combination of polymer electrospinning and thermal treatments. PAN derived fibres treated at 1000 ${ }^{\circ} \mathrm{C}$ exhibited the highest reversible capacity for pure carbon (ca. $450 \mathrm{~mA} \mathrm{~h} \mathrm{~g}^{-1}$ ), and a good rate capability $\left(350 \mathrm{~mA} \mathrm{~h} \mathrm{~g}^{-1}\right.$ ) (at a charge current of $100 \mathrm{~mA} \mathrm{~h} \mathrm{~g}^{-1}$ ) due to their particular microtexture, comprising a highly disordered structure, defects, and dangling bonds $^{267}$. CNFs prepared from a bicomponent polymer mixture (PAN/polypyrrole) also showed a relatively large reversible capacity (ca. $360 \mathrm{~mA} \mathrm{~h} \mathrm{~g}^{-1}$ ), high rate capability, good cycle performance and structural integrity after 50 charge/discharge cycles, attributable to their large surface area and extended interface with electrolyte, leading to short pathway for charge and electron transport ${ }^{268}$.

Studies on anode materials also concern electrospun carbon fibres loaded with metal or oxide nanoparticles. For instance, CNF have been doped with silicon ${ }^{269,} 270$ and $\operatorname{tin}^{271,272,273,274}$ NPs. Indeed, Si and $\mathrm{Sn}$ have high theoretical capacity $\left(4200 \mathrm{~mA} \mathrm{~h} \mathrm{~g}^{-1}\right.$ and $992 \mathrm{~mA} \mathrm{~h} \mathrm{~g}^{-1}$, respectively), but suffer from poor cycling performance owing to large volume changes by up to $400 \%$ for $\mathrm{Si}$ and nanoparticle aggregation upon the alloying and dealloying reaction with $\mathrm{Li}^{+}$ ions ${ }^{275}$. One of the strategies proposed to overcome these drawbacks is by dispersing nano-sized particles within carbon nanofibres that act as structural buffers, particle stabilisers, and electroactive materials, and eliminate the need for binding or conducting additives. The effect of the surrounding confinements of nanoparticles is fundamental, and was studied in the case of $\mathrm{Si}$ by Choi et al. ${ }^{270}$. Hard confinements contributed to suppressing the volume expansion of $\mathrm{Si}$ NPs during charge/discharge cycles. The improvements on reversible capacity and cycle stability were mainly attributable to the formation of nanofibrillar networks favouring electronic and ionic transport through the surrounding confinements as in the case of Si@CNF. It was shown that an important role is also played by the electrical conduction of the surrounding material. Carbonisation temperature is also a key factor for electrospun NPs/C anode materials since affecting their morphology and electrochemical performance. $\mathrm{Yu}$ et al. prepared tin nanoparticle-dispersed carbon $(\mathrm{Sn} / \mathrm{C})$ nanofibres by stabilisation of electrospun $\mathrm{SnCl}_{4} / \mathrm{PAN}$ fibres and subsequent carbonisation at different temperatures ${ }^{274}$. $\mathrm{Sn} / \mathrm{C}$ nanofibres at 700 and $850{ }^{\circ} \mathrm{C}$ presented the highest charge (785.8 and $811 \mathrm{~mA} \mathrm{~h} \mathrm{~g}^{-1}$ ) and discharge (1211.7 and $993 \mathrm{~mA} \mathrm{~h} \mathrm{~g}^{-1}$ ) capacities due to the unique feature of reticular nanofibre geometries.

Fibrous carbon anodes have also been loaded with transition-metal oxide nanoparticles such as $\mathrm{Co}_{3} \mathrm{O}_{4}{ }^{276}$, $\mathrm{Fe}_{3} \mathrm{O}_{4}{ }^{277}$ and $\mathrm{MnO}_{\mathrm{x}}{ }^{278}$. Such materials have been widely investigated as anode materials in LIBs, because of their high theoretical capacities, safety, non-toxicity and low $\operatorname{cost}^{279}$. However, they have a poor electronic conductivity and a large volume change during repeated lithium insertion/de-insertion. The formation of composite nanofibres by insertion of nanometric metal oxides in electrospun CNFs is again a promising solution. One example is provided by the preparation of $\mathrm{MnO}_{\mathrm{x}} / \mathrm{CNFs}$ by electrospinning combined with electrodeposition; high reversible capacity $\left(618 \mathrm{~mA} \mathrm{~h} \mathrm{~g}^{-1}\right)$, good capacity retention, and great morphological integrity were shown after cycling (see Fig. 13).

The exceptional improvement of anode performance (see Table 8) upon the incorporation of a Li-inactive metal such as $\mathrm{Ni}$ in $\mathrm{CNF}^{280}$ is particularly noteworthy. 


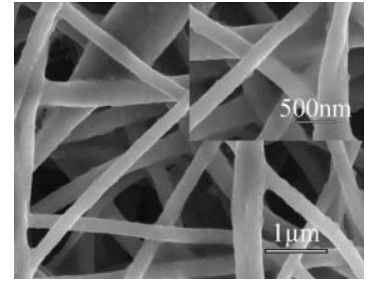

Fig. 13. SEM images of $\mathrm{MnO}_{\mathrm{x}} / \mathrm{CNFs}$ after 100 charge/discharge cycles at a constant current density of $50 \mathrm{~mA} \mathrm{~g}^{-1}$. Deposition time: $10 \mathrm{~h}$. The inset shows $\mathrm{MnO}_{\mathrm{x}} / \mathrm{CNFs}$ with higher magnification. Reprinted from ref. 278, Copyright (2010), with permission from Elsevier.

The last typology of electrospun anode materials for LIBs is represented by pure metal oxide fibres ${ }^{281,282,}$ 283, 284, 285, 286, 287. Among them, $\mathrm{SnO}_{2}$ and $\mathrm{TiO}_{2}$ have been intensively investigated ${ }^{288}$. Due to their particular porous structure, electrospun $\mathrm{SnO}_{2}$ fibres consisting of nanoparticles were shown to facilitate electrolyte diffusion, charge transfer and the mechanical strain due to the volume changes during charge/discharge Erreur ! Signet non défini. The electrochemical performance was improved, reaching high specific capacity (446 $\mathrm{mA} \mathrm{h} \mathrm{g}$ after 50 cycles at a $100 \mathrm{~mA} \mathrm{~g}^{-1}$ rate), and high rate capability $\left(477.7 \mathrm{~mA} \mathrm{~h} \mathrm{~g}{ }^{-1}\right.$ at $\left.10 \mathrm{C}\right)$. However, it was considered that the large irreversible capacity and capacity fading that were observed probably derived from side reactions of the large surface area with the electrolyte. The performance was further improved by exploiting the versatility of electrospinning and preparing $\mathrm{SnO}_{2}$ porous nanotubes, that delivered a high discharge

Table 8. Electrospun anodes and the corresponding electrochemical performance.

\begin{tabular}{|c|c|c|c|c|c|c|}
\hline Material & $\begin{array}{c}\text { Fibre/NP } \\
\text { diameter } \\
(\mathbf{n m}) / \text { structure }\end{array}$ & $\begin{array}{l}\text { Crystallite/pore } \\
\text { size (nm) }\end{array}$ & $\begin{array}{c}\text { BET } \\
\text { surface } \\
\left(\mathrm{m}^{2} \mathrm{~g}^{-1}\right)\end{array}$ & $\begin{array}{c}\text { Discharge } \\
\text { capacity } 1^{\text {st }} \\
\text { cycle }\left(\mathbf{m A h} \mathbf{~ g}^{-1}\right) \\
{[\operatorname{rate}(\mathrm{C})]}\end{array}$ & $\begin{array}{c}\text { Discharge } \\
\text { capacity } \mathbf{n}^{\text {th }} \text { cycle } \\
\left(\mathbf{m A h} \mathbf{g}^{-1}\right) \text { [rate } \\
(\mathbf{C})]\end{array}$ & Ref. \\
\hline C NFs & $200-300$ & $0.5-5$ & NA & $1000[0.08]$ & $\begin{array}{c}\mathrm{n}=2,500[0.08] \\
\mathrm{n}=20,479, \mathrm{n}=50\end{array}$ & 267 \\
\hline C NFs & $\approx 150-300$ & NA & NA & $621[0.13]$ & $\begin{array}{c}454[0.13] \\
\mathrm{n}=2,440[0.27] \\
\mathrm{n}=2,345[0.54]\end{array}$ & 268 \\
\hline $\begin{array}{c}\mathrm{C} N \mathrm{NFs}+\mathrm{Si} \\
\mathrm{NPs}\end{array}$ & NA & NA & NA & $\begin{array}{l}1710[0.1] \\
870[0.33]\end{array}$ & $\begin{array}{c}\mathrm{n}=5,1150, \mathrm{n}=50 \\
1100[0.1] ; \\
\mathrm{n}=30, \approx 700[0.33]\end{array}$ & 269 \\
\hline $\begin{array}{c}\mathrm{C} N F s+\mathrm{Si} \\
\mathrm{NPs}\end{array}$ & $\begin{array}{l}300-500 \\
50-80 \mathrm{Si}\end{array}$ & NA & NA & $1060-780[0.01]$ & $\begin{array}{c}\mathrm{n}=50,410-380 \\
{[0.01]}\end{array}$ & 270 \\
\hline $\begin{array}{l}\text { C NFs + } \\
\text { Sn NPs }\end{array}$ & $\begin{array}{l}100-1000 \\
\mathrm{Sn} \approx 1\end{array}$ & NA & NA & 816 [NA] & $\mathrm{n}=20,400[\mathrm{NA}]$ & 271 \\
\hline $\begin{array}{l}\mathrm{C} \mathrm{NFs}+ \\
\mathrm{Sn} / \mathrm{SnO}_{\mathrm{x}} \\
\mathrm{NPs}\end{array}$ & $\begin{array}{l}\approx 50-500 \\
\text { Sn } 20-40\end{array}$ & NA & 352 & $1192[0.03]$ & $\mathrm{n}=40, \approx 520[0.03]$ & 272 \\
\hline $\begin{array}{l}\text { C NFs + } \\
\text { Sn NPs }\end{array}$ & $\begin{array}{c}150-350 \\
\text { Sn } 30-40 \\
150\end{array}$ & NA & NA & $1211.7[0.025]$ & $\begin{array}{c}\mathrm{n}=2, \approx 800 \\
{[0.025]} \\
\mathrm{n}=100, \approx 780\end{array}$ & 274 \\
\hline $\begin{array}{c}\mathrm{C} \mathrm{NFs}+ \\
\text { Sn@C NPs }\end{array}$ & $\begin{array}{c}\text { hollow fibres } \\
\text { wall thickness } 30 \\
\text { Sn 100@10 }\end{array}$ & NA & NA & $1156[0.1]$ & $\begin{array}{c}{[0.1] ; \mathrm{n}=100,} \\
\quad \approx 450 \\
{[5]}\end{array}$ & 272 \\
\hline $\begin{array}{l}\text { C NFs + } \\
\text { Ni NPs }\end{array}$ & $\begin{aligned} \approx & 150-200 \\
& \text { Ni } 20\end{aligned}$ & NA & NA & $\begin{array}{l}795[0.13], \\
\approx 570[0.8], \\
\approx 450[1.34], \\
\approx 400[2.7]\end{array}$ & $\begin{array}{c}\mathrm{n}=50, \approx 500[0.13], \\
\approx 400[0.8], \approx 350 \\
{[1.34], \approx 250[2.7]}\end{array}$ & 280 \\
\hline $\begin{array}{c}\mathrm{C} \mathrm{NFs}+ \\
\mathrm{MnO}_{\mathrm{x}} \text { NPs }\end{array}$ & $\begin{array}{c}\approx 150-200 \\
\mathrm{MnO}_{\mathrm{x}} 21-42\end{array}$ & NA & NA & $\approx 650[\mathrm{NA}]$ & $\begin{aligned} \mathrm{n} & =2,558, \mathrm{n}=50 \\
& \approx 500[\mathrm{NA}]\end{aligned}$ & 278 \\
\hline $\begin{array}{c}\mathrm{CNFs}+ \\
\mathrm{Fe}_{3} \mathrm{O}_{4} \mathrm{NPs}\end{array}$ & $\begin{array}{c}\approx 350 \\
\mathrm{Fe}_{3} \mathrm{O}_{4} 8-52\end{array}$ & NA & NA & $\begin{array}{c}1551[0.22] \\
623[1.73]\end{array}$ & $\begin{array}{c}\mathrm{n}=7,763 \\
\mathrm{n}=80,1007[0.22]\end{array}$ & 277 \\
\hline $\mathrm{SnO}_{2}$ & $\approx 50-80$ & 10 & NA & $1650[0.1]$ & $\mathrm{n}=50, \approx 480[0.13]$ & $\begin{array}{l}\text { Erreur ! } \\
\text { Signet non } \\
\text { défini. }\end{array}$ \\
\hline $\mathrm{SnO}_{2}$ & $\begin{array}{c}220 \\
\text { nanotubes }\end{array}$ & pores 11 & 28 & $1650[0.23]$ & $\begin{array}{l}\mathrm{n}=2, \approx 1100 \mathrm{n}=50, \\
807[0.23] ; \mathrm{n}=40,\end{array}$ & $\begin{array}{c}\text { Erreur ! } \\
\text { Signet non }\end{array}$ \\
\hline
\end{tabular}




\section{Cite this: DOI: $10.1039 / \mathrm{c} 0 \mathrm{xx} 00000 \mathrm{x}$}

wall thickness 25

$\begin{array}{cc}\mathrm{TiO}_{2} & 60 \\ \mathrm{Li}_{4} \mathrm{Ti}_{5} \mathrm{O}_{12} & 100-200 / \\ & \text { 3D cross-bar NFs } \\ \mathrm{Co}_{3} \mathrm{O}_{4} & 200 \\ \mathrm{Co}_{3} \mathrm{O}_{4} / \mathrm{C} & 200-300 \\ \mathrm{Mn}_{3} \mathrm{O}_{4} & 100-300 \\ & 50 \\ \mathrm{Ag} \mathrm{or} \mathrm{Au} / & \mathrm{NP} \mathrm{5-10} \\ \mathrm{TiO}_{2} & <1000 \\ \mathrm{Li}_{4} \mathrm{Ti}_{5} \mathrm{O}_{12} & \\ +\operatorname{graphene} & \end{array}$

capacity of $807 \mathrm{~mA} \mathrm{~h} \mathrm{~g}^{-1}$ after 50 cycles and retained a high fraction of their theoretical capacity even after

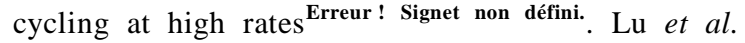
prepared 3D architectures stacked from a cross-bar array of aligned electrospun fibres ${ }^{289}$. They compared cathodic performances of 3D networks of anatase $\mathrm{TiO}_{2}$ and spinel $\mathrm{Li}_{4} \mathrm{Ti}_{5} \mathrm{O}_{2}$ and they found that the first was destroyed after $\mathrm{Li}^{+}$insertion, while the latter showed a

stable architecture and a good reversibility in electrochemical cycles.

Recently LIB anodes based on titania nanofibres loaded with $10 \% \mathrm{Au}$ or $\mathrm{Ag}$ nanoparticles showed improved performance compared to the bare material. The inserted metallic NPs not only decreased the charge transfer, but also enhanced the electronic conductivity of the composite $\mathrm{TiO}_{2}$. The capacity was improved by $20 \%$ or more compared to bare $1 \mathrm{D} \mathrm{TiO}_{2}$ especially for the material doped with gold.

Finally, another promising example of metal oxide anode material obtained by electrospinning is tricobalt tetraoxide, known for its high reversible capacity and electrochemical stability. $\mathrm{Co}_{3} \mathrm{O}_{4} \quad$ electrospun nanofibres delivered an initial discharge capacity of $1336 \mathrm{~mA} \mathrm{~h} \mathrm{~g}^{-1}$ that, after 40 cycles, was maintained at $604 \mathrm{~mA} \mathrm{~h} \mathrm{~g}^{-1}$. This result can be ascribed to the high surface area developed by the NFs ${ }^{\text {Erreur } ! \text { Signet non défini. }}$.

\section{3.c.2 Li-ion battery separators}

Polymer electrolytes have received significant attention in lithium-ion battery applications since they have the advantages of being safer than liquid electrolytes. In general, the polymer electrolyte uses a polymer gel consisting of an electrolyte solution encapsulated in a polymer such as poly(vinylidene fluoride-co-hexafluoropropylene) (PVdF-co-HFP). Despite their advantages, polymer gel membranes also

\begin{tabular}{|c|c|}
\hline $\begin{array}{l}\approx 350[2.4] ; \mathrm{n}=30, \\
\quad \approx 150[10]\end{array}$ & défini. \\
\hline $\mathrm{n}=50, \approx 90[0.45]$ & 248 \\
\hline $\begin{array}{c}\mathrm{n}=30,140[0.5], \\
87[1.5]\end{array}$ & 289 \\
\hline $\mathrm{n}=40,604[0.5]$ & $\begin{array}{l}\text { Erreur ! } \\
\text { Signet non } \\
\text { défini. }\end{array}$ \\
\hline $\mathrm{n}=20,861[0.11]$ & 276 \\
\hline $\begin{array}{c}\mathrm{n}=5, \approx 650 \\
\mathrm{n}=50, \approx 450[\mathrm{NA}]\end{array}$ & $\begin{array}{c}\text { Erreur ! } \\
\text { Signet non } \\
\text { défini. } \\
\text { Erreur ! }\end{array}$ \\
\hline $\mathrm{n}=2,160-170[1]$ & $\begin{array}{l}\text { Signet non } \\
\text { défini. } \\
\text { Erreur! }\end{array}$ \\
\hline $\mathrm{n}=1200,100[22]$ & $\begin{array}{l}\text { Signet non } \\
\text { défini. }\end{array}$ \\
\hline
\end{tabular}

have drawbacks due to poor mechanical properties and sometimes unsatisfactory thermal stability. In some cases, this can be improved by, for example, using highly crystalline PVdF homopolymer, however the crystallinity of the polymer hinders the migration of lithium ions, and as such is detrimental to the ionic conductivity of the membrane and thus to the performance of the battery.

In order to overcome this problem, a nanoporous or microporous matrix presents an attractive alternative to a gel, as such a matrix provides better interconnectivity for ionic conduction within the membrane. Earlier work focused on other methods such as phase inversion or casting of a polymer gel, whereby precise control of the porosity may be difficult. Furthermore, it may be difficult to completely remove residual solvent from within the matrix, which may affect electrochemical properties or stability of the final separator. Electrospun membranes offer an alternative with high electrolyte uptake and good homogeneity with some degree of control over the morphology of the membrane. An overview of the studies on such membranes is given in Table 9 .

The majority of the publications in this field have utilised PVdF and its copolymers, although several studies have also used polyacrylonitrile. In both cases it is generally found that the electrospun separator performs better than gel membranes or phase inversion membranes due to its high uptake of electrolyte and the interconnected conduction pathway within the membrane. A comparative study by on membranes made by electrospinning and phase inversion ${ }^{305}$ found that electrospun membranes not only have greater porosity, but also a more uniform structure and significantly higher ionic conductivity leading to better cell performance. A study on a PAN membrane separator has also shown better cycle life and thermal stability than a conventional 


\section{Cite this: DOI: 10.1039/c0xx00000x}

polyolefin microporous separator ${ }^{300}$ (see Fig. 14).

Several studies have also added inorganic additives such as $\mathrm{SiO}_{2}$ or $\mathrm{Al}_{2} \mathrm{O}_{3}$ in order to increase cell performance. Generally, addition of inorganic oxides increases the ionic conductivity of the membrane, which in some studies with PAN fibres ${ }^{302,309}$ was attributed to the smaller average fibre diameters (up to a certain inorganic content) due to the electrostatic repulsion of the inorganic particles during electrospinning, leading to membranes with greater porosity and electrolyte uptake. In contrast, other studies on PVdF-HFP 297,307 concluded that the presence of silica produced the opposite effect on fibre diameter, but a similar increase in ionic conductivity and electrolyte uptake up to a certain $\mathrm{SiO}_{2}$ content which was attributed to a decrease in PVdF crystallinity.

Another approach is the development of a multilayered composite membrane using one or more electrospun layers. A study using electrospun PVdF-CTFE $/ \mathrm{Al}_{2} \mathrm{O}_{3}{ }^{306}$ deposited on both sides of a porous polyethylene membrane shows better stability and cycling performance as the electrospun layer helps confine the electrolytes within the membrane and also increases electrolyte uptake. To decouple these effects, in another study a trilayer membrane of PVdF-HFP and PAN was fabricated through continuous electrospinning with the different polymer solutions (a PVdF-HFP layer sandwiched between two PAN layers and vice versa). The multilayered composite did not perform as well as a membrane electrospun from a solution-based blend of the two polymers, indicating that there are more beneficial interactions between them when electrospun from the same solution, resulting in a greater porosity and electrolyte uptake despite larger average fibre diameter.

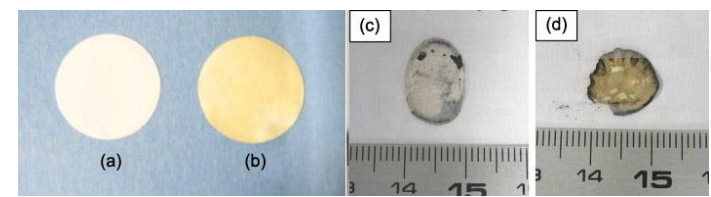

Fig. 14. Electrospun PAN nanofibre separator $(\mathrm{a}, \mathrm{b})$ and conventional polyolefin separator (c, d) before and after thermal stability tests. Reprinted from ref. 300, Copyright (2008), with permission from Elsevier.

Table 9. Studies on electrospun lithium battery separators.

\begin{tabular}{|c|c|c|c|c|c|c|}
\hline Material & $\begin{array}{l}\text { Av. fibre } \\
\text { diameter } \\
(\mathbf{n m})\end{array}$ & $\begin{array}{l}\text { Anode/cathode } \\
\text { materials }\end{array}$ & $\begin{array}{l}\text { Conductivity } \\
\left(1 \mathrm{M} \mathrm{LiPF}_{6}\right. \\
\left.\mathrm{mS} \mathrm{cm}^{-1}\right)\end{array}$ & $\begin{array}{c}\text { Discharge } \\
\text { capacity } 1^{\text {st }} \text { cycle } \\
\left(\mathbf{m A h} \mathbf{g}^{-1}\right) \text { [rate } \\
(\mathbf{C})]\end{array}$ & $\begin{array}{c}\text { Discharge } \\
\text { capacity after } \\
(\text { n) cycles } \\
\left(\mathbf{m A h g ^ { - 1 } )}\right.\end{array}$ & Ref. \\
\hline PVdF & 250 & none & 1.7 & $\mathrm{NA}^{*}$ & NA & 290 \\
\hline PVdF & 450 & $\mathrm{MCMB}^{\mathrm{a}} / \mathrm{LiCoO}_{2}$ & $>1$ & $\approx 135[0.5]$ & $\approx 135(50)$ & 291 \\
\hline PVdF-HFP & 500 & $\mathrm{MCMB} / \mathrm{LiCoO}_{2}$ & $>1$ & $\approx 150[0.5]$ & $\approx 150(\mathrm{n}=50)$ & 292 \\
\hline PAN & 330 & $\mathrm{MCMB} / \mathrm{LiCoO}_{2}$ & $>1$ & $145[0.5]$ & $136(n=150)$ & 293 \\
\hline $\begin{array}{c}\text { PVdF, PVdF- } \\
\text { HFP }\end{array}$ & 420 & $\mathrm{MCMB} / \mathrm{LiCoO}_{2}$ & 1.04 & $141[1]$ & NA & 294 \\
\hline PVdF-HFP & $1 \mu \mathrm{m}$ & $\mathrm{Li} / \mathrm{LiFePO}_{4}$ & 4.7 & $125[1]$ & $117(n=100)$ & 295 \\
\hline $\begin{array}{l}\text { PVdF- } \\
\text { HFP/IL }\end{array}$ & $\sim 700$ & $\mathrm{Li} / \mathrm{LiFePO}_{4}$ & 2.3 & $149[0.1]$ & $152(n=24)$ & 296 \\
\hline $\begin{array}{c}\text { PVdF- } \\
\mathrm{HFP} / \mathrm{SiO}_{2}\end{array}$ & $1-2 \mu \mathrm{m}$ & $\mathrm{Li} / \mathrm{LiFePO}_{4}$ & 8.06 & $170[0.1]$ & NA & 297 \\
\hline $\begin{array}{l}\text { PVdF- } \\
\text { HFP/NP }\end{array}$ & $1-5 \mu \mathrm{m}$ & $\mathrm{Li} / \mathrm{LiFePO}_{4}$ & $7.2^{\mathrm{c}}$ & $164^{\mathrm{d}}[0.1]$ & $156(n=30)$ & 298 \\
\hline $\mathrm{PI}^{\mathrm{e}}$ & $300-625$ & $\mathrm{MCMB} / \mathrm{LiNi}_{0.8} \mathrm{Co}_{0.2} \mathrm{O}_{2}$ & NA & $\sim 320[0.1]$ & $\sim 305(\mathrm{n}=21)$ & 299 \\
\hline PAN & $380 / 250$ & graphite/LiCoO ${ }_{2}$ & NA & $124.5^{\mathrm{f}}[0.5]$ & $102.7(n=250)$ & 300 \\
\hline
\end{tabular}


Cite this: DOI: 10.1039/c0xx00000x

www.rsc.org/xxxxxx

ARTICLE TYPE

\begin{tabular}{|c|c|c|c|c|c|c|}
\hline $\begin{array}{c}\text { PVdF- } \\
\mathrm{HFP} / \mathrm{SiO}_{2}\end{array}$ & $2 \mu \mathrm{m}$ & $\mathrm{Li} / \mathrm{LiFePO}_{4}$ & 4.3 & $170[0.1]$ & $160.5(n=80)$ & 301 \\
\hline $\mathrm{PAN} / \mathrm{SiO}_{2}$ & 270 & graphite/LiCoO ${ }_{2}$ & 11 & $139[0.5]$ & $127(\mathrm{n}=150)$ & 302 \\
\hline $\mathrm{PVdF}$ & $\sim 125$ & $\mathrm{Li} / \mathrm{LiFePO}_{4}$ & N/A & $177[0.1]$ & $150(\mathrm{n}=10)$ & 303 \\
\hline $\begin{array}{c}\text { PVdF- } \\
\text { HFP/PAN }^{\mathrm{g}}\end{array}$ & $320-490$ & $\mathrm{Li} / \mathrm{LiFePO}_{4}$ & $3.9-6.5$ & $145[0.1]$ & $136(n=50)$ & 304 \\
\hline PVdF-HFP & $1 \mu \mathrm{m}$ & $\mathrm{Li} / \mathrm{LiFePO}_{4}$ & 4.32 & $140[0.1]$ & $128(\mathrm{n}=50)$ & 305 \\
\hline $\begin{array}{c}\text { PVdF- } \\
\text { CTFE } / \mathrm{Al}_{2} \mathrm{O}_{3}\end{array}$ & $2-4 \mu \mathrm{m}$ & $\mathrm{MCMB} / \mathrm{LiCoO}_{2}$ & 0.49 & $143.5[0.1]$ & $131.8(n=200)$ & 306 \\
\hline $\mathrm{PVdF} / \mathrm{SiO}_{2}$ & 490 & none & 4.7 & NA & NA & 307 \\
\hline PVdF-CTFE & 230 & $\mathrm{Sn}-\mathrm{C} / \mathrm{LiNi}_{0.5} \mathrm{Mn}_{1.5} \mathrm{O}_{4}$ & $>2$ & $120[0.33]$ & $114(\mathrm{n}=10)$ & 308 \\
\hline PAN/LTO ${ }^{h}$ & 230 & $\mathrm{Li} / \mathrm{LiFePO}_{4}$ & 1.95 & $162[0.2]$ & $156(n=50)$ & 309 \\
\hline
\end{tabular}

${ }^{*} \mathrm{NA}=$ data not available. ${ }^{\mathrm{a}} \mathrm{MCMB}=$ mesocarbon microbeads. ${ }^{\mathrm{b}}$ Room temperature ionic liquids incorporated in the membrane. ${ }^{\mathrm{c}} \mathrm{Metal}$ oxide nanoparticles of $\mathrm{SiO}_{2}, \mathrm{Al}_{2} \mathrm{O}_{3}$, or $\mathrm{BaTiO}_{3}$ incorporated in the membrane. ${ }^{\mathrm{d}}$ Quoted value is of $\mathrm{BaTiO}_{3}$-containing membrane. ${ }^{\mathrm{e}} \mathrm{PI}$ used as a matrix to confine gel electrolyte containing PVdF or PAN. ${ }^{\mathrm{f}}$ Value is of PAN membrane of 380 nm fibre diameter. ${ }^{\mathrm{g}} \mathrm{Multilayered} \mathrm{composite}$ membrane. ${ }^{\text {h }} \mathrm{LTO}=$ Lanthanum titanate oxide

\section{3.d. Electrospun fibres for supercapacitors}

Electrochemical supercapacitors work by storing an

electrical charge in a metal/electrolyte interface by means of two mechanisms: electrostatic charge transfer for electrochemical double layer capacitors (EDLC) and faradaic charge transfer for pseudocapacitors310. Although the concept was industrialised a long time ago, it is undergoing renewed interests due to recent demands for energy storage devices with high power density and rapid charge/discharge rate in applications such as digital electronics and medical implants. Supercapacitors complement batteries and conventional capacitors, being used to deliver high power pulses, load-levelling or electricity storage. In an EDLC, the capacitance is determined by the surface area accessible to the electrolyte, and thus 1D nanomaterials such as carbon fibres have attracted significant attention due to their high surface $\operatorname{area}^{7}$. More recently, electrospinning has been investigated as a versatile and simple fabrication method for the highly porous, nanofibrous electrode and separator materials for supercapacitors. An overview of the developments in this area is given in Table 10

As many commercial supercapacitors are based on porous carbon ${ }^{311,312}$, several studies have focused on elaboration of electrospun carbons. The most part concerns poly(acrylonitrile) (PAN)-based precursor, such as the study by Kim et al. ${ }^{314}$ on activated carbon nanofibres (ACNF), fabricated by stabilisation and carbonisation of electrospun nanofibres obtained from this polymer, followed by activation using steam to create pores and increase the surface area of the material. Other precursors, such as $\mathrm{PBI}^{316,}{ }^{318}, \mathrm{PI}^{317}$, and isotropic pitch ${ }^{323}$ have also been reported. The performance of these ACNFs greatly depends on the activation temperature that can lead to an optimum surface area. Higher activation temperature increases the volume fraction of mesopores (even though the overall surface area may decrease at very high temperatures due to fusing of the pores), which improves the specific capacitance at high current densities due the faster transport of solvated ions enabled by mesopores ${ }^{313}$. Such carbon nanofibres can also be bonded together by the addition of a thermoplastic such as PVP to the precursor, which would partially melt during the early stages of pyrolysis and creates inter-fibre linkages.

Table 10. Electrospun materials for supercapacitors and the corresponding properties and performance.

\begin{tabular}{cccc}
\hline Material & $\begin{array}{c}\text { Fibre diameter } \\
(\mathbf{n m})\end{array}$ & $\begin{array}{c}\text { Specific surface area } \\
\left(\mathbf{m}^{\mathbf{2}} \mathbf{g}^{-\mathbf{1}}\right)\end{array}$ & $\begin{array}{c}\text { specific capacitance }\left(\mathbf{F} \mathbf{g}^{-1}\right) / \text { current }^{-1} \\
\text { density or scan rate }\end{array}$ \\
\hline PAN & 300 & $850-1230$ & $120 / 1000 \mathrm{~mA} \mathrm{~g}^{-1}$ \\
\hline
\end{tabular}




\section{Cite this: DOI: 10.1039/c0xx00000x}

\begin{tabular}{|c|c|c|c|c|}
\hline PBI & 250 & $500-1220$ & $125-178 / 4 \mathrm{~mA}$ & 316 \\
\hline PAA & $1-2 \mu \mathrm{m}$ & $900-1450$ & $175 / 1000 \mathrm{~mA} \mathrm{~g}^{-1}$ & 317 \\
\hline PAN, PBI, PI, IPP ${ }^{\mathrm{a}}$ & $50-2000$ & $1000-2500$ & $120-210 / 1000 \mathrm{~mA} \mathrm{~g}^{-1}$ & 318 \\
\hline $\mathrm{PAN} / \mathrm{ZnCl}$ & $200-350$ & $310-550$ & $120-140$ / NA & 319 \\
\hline PAN/Ag & $200-500$ & NA & $190-250$ / NA & 320 \\
\hline $\mathrm{PAN}^{\mathrm{CNNT}}{ }^{\mathrm{b}}$ & $\sim 600$ & 810 & $280 / 1000 \mathrm{~mA} \mathrm{~g}^{-1}$ & 321 \\
\hline $\mathrm{PAI}^{\mathrm{c}}$ & 350 & $1080-1360$ & $150 / 10 \mathrm{~A}$ & 322 \\
\hline PAN/IPP & 750 & $722-1724$ & $75.5-143 / 1 \mathrm{~mA} \mathrm{~cm}^{-1}$ & 323 \\
\hline PAN/Ni & 210 & NA & $164 / 200 \mathrm{~mA} \mathrm{~g}^{-1}$ & 324 \\
\hline PVP/PAN & $\sim 390-800$ & $\sim 530-810$ & 160-220 / NA & 325 \\
\hline $\mathrm{PCS}^{\mathrm{d}}$ & $\sim 3-10 \mu \mathrm{m}$ & $1740-3116$ & NA & 326 \\
\hline $\mathrm{PVP}_{\mathrm{PEDOT}}{ }^{\mathrm{e}}$ & 350 & NA & $19 / 1000 \mathrm{~mA} \mathrm{~g}^{-1}$ & 327 \\
\hline $\mathrm{TiO}_{2}-\mathrm{RuO}_{2}$ & $<1000$ & 20 & $\begin{array}{c}687 / 10 \mathrm{mV} \mathrm{s}^{-1} \\
460 / 1000 \mathrm{mV} \mathrm{s}^{-1}\end{array}$ & 331 \\
\hline $\mathrm{Pt}-\mathrm{RuO}_{2}$ & $200-300$ & NA & $\begin{array}{l}409.4 / 10 \mathrm{mV} \mathrm{s}^{-1} \\
322 / 1000 \mathrm{mV} \mathrm{s}^{-1}\end{array}$ & 334 \\
\hline $\mathrm{RuO}_{2}-\mathrm{Ag}_{2} \mathrm{O}$ & $40-70$ & NA & $173 / 10 \mathrm{mV} \mathrm{s}^{-1}$ & 332 \\
\hline $\mathrm{RuO}_{2}-\mathrm{RuO}_{2} \cdot n \mathrm{H}_{2} \mathrm{O}$ & $400-500$ & 59 & $\begin{aligned} & 886.9 / 10 \mathrm{mV} \mathrm{s}^{-1} \\
\approx & 620 / 2000 \mathrm{mV} \mathrm{s}^{-1}\end{aligned}$ & 333 \\
\hline $\begin{array}{l}\mathrm{RuO}_{2}-\mathrm{MnO}_{\mathrm{x}} \\
\text { composite mat }\end{array}$ & $\begin{array}{l}\mathrm{RuO}_{2} 400 \\
\mathrm{MnO}_{\mathrm{x}} 100\end{array}$ & NA & $208.7 / 10 \mathrm{mV} \mathrm{s}^{-1}$ & 337 \\
\hline $\mathrm{RuO}_{2}-\mathrm{Mn}_{3} \mathrm{O}_{4}$ & $150-600$ & NA & $293 / 10 \mathrm{mV} \mathrm{s}^{-1}$ & 329 \\
\hline $\mathrm{LaNiO}_{3}-\mathrm{Mn} \mathrm{O}_{\mathrm{x}}$ & $<1000$ & NA & $160 / 10 \mathrm{mV} \mathrm{s}^{-1}$ & 336 \\
\hline $\mathrm{V}_{2} \mathrm{O}_{5}$ & $500-600$ & $3-10$ & $190-250 / 5 \mathrm{mV} \mathrm{s}^{-1}$ & 328 \\
\hline $\mathrm{SnO}_{2} / \mathrm{C}$ & $400-500$ & NA & $187 / 20 \mathrm{mV} \mathrm{s}^{-1}$ & 335 \\
\hline coaxial TiN/VN & $\begin{array}{l}\text { core } 300 \\
\text { shell } 660\end{array}$ & 169 & $\begin{array}{l}247.5 / 2 \mathrm{mV} \mathrm{s}^{-1} \\
160.8 / 50 \mathrm{mV} \mathrm{s}^{-1}\end{array}$ & 338 \\
\hline
\end{tabular}

${ }^{\mathrm{a}} \mathrm{IPP}=$ isotropic pitch precursor ${ }^{b} \mathrm{CNT}=$ carbon nanotubes ${ }^{\mathrm{c}} \mathrm{PAI}=$ poly $($ amide imide $){ }^{\mathrm{d}} \mathrm{PCS}=$ polycarbomethylsilane ${ }^{\mathrm{e}} \mathrm{PEDOT}=\mathrm{poly}(3,4-$ ethylenedioxythiophene)

In order to improve the capacitance of carbon electrodes, some studies have reported the addition of components such as silver ${ }^{320}$, nickel ${ }^{324}$, or carbon nanotubes $^{321}$ (CNTs). It was found that the conductive fillers improve the capacitance of the electrode, although the exact mechanism for this effect remains unclear. The addition of CNT is believed to improve the specific capacitance by improving the conductivity of the material, the effect of which becomes more obvious at higher current densities. However, the study using a Ag additive did not show a similar correlation of conductivity and capacitance, as the capacitance continue to increase even when the conductivity remains unchanged. Other investigations have focussed on $\mathrm{ZnCl}_{2}$ as an additive, which improved the capacitance by enhancing the stabilisation and carbonisation of PAN nanofibres ${ }^{319}$. The $\mathrm{ZnCl}$ acted as a dehydrating agent, eliminating water and catalysing graphite formation. Furthermore, as it decomposed, it produced chlorine gas, which etched the carbon fibres and created micropores on their surface.

Very recently, electrospinning has also been utilised to produce a flexible supercapacitor ${ }^{327}$. The all-textile supercapacitor utilised PEDOT-coated electrospun PVP electrodes and an electrospun PAN separator. Although its performance was limited and utilised only half of the electrode capacitance, the supercapacitor assembly was fully flexible with no delamination of the layers upon bending (see Figure 15).

Pseudo-capacitors are currently attracting much attention as energy storage devices due to their high capacitances $\left(200-1300 \mathrm{~F} \mathrm{~g}^{-1}\right)$ in comparison to EDLCs $\left(50-150 \mathrm{~F} \mathrm{~g}^{-}\right.$ $\left.{ }^{1}\right)^{7}$. Transition metal oxides such as $\mathrm{RuO}_{2}, \mathrm{MnO}_{\mathbf{x}}{ }^{329}, 330$ and $\mathrm{V}_{2} \mathrm{O}_{5}{ }^{328}$ are attractive pseudo-supercapacitor electrodes, because of their several possible oxidation states, high electrical conductivity, and electrochemical stability $^{310}$.

$\mathrm{RuO}_{2}$ fulfils these requirements, and due to its high cost it is studied as nanomaterial or in composite materials. For instance, capacitors based on $\mathrm{RuO}_{2}$ electrodeposited onto electrospun $\mathrm{TiO}_{2}$ nanorods show a high rate capability (see Table 9) ${ }^{331}$. Similarly, $\mathrm{RuO}_{2}-\mathrm{Ag}_{2} \mathrm{O}$ composite nanowires produced 300\% higher capacitance compared to the single $\mathrm{RuO}_{2} \mathrm{NW}$ electrodes ${ }^{332}$.

$\mathrm{RuO}_{2}$ in its hydrated form (i.e. $\mathrm{RuO}_{2} \cdot n \mathrm{H}_{2} \mathrm{O}$ ) is a promising pseudo-capacitors material because of its high specific theoretical capacitance, high proton conductivity, and excellent electrochemical cyclability. To overcome possibly its only drawback apart from cost, the low electronic conductivity, the versatility of electrospinning in combination with other synthesis methods gives a solution, allowing to 


\section{Cite this: DOI: $10.1039 / \mathrm{c} 0 \mathrm{xx} 00000 \mathrm{x}$}

prepare conductive core fibres coated with the active material.

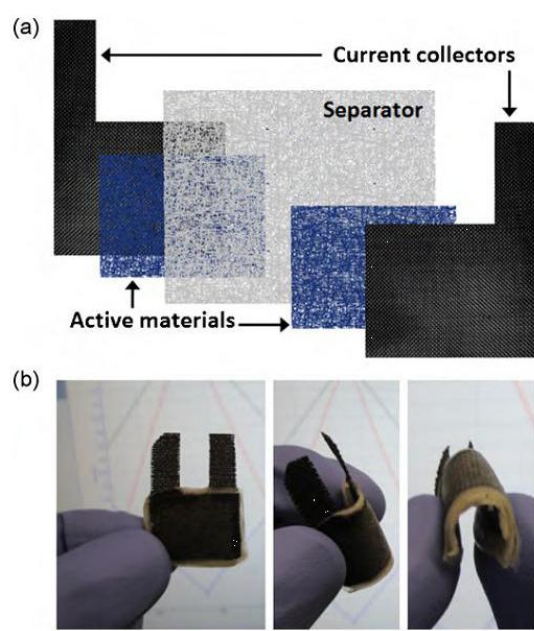

Figure 15. Schematic representation of the components in the all-textile supercapacitor (a) and photographs the flexible supercapacitor (b). Reprinted from ref. 327, Copyright (2011), with permission from Elsevier.

Electrochemical capacitors were then fabricated by depositing a thin hydrous $\mathrm{RuO}_{2}$ layer onto a crystalline $\mathrm{RuO}_{2}$ nanofibrous mat by cyclic voltammetry. Such electrodes showed a high specific capacitance $(886.9 \mathrm{~F}$ $\mathrm{g}^{-1}$ at a scan rate of $10 \mathrm{mV} \mathrm{s}^{-1}$, based on the mass of the $\mathrm{RuO}_{2} \cdot n \mathrm{H}_{2} \mathrm{O}$ coating) and high rate capability ${ }^{333}$. Highly porous and conductive electrospun $\mathrm{Pt}$ fibres were also used as core support for electrochemically deposited hydrous $\mathrm{RuO}_{2}$ overlayers ${ }^{334}$. The resulting composite electrode presented good performance with a capacity loss of only $21.4 \%$ passing from 10 to 1000 $\mathrm{mV} \mathrm{s}^{-1}$. The same strategy is also used for producing other composite materials useful in electrochemical capacitors, such as $\mathrm{SnO}_{2}$ on $\mathrm{C}$ nanofibres ${ }^{335}$ and $\mathrm{MnO}_{\mathrm{x}}$ on $\mathrm{LaNiO}_{3}$ fibre mats ${ }^{336}$.

Electrospinning is also capable of fabricating composite mats by co-depositing different materials with different properties, as in the case of layer-bylayer stacked $\mathrm{MnO}_{\mathrm{x}}-\mathrm{RuO}_{2}$, in which the first offers a facile ion pathway and the latter a fast electron pathway. The multi-stacked morphology provided high surface area and high porosity allowing an efficient permeability of the electrolyte and a good surface activity ${ }^{337}$. Coaxial electrospinning was also exploited to prepare core-sheath titanium nitridevanadium nitride fibres, which combined higher specific capacitance of $\mathrm{VN}$ and high rate capability of $\mathrm{TiN}^{338}$, exhibiting high specific capacitance and high rate capability (Table 9).

\section{Conclusions and future perspectives}

Development of new functional materials for energy-related applications with targeted nanomaterial architectures is essential to meet the performance and durability targets of energy conversion and storage applications. Along with many other avenues of research under investigation, 1D nanostructured materials are likely to significantly contribute to meeting some of these challenges as the structural control of nanomaterials can be as important as the materials themselves.

Amongst the fabrication method for nanofibres and nanowires, electrospinning is undergoing renewed intense interest and current advances indicate a high potential of electrospun materials in energy related applications. It has been established as a relatively facile method which provides researchers with great control over the fibre morphology. Electrospun nanofibrous mats show good homogeneity and porosity, and the application of electric field and stretching that occurs during electrospinning may also confer beneficial effects in certain cases, such as for ionomers.

Several challenges remain to be overcome before large scale use of electrospun materials in energyrelated applications, and this is partly due to the fact that the process parameters affecting the electrospinning technique are still not fully understood. Thus, there are still limitations on the type of materials that can be synthesised by electrospinning, and it may be difficult to fully eliminate defects such as beads and obtain completely homogeneous nanofibres. For applications such as nanofibrous catalysts and supports, supplementary developments will be needed should further reduction of fibre diameters be required. Additional challenges are related to scale-up of electrospinning and downstream processing, these being essential steps for the introduction of electrospun materials in industrial application in energy devices. Progress with multi-jet emitters/nozzles increases both productivity and cover area of large scale nanofibre production ${ }^{339}, \quad 340$ Furthermore, although advances in aligning and bridging adjacent fibres have been made, still further solutions must be found to temper the fragility of ceramic electrospun nanofibre networks, for which elimination of the carrier polymer while maintaining fibre integrity and composition represent additional challenges that can impede transfer to the target application.

Despite the challenges, electrospinning has been shown to be capable of producing nanofibre mats of excellent uniformity and further developments have 


\section{Cite this: DOI: 10.1039/c0xx00000x}

brought about more complex architectures such as core-shell and hollow fibres by coaxial electrospinning, as well as novel composite materials by the use of co-electrospinning. As we look for solutions to meet new technological requirements, electrospinning is emerging as one of the principal methods in the synthesis of nanofibres as it is a powerful and versatile technique which would be relatively simple to scale-up and which appears attractive from an industrial perspective.

\section{Acknowledgements}

Funding from the European Community's Seventh Framework Programme (FP7/2010-2013) within the Future Emerging Technologies for Energy Applications (FET) programme under the project QuasiDry (contract 256821) is acknowledged. SC thanks the Conseil Scientifique de l'Université Montpellier 2 for financial support under its Programme Blanc.

\section{Abbreviations}

$\begin{array}{ll}\text { 1D } & \text { One-dimensional } \\ \text { NF } & \text { Nanofibre } \\ \text { NW } & \text { Nanowire } \\ \text { NR } & \text { Nanorod } \\ \text { NP } & \text { Nanoparticle } \\ \text { FC } & \text { Fuel cell } \\ \text { DSC } & \text { Dye-sensitised solar cell } \\ \text { LIB } & \text { Li-ion battery } \\ \text { CNF } & \text { Carbon nanofibres } \\ \text { CFM } & \text { Carbon fibrous mat } \\ \text { PEMFC } & \text { Proton exchange membrane fuel cell } \\ \text { AFC } & \text { Alkaline fuel cell } \\ \text { DMFC } & \text { Direct methanol fuel cell } \\ \text { DAFC } & \text { Direct alcohol fuel cell } \\ \text { DFAFC } & \text { Direct formic acid fuel cell } \\ \text { SOFC } & \text { Solid oxide fuel cell } \\ \text { ECSA } & \text { Electrochemical surface area } \\ \text { ORR } & \text { Oxygen reduction reaction } \\ \text { MOR } & \text { Methanol oxidation reaction }\end{array}$

\section{Notes and references}

${ }^{a}$ Institut Charles Gerhardt, UMR CNRS 5253, Laboratoire des Agrégats Interfaces et Matériaux pour l'Energie, Université Montpellier 2 -34095 Montpellier Cedex 5, France. Fax: +33 (0)4 671433 04; Tel: +33 (0)4 671490 98; E-mail: sara.cavaliere@univ-montp2.fr
PFSA Perfluorosulfonic acid

PAN Poly(acrylonitrile)

PVA Poly(vinyl alcohol)

PEO Poly(ethylene oxide)

CTAB Cetyl trimethylammonium bromide

DMAc Dimethylacetamide

sPOSS Polyhedral oligomeric silsesquioxane

PWA Phosphotungstic acid

BPPO Bromomethylated sulfonated polyphenylene oxide

SPPO Sulfonated Poly(2,6-dimethyl-1,4-phenylene oxide)

poly $\left(\mathrm{MEBIm}-\mathrm{BF}_{4}\right)$

Poly(1-(2-methacryloyoxy)ethyl-3-

butylimidazolium tetrafluoroborate

$\mathrm{MeCN}$ Acetonitrile

DMAc N,N-dimethylacetamide

DMF N,N-dimethylformamide

IPA Isopropyl alcohol (2-propanol)

PMMA Polymethylmethacrylate

PVdF Polyvinylidenefluoride

PVdF-HFP

Poly(vinylidenefluoride-co-

PVdF-CTFE

hexafluoropropylene)

Poly(vinyledenefluoride-co-

chlorotrifluoroethylene)

PI Polyimide

PS Polystyrene

PVAc Polyvinylacetate

AM Air-mass

$\mathrm{V}_{\mathrm{oc}} \quad$ Open-circuit voltage

$\mathrm{J}_{\mathrm{sc}} \quad$ Short-circuit current density

FF Fill factor

$\eta \quad$ Light-to-electricity conversion efficiency

$\mathrm{R}_{\mathrm{ct}} \quad$ Charge-transfer resistance

TCO Transparent conducting oxide

ITO Indium tin oxide

FTO Fluorine-doped tin oxide

SEI Solid-electrolyte interface

LiPON Lithium phosphorous oxynitride

EDLC Electrochemical double layer capacitors

ACNF Activated carbon nanofibres

CNT Carbon nanotubes

${ }^{1}$ P. G. Bruce, B. Scrosati and J.-M. Tarascon, Angew. Chem. Int. Ed., 2008, 47, 2930-2946.

${ }^{2}$ J. Cabana, L. Monconduit, D. Larcher and M. R. Palacín, $A d v$. Mater., 2010, 22, E170-E192.

${ }^{3}$ J.-M. Tarascon, N. Recham, M. Armand, J.-N. Chotard, P. Barpanda, W. Walker and L. Dupont, Chem. Mater., 2010, 22, 724-739. 


\section{Cite this: DOI: 10.1039/c0xx00000x}

${ }^{4}$ P. J. Hall, M. Mirzaeian, S. I. Fletcher, F. B. Sillars, A. J. R. Rennie, G. O. Shitta-Bey, G.Wilson, A.Cruden and R. Carter, Energy Environ. Sci., 2010, 3, 1238-1251.

${ }^{5}$ C. Xu, F. Kang, B. Li and H. Du, J. Mater. Res., 2010, 25, 1421-1432.

${ }^{6}$ L. L. Zhang and X. S. Zhao, Chem. Soc. Rev., 2009, 3825202531.

${ }^{7}$ P. Simon and Y. Gogotsi, Nat. Mater., 2008, 7, 845-854.

${ }^{8}$ F. Beguin and E. Frackowiak, in Adsorption by Carbons, eds. J. E. Bottani and J. M. D. Tascon, 2008, pp. 593-629.

9 D. J. Jones and J. Rozière, Adv. Polym. Sci., 2008, 215 (Fuel Cells I), 219-264.

${ }^{10}$ J. Suntivich, H. A. Gasteiger, N. Yabuuchi, H. Nakanishi, J. B. Goodenough and Y. Shao-Horn, Nat. Chem., 2011, 3, 546550.

${ }^{11}$ A. S. Aricò, V. Baglio and V. Antonucci, in Nanotechnology for the Energy Challenge, eds J. Garcia-Martinez, 2010, pp. 79-109.

12 Y.A. Elabd and M.A. Hickner, Macromolecules, 2011, 44, 111

${ }^{13}$ D. Thompsett, in Proton Exchange Membrane Fuel Cells, eds. D.P. Wilkinson, 2010, pp.1-60.

14 Z. Ning, Y. Fu and H. Tian, Energy Environ. Sci., 2010, 3, 1170-1181.

15 J. Preat, D. Jacquemin and E. A. Perpete, Energy Environ. Sci., 2010, 3, 891-904.

${ }^{16}$ J. Nei de Freitas, A. F. Nogueira and M.-A. De Paoli, $J$. Mater. Chem., 2009, 19, 5279-5294.

${ }^{17}$ M. Grätzel, Acc. Chem. Res., 2009, 42, 1788-1798.

${ }^{18}$ Y. Xia, P. Yang, Y. Sun, Y. Wu, B. Mayers, B. Gates, Y. Yin, F. Kim and H. Yan, Adv. Mater., 2003, 15, 353-389.

${ }^{19}$ L. C. Palmer and S. I. Stupp, Acc. Chem. Res., 2008, 41, 16741684.

${ }^{20}$ A. I. Hochbaum, R. Chen, R. D. Delgado, W. Liang, E. C. Garnett, M. Najarian, A. Majumdar, and P. Yang, Nature, 2008, 451,163-167.

${ }^{21}$ S. Barth, F. Hernandez-Ramirez, J. D. Holmes and A. Romano-Rodriguez, Prog. Mater. Sci., 2010, 55, 563-627.

${ }^{22}$ See a special issue in Adv. Mater. 2003, 15, 351-456.

${ }^{23} \mathrm{D}$. Li and Y. Xia, Adv. Mater., 2004, 16, 1151-1170.

${ }^{24}$ D. H. Reneker, A. L. Yarin, E. Zussman, and H. Xu, $A d v$. Appl. Mech., 2007, 41, 43-195.

${ }^{25}$ A. L. Yarin, E. Zussman, J. H. Wendorff, and A. Greiner, $J$. Mater. Chem., 2007, 17, 2585-2599.

${ }^{26}$ D.H. Reneker and A.L. Yarin, Polymer, 2008, 49, 2387-2425.

${ }^{27}$ A. L. Yarin, Polym. Adv. Tech., 2011, 22, 310-317.

${ }^{28}$ V. Thavasi, G. Singh and S. Ramakrishna, Energy Environ. Sci., 2008, 1, 205-221.

${ }^{29}$ Y. Dai, W. Liu, E. Formo, Y. Sun and Y. Xia, Polym. Adv. Technol., 2011, 22, 326-338.

${ }^{30}$ A. Frenot and I. S. Chronakis, Curr. Opin. Coll. Interface Sci., 2003, 8, 64-75.

${ }^{31}$ R. Ramaseshan, S. Sundarrajan, R. Jose and S. Ramakrishna, J. Appl. Phys., 2007, 102, 111101-111117.

${ }^{32}$ I. S. Chronakis, J. Mater. Process. Tech., 2005, 167, 283-293.

${ }^{33}$ W. E. Teo and S. Ramakrishna, Nanotechnology, 2006, 17, R89-R106.

${ }^{34}$ G. Taylor, Proc. Roy. Soc. Lond. A, 1969, 313, 453-475.

${ }^{35}$ J. Zeleny, Phys. Rev., 1914, 3, 69-91.

${ }^{36}$ A. Formhals, US 1975504, 1934.

${ }^{37}$ J. Doshi and D. H. Reneker, J. Electrost., 1995, 35, 151-160.

${ }^{38}$ C. P. Bean, J. D. Livingston, J. Appl. Phys.,1959, 30, S120S129.

${ }^{39}$ M.-C. Daniel, D. Astruc, Chem. Rev., 2004, 104, 293-346.
${ }^{40}$ Z.-Y. Zhou, N. Tian, J.-T. Li, I. Broadwell and S.-G. Sun, Chem. Soc. Rev., 2011, 40, 4167-4185.

${ }^{41}$ Y. Ner, J. G. Grote, J. A. Stuart and G. A. Sotzing, Angew. Chem. Int. Ed., 2009, 48, 5134-5138.

${ }^{42}$ S. Cavaliere, V. Salles, A. Brioude, Y. Lalatonne, L. Motte, P. Monod, D. Cornu and P. Miele, J. Nanoparticle Res., 2010, 12, 2735-2740.

${ }^{43}$ E. Jo, S. Lee, K. T. Kim, Y. S. Won, H.-S. Kim, E. C. Cho and U. Jeong, Adv. Mater., 2009, 21, 968-972.

${ }^{44}$ D. Navarathne, Y. Ner, M. Jain, J. G. Grote and G. A. Sotzing, Mater. Lett., 2010, 65, 219-221.

${ }^{45}$ S. A. Theron, E. Zussman and A. L. Yarin, Polymer, 2004, 45, 2017-2030.

${ }^{46}$ N. Bhardwaj and S. C. Kundu, Biotechnol. Adv., 2010, 28, 325-347.

${ }^{47}$ L. S. Carnell, E. J. Siochi, R. A. Wincheski, N. M. Holloway and R. L. Clark, Scripta Mater., 2009, 60, 359-361.

${ }^{48}$ Q. Yu, M. Wang and H. Chen, Mater. Lett., 2010, 64, 428430.

${ }^{49}$ Z. Sun, E. Zussman, A. L. Yarin, J. H. Wendorff and A. Greiner, Adv. Mater., 2003, 15, 1929-1932.

${ }^{50}$ D. Li and Y. Xia, Nano Lett., 2004, 4, 933-938.

${ }^{51}$ E. Zussman, A. L. Yarin, A. V. Bazilevsky, R. Avrahami and M. Feldman, Adv. Mater., 2006, 18, 348-353.

${ }^{52}$ A.V. Bazilevsky, A. L. Yarin, and C. M. Megaridis, Langmuir, 2007, 23, 2311-2314

53 J. T. McCann, D. Li and Y. Xia, J. Mater. Chem., 2005, 15, 735-738.

${ }^{54}$ Y. Zhao, X. Cao and L. Jiang, J. Am. Chem. Soc., 2007, 129, 764-765.

${ }^{55}$ T. Zhao, Z. Liu, K. Nakata, S. Nishimoto, T. Murakami, Y. Zhao, L. Jiang and A. Fujishima, J. Mater. Chem., 2010, 20, 5095-5099.

${ }^{56}$ D. Li, J. T. McCann and Y. Xia, Small, 2005, 1, 83-86.

${ }^{57}$ R. Jalili, M. Morshed, S. Abdolkarim, H. Ravindi, J. Appl. Polym. Sci. 2006, 101, 4350-4357

${ }^{58}$ A. M. dos Santos, J. Dierck, M. Troch, M. Podevijn, E. Schact, Macromol. Mater. Eng. 2011, 296, 637-644

${ }^{59}$ H. Pan, L. Li, L. Hu, X. Cui, Polymer, 2006, 47, 4901-4904

${ }^{60}$ Y. Qiu, J. Yu, J. Rafique, J. Yin, X. Bai, E. Wang, J. Phys. Chem. C, 2009, 113, 11228

${ }^{61}$ F.-L. Zhou, R.-H. Gong and I. Porat, Polym. Int., 2009, 58, 331-342.

${ }^{62}$ G. Hota, B. R. Kumar, W. J. Ng and S. Ramakrishna, J. Mater. Sci., 2008, 43, 212-217.

${ }^{63}$ M. Roso, S. Sundarrajan, D. Pliszka, S. Ramakrishna and M. Modesti, Nanotechnology, 2008, 19, 285707-285712.

${ }^{64}$ Y.-J. Zhang, Y.-D. Huang, L. Wang, F.-F. Li, G.-F. Gong, Mater. Chem. Phys., 2005, 91, 217-222.

${ }^{65}$ K. Sawicka and P. Gouma, J. Nanopart. Res., 2006, 8, 769781.

${ }^{66}$ E. Formo, M. S. Yavuz, E. P. Lee, L. Lane and Y. Xia, $J$. Mater. Chem., 2009, 19, 3878-3882.

${ }^{67}$ Y. Ding, Y. Wang, L. Zhang, H. Zhang, C. M. Li and Y. Lei, Nanoscale, 2011, 3, 1149-1157.

${ }^{68}$ S. K. Choi, S. Kim, S. K. Lim and H. Park, J. Phys. Chem. C, 2010, 114, 16475-16480

${ }^{69}$ M. Zhang, C. Shao, Z. Guo, Z. Zhang, J. Mu, T. Cao and Y. Liu, ACS Appl. Mater. Interfaces, 2011, 3, 369-377.

${ }^{70}$ H. M. Kim, W.-P. Chae, K.-W. Chang, S. Chun, S. Kim, Y. Jeong and I.-K. Kang, J. Biomed. Mater. Res. Part B: Appl. Biomater., 2010, 94B, 380-387.

${ }^{71}$ J. Miao, M. Miyauchi, T. J. Simmons, J. S. Dordick and R. J. Linhardt, J. Nanosci. Nanotechnol., 2010, 10, 5507-5519. 


\section{Cite this: DOI: $10.1039 / \mathrm{c0xx00000x}$}

${ }^{72}$ Z. Dong, S. J. Kennedy and Y. Wu, J. Power Sources, 2011, 196, 4886-4904

73 D. J. Jones and J. Rozière, in Encyclopedia of Electrochemical Power Sources Vol. 2, eds C. D. J. Garche, P. Moseley, B. Scrosati, Z. Ogumi, and D. Rand, Elsevier, Amsterdam, 2009, pp. 667-679.

${ }^{74}$.B. Lafitte and P. Jannasch, Adv. Fuel Cells, 2007, 1, 119-185.

${ }^{75}$ M.L. Einsla, Y.S. Kim, M.Hawley, H-S. Lee, J.E. McGrath, B. Liu, M.D. Guiver, and B.S. Pivovar, Chem. Mater, 2008, 20, 5636-5642.

${ }^{76}$ M. Schuster; T. Rager; A. Noda, K. D. Kreuer; J. Maier, Fuel Cells, 2005, 5, 355-365.

77 D. Thompsett, in Proton Exchange Membrane Fuel Cells, Materials Properties and Performance, Eds. D. P. Wilkinson, J. Zhang, R. Hui, J. Fergus, and X. Li, CRC Press, 2010, pp 2-60.

${ }^{78}$ H.A. Gasteiger, D.R. Baker, R.N. Carter, W. Gu, Y. Liu, F.T. Wagner, P.T. Yu, in Hydrogen and Fuel Cells eds. D. Stolten, 2010, pp. 3-16.

${ }^{79}$ K. Sasaki, F. Takasaki, Z. Noda, S. Hayashi, Y. Shiratori, and K. Ito, ECS Trans. , 2010, 473-482.

80 Y. Shao, J. Liu, Y. Wang, and Y. Lin, J. Mater. Chem., 2009, 19, 46-59.

${ }^{81}$ J. Zhang, M. B. Vukmirovic, K. Sasaki, A. U. Nilekar, M. Mavrikakis, and R. R. Adzic, Electrochim. Acta, 2005, 52, 2257-2263.

${ }^{82}$ P. Strasser, K. Shirlaine, T. Anniyev, J. Greeley, K. More, C. Yu, Z. Liu, S. Kaya, D. Nordlund, H. Ogasawara, M.F. Toney, and A. Nilsson, Nat. Chem., 2010, 2, 454-460.

${ }^{83}$ M.K. Debe, A.J. Steinbach, G.D. Vernstrom, S.M. Hendricks, M.J. Kurkowski, R.T. Atanasoski, P. Kadera, D.A. Stevens, R.J. Sanderson, E. Marvel, and J.R. Dahn,, J. Electrochem. Soc., 2011, 158, B910-B918.

${ }^{84}$ H. Yang, Angew. Chem., Int. Ed., 2011, 50, 2674-2676.

${ }^{85}$ Y. Yang, A. Siu, T.J. Peckham, and S. Holdcroft, Adv. Polym. Sci., 2008, 215, 55-126.

${ }^{86}$ M. Lee, J.K. Park, H-S. Lee, O. Lane, R.B. Moore, J.E. McGrath, and D.G. Baird, Polymer, 2009, 50, 6129-6138.

${ }^{87}$ Y. Zhou, K. Neyerlin, T.S. Olson, S. Pylypenko, J. Bult, H.N. Dinh, T. Gennett, Z. Shao, and R'O. Hayre, Energy Environ. Sci. 2010, 3, 1437-1446.

${ }^{88}$ W. Zhang, P. Sherrell, A.I. Minett, J.M. Razal, and J. Chen, En. Environ. Sci., 2010, 3, 1286-1293.

${ }^{89}$ S. Cavaliere, S. Subianto, L. Chevallier, D. J. Jones, and J. Rozière, Chem. Commun., 2011, 47, 6834-6836.

${ }^{90}$ S-Y. Huang, P. Ganesan, and B.N. Popov, App. Cat. B: Environ., 2011, 102, 71-77.

${ }^{91}$ J. Bernard d'Arbigny, G. Taillades, M. Marrony, D. J. Jones, and J. Rozière, Chem. Commun., 2011, 47, 7950- 7952

${ }^{92}$ J.-M. Kim, H.-I. Joh, S.-M. Jo, D.-J. Ahn, H.-Y. Ha, S.-A. Hong and S.-K. Kim, Electrochim. Acta, 2010, 55, 48274835.

${ }^{93}$ H. J. Kim, Y. S. Kim, M. H. Seo, S. M. Choi and W. B. Kim, Electrochem. Comm., 2009, 11, 446-449.

${ }^{94}$ Y. S. Kim, S. H. Nam, H.-S. Shim, H.-J. Ahn, M. Anand and W. B. Kim, Electrochem. Comm., 2008, 10, 1016-1019.

${ }^{95}$ H. J. Kim, Y. S. Kim, M. H. Seo, S. M. Choi, J. Cho, G. W. Huber and W. B. Kim, Electrochem. Comm., 2010, 12, 3235.

${ }^{96}$ J.-L. Shui, J.-W. Zhang and J. C. M. Li, J. Mater. Chem., 2011, 21, 6225-6229.

${ }^{97}$ J. Shui and J. C. M. Li, Nano Lett., 2009, 9, 1307-1314.

98 J.-1. Shui, C. Chen and J. C. M. Li, Adv. Funct. Mater., 2011, 21, 3357-3362.
${ }^{99}$ L. Su, W. Jia, A. Schempf, Y. Ding and Y. Lei, J. Phys. Chem. $C, 2009,113,16174-16180$

${ }^{100}$ S. G. Chalk and J. F. Miller, J. Power Sources, 2006, 159, 73 80.

${ }^{101}$ S.H. Joo, S. J. Choi, I. Oh, J. Kwak, Z. Liu, O. Terasaki and R. Ryoo, Nature, 2001, 412, 169.

102 C. Tekmen, Y. Tsunekawa and H. Nakanishi, J. Mater. Process. Technol, 2010, 210, 451-455.

${ }^{103}$ S. Imaizumi, H. Matsumoto, K. Suzuki, M. Minagawa, M. Kimura,and A. Tanioka, Polymer Journal, 2009, 41, 11241128.

${ }^{104}$ P. Hiralal, S. Imaizumi, H. E. Unalan, H. Matsumoto, M. Minagawa, M. Rouvala, A. Tanioka and G. A. J. Amaratunga, ACS Nano, 2010, 4, 2730-2734

${ }^{105}$ J.-H. Park, Y.-W. Ju, S.-H. Park, H.-R. Jung, K.-S. Yang and W.-J. Lee, J. Appl. Electrochem., 2009, 39, 1229-1236.

106 S. K. Nataraj, B. H. Kim, J. H. Yun, D. H. Lee, T. M. Aminabhavi and K. S. Yang, Synth. Met., 2009, 159, 14961504.

${ }^{107}$ S. K. Nataraj, B. H. Kim, J. H. Yun, D. H. Lee, T. M. Aminabhavi and K. S. Yang, Mater. Sci. Eng. B, 2009, 162, 75-81.

${ }^{108}$ B. Jeong, S. Uhm and J. Lee, ECS Trans., 2010, 33, $1757-$ 1767.

${ }^{109}$ M. Li, S. Zhao, G. Han and B. Yang, J. Power Sources, 2009, 191, 351-356.

${ }^{110}$ M. Li, G. Han and B. Yang, Electrochem. Comm., 2008, 10, 880-883.

${ }^{111}$ X. Liu, M. Li, G. Han and J. Dong, Electrochim. Acta, 2010, 55, 2983-2990.

${ }^{112}$ Z. Lin, L. Ji, W. E. Krause and X. Zhang, J. Power Sources, $2010,195,5520-5526$

${ }^{113}$ N. T. Xuyen, H. K. Jeong, G. Kim, K. P. So, K. H. An and Y. H. Lee, J. Mater. Chem., 2009, 19, 1283-1288.

114 Z. Lin, L. Ji and X. Zhang, Electrochim. Acta, 2009, 54, 7042-7047.

${ }^{115}$ Z. Lin, L. Ji, O. Toprakci, W. Krause and X. Zhang, J. Mater. Res., 2010, 25, 1329-1335.

${ }^{116}$ J. Huang, H. Hou and T. You, Electrochem. Comm., 2009, 11, 1281-1284.

${ }^{117}$ R. Borup, J. Meyers, B. Pivovar, Y. S. Kim, R. Mukundan, N. Garland, D. Myers, M. Wilson, F. Garzon, D. Wood, P. Zelenay, K. More, K. Stroh, T. Zawodzinski, J. Boncella, J. E. McGrath, M. Inaba, K. Miyatake, M. Hori, K. Ota, Z. Ogumi, S. Miyata, A. Nishikata, Z. Siroma, Y. Uchimoto, K. Yasuda, K.-i. Kimijima and N. Iwashita, Chem. Rev., 2007, 107, 3904-3951.

${ }^{118}$ K.-W. Park, K.-S. Seol, Electrochem. Comm., 2007, 9, 2256.

${ }^{119}$ B. J. Eastwood, P. A. Christensen, R. D. Armstrong and N. R. Bates, J. Solid State Electrochem., 1999, 3, 179-186.

${ }^{120}$ K. Hartl, M. Hanzlik and M. Arenz, Energy Environ. Sci., 2011, 4, 234-238.

${ }^{121}$ X. Wang, W. Li, Z. Chen, M. Waje, Y. Yan, J. Power Sources, 2006, 158, 154.

${ }^{122}$ P. J. Ferreira, G. J. la O, Y. Shao-Horn, D. Morgan, R. Makharia, S. Kocha and H. A. Gasteiger, J. Electrochem. Soc., 2005, 152, A2256-A2271.

123 E. Passalacqua, P. L. Antonucci, M. Vivaldi, A. Patti, V. Antonucci, N. Giordano and K. Kinoshita, Electrochim. Acta, 1992, 37, 2725-2730.

${ }^{124}$ S. Shanmugam and A. Gedanken, J. Phys. Chem. C, 2009, 113, $18707-18712$

${ }^{125}$ S.-Y. Huang, P. Ganesan and B. N. Popov, Appl. Cat. B, 2011, 102, 71-77. 


\section{Cite this: DOI: 10.1039/c0xx00000x}

${ }^{126}$ S. L. Gojkovic, B. M. Babic, V. R. Radmilovic and N. V. Krstajic, J. Electroanal. Chem., 2010, 639, 161-166.

${ }^{127}$ B. Seger, A. Kongkanand, K. Vinodgopal and P. V. Kamat, $J$. Electroanal. Chem., 2008, 621, 198-204.

${ }^{128}$ N. R. Elezovic, B. M. Babic, V. R. Radmilovic, L. M. Vracar and N. V. Krstajic, Electrochim. Acta, 2009, 54, 2404-2409.

${ }^{129}$ P. Kulesza, K. Miecznikowski, B. Baranowska, M. Skunik, A. Kolary-Zurowska, A. Lewera, K. Karnicka, M. Chojak, I. Rutkowska, S. Fiechter, P. Bogdanoff, I. Dorbandt, G. Zehl, R. Hiesgen, E. Dirk, K. Nagabhushana and H. Boennemann, J. Appl. Electrochem., 2007, 37, 1439-1446.

${ }^{130}$ F. Ettingshausen, A. Weidner, S. Zils, A. Wolz, J. Suffner, M. Michel and C. Roth, ECS Trans., 2009, 25, 1883-1892.

${ }^{131}$ J. Bernard d'Arbigny, G. Taillades, M. Marrony, D. J. Jones, J. Rozière, Chem. Commun., 2011, 47, 7950-7952.

${ }^{132}$ D. Ham and J. Lee, Energies, 2009, 2, 873-899.

${ }^{133}$ M. Pourbaix, Atlas of electrochemical equilibria in aqueous solutions, National Association of Corrosion Engineers, Houston, TX, 1974.

${ }^{134}$ L. Xiong and A. Manthiram, Electrochim. Acta, 2004, 49, 4163-4170.

${ }^{135}$ M. S. Saha, M. N. Banis, Y. Zhang, R. Li, X. Sun, M. Cai and F. T. Wagner, J. Power Sources, 2009, 192, 330-335.

136 A. Bauer, C. Song, A. Ignaszak, R. Hui, J. Zhang, L. Chevallier, D. J. Jones and J. Rozière, Electrochim. Acta, 2010, 55, 8365-8370.

${ }^{137}$ S. Beak, D. Jung, K. Nahm and P. Kim, Catal. Lett., 2010, 134, 288-294.

${ }^{138}$ S. Shanmugam, A. Gedanken, Small, 2007, 7, 1189-1193.

${ }^{139}$ S. J. Tauster, Acc. Chem. Res., 1987, 20, 389-394.

${ }^{140}$ Y.-J. Seol, K.-H. Kim, I. A. Kim and S.-H. Rhee, J. Biomed. Mater. Res., 2010, 94A, 649-659.

${ }^{141}$ A. F. Lotus, E. T. Bender, E. A. Evans, R. D. Ramsier, D. H. Reneker and G. G. Chase, J. Appl. Phys., 2008, 103, 024910-024916.

${ }^{142}$ S.-Y. Huang, P. Ganesan and B. N. Popov, Appl. Cat. B, 2011, 102, 71-77.

${ }^{143}$ T. B. Do, M. Cai, M. S. Ruthkosky and T. E. Moylan, Electrochim. Acta, 2010, 55, 8013-8017.

${ }^{144}$ F. M. B. Hassan, H. Nanjo, S. Venkatachalam, M. Kanakubo and T. Ebina, J. Power Sources, 2010, 195, 5889-5895.

145 B.E. Hayden, D.V. Malevich, D. Pletcher, Electrochem. Comm., 2001, 3, 390-394.

146 N. R. Elezović, B. M. Babić, L. Gajic-Krstajić, V. Radmilović, N. V. Krstajić and L. J. Vračar, J. Power Sources, 2010, 195, 3961-3968.

${ }^{147}$ C. Subban, Q. Zhou, B. Leonard, C. Ranjan, H. M. Edvenson, F. J. Di Salvo, S. Munie and J. Hunting, Phil. Trans. R. Soc. A, 2010, 368, 3243-3253.

${ }^{148}$ T. Ioroi, Z. Siroma, N. Fujiwara, S. Yamazaki and K. Yasuda, Electrochem. Comm., 2005, 7, 183-188.

${ }^{149}$ G. Chen, S. R. Bare and T. E. Mallouk, J. Electrochem. Soc., 2002, 149, A1092-A1099.

${ }^{150}$ E. Formo, Z. Peng, E. Lee, X. Lu, H. Yang and Y. Xia, J. Phys. Chem. C, 2008, 112, 9970-9975.

${ }^{151}$ A. Bauer, C. Song, Y. Xie, J. Zhang and R. Hui, J. Power Sources 2010, 195, 3105-3110.

${ }^{152}$ Q. Long, M. Cai, J. Li, H. Rong and L. Jiang, J. Nanopart. Res., 2011, 13, 1655-1662.

${ }^{153}$ L. Su, W. Jia, A. Schempf and Y. Lei, Electrochem. Comm., 2009, 11, 2199-2202

${ }^{154}$ S. Kim, S. K. Choi, S. K. Lim, D. Chang and H. Park, Cryst. Res. Technol., 2010, 45, 1079-1082.
${ }^{155}$ A. García-Márquez, D. Portehault and C. Giordano, J. Mater. Chem., 2011, 21, 2136-2143.

${ }^{156}$ H. Zhong, X. Chen, H. Zhang, M. Wang and S. S. Mao, Appl. Phys. Lett., 2007, 91, 163103.

${ }^{157}$ A.-M. Azad, T. Matthews and J. Swary, Mater. Sci. Eng. B, 2005, 123, 252-258

${ }^{158}$ M. Zhi, N. Mariani, K. Gerdes and N. Wu, ECS Trans., 2011, 35, 2201-2207.

${ }^{159}$ L. Li, P. Zhang, R. Liu and S. M. Guo, J. Power Sources, 2011, 196, 1242-1247.

${ }^{160}$ S. Shahgaldi, Z. Yaakob, D. J. Khadem, M. Ahmadrezaei and W. R. W. Daud, J. Alloys Compd., 2011, 509, 9005-9009.

${ }^{161}$ S. Sinha-Ray, A. L. Yarin and B. Pourdeyhimi, Carbon, 2010, 48, 3575-3578.

${ }^{162}$ S. Chen, H. Hou, F. Harnisch, S. A. Patil, A. A. CarmonaMartinez, S. Agarwal, Y. Zhang, S. Sinha-Ray, A. L. Yarin, A. Greiner and U. Schroder, Energy Environ. Sci., 2011, 4, 1417-1421.

${ }^{163}$ M. Li, Y. Chang, G. Han and B. Yang, J. Power Sources, 2011, 196, 7973-7978.

${ }^{164}$ S. Molla and V. Compan, J. Membr. Sci., 2011, 372, 191-200.

${ }^{165}$ S. Molla and V. Compan, J. Power Sources, 2011, 196, 26992708.

166 H. L. Lin, S. H. Wang, C. K. Chiu, T. L. Yu, L. C. Chen, C. C. Huang, T. H. Cheng and J. M. Lin, J. Membr. Sci., 2010, 365, 114-122

${ }^{167}$ S. Molla, V. Compan, E. Gimenez, A. Blasquez, and I. Urdanpilleta Int. J. Hydrogen Energy., 2011, 36, 98869895.

${ }^{168}$ S. W. Choi, Y. Z. Fu, Y. R. Ahn, S. M. Jo and A. Manthiram, J. Power Sources, 2008, 180, 167-171.

${ }^{169}$ M. M. Hasani-Sadrabadi, I. Shabani, M. Soleimani and H. Moaddel, J. Power Sources, 2011, 196, 4599-4603.

${ }^{170}$ I. Shabani, M. M. Hasani-Sadrabadi, V. Haddadi-Asl and M. Soleimani, J. Membr. Sci., 2011, 368, 233-240.

${ }^{171}$ R. Takemori and H. Kawakami, J. Power Sources, 2010, 195 , 5957-5961.

${ }^{172}$ S. H. Yun, J. J. Woo, S. J. Seo, L. Wu, D. Wu, T. Xu and S. H. Moon, J. Membr. Sci., 2011, 367, 296-305.

${ }^{173} \mathrm{H}$. Chen, J. D. Snyder and Y. A. Elabd, Macromolecules, 2008, 41, 128-135.

174 A. Laforgue, L. Robitaille, A. Mokrini and A. Ajji, Macromol. Mater. Eng., 2007, 292, 1229-1236.

${ }^{175}$ B. Dong, L. Gwee, D. Salas-de la Cruz, K. I. Winey and Y. A. Elabd, Nano Lett., 2010, 10, 3785-3790.

${ }^{176}$ C. Pan, H. Wu, C. Wang, B. Wang, L. Zhang, Z. Cheng, P. Hu, W. Pan, Z. Zhou, X. Yang and J. Zhu, Adv. Mater.,2008, 20, 1644-1648.

177 J. B. Ballengee and P. N. Pintauro, J. Electrochem. Soc., 2011, 158, B568-B572.

${ }^{178}$ R. Bajon, S. Balaji and S. M. Guo, J. Fuel Cell Sci. Technol., 2009, 6, 031004/1-031004/6.

${ }^{179}$ J. Choi, K. M. Lee, R. Wycisk, P. N. Pintauro and P. T. Mather, J. Mater. Chem., 2010, 20, 6282-6290.

${ }^{180}$ J. Choi, R. Wycisk, W. Zhang, P. N. Pintauro, K. M. Lee and P. T. Mather, ChemSusChem, 2010, 3, 1245-1248.

${ }^{181}$ H. Chen and Y. A. Elabd, Macromolecules, 2009, 42, 33683373.

${ }^{182}$ X. Li, X. Hao, D. Xu, G. Zhang, S. Zhong, H. Na and D. Wang, J. Membr. Sci., 2006, 281, 1-6.

${ }^{183}$ P. N. Pintauro, P. T. Mather, O. Arnoult, J. Choi, R. Wycisk and K. M. Lee, ECS Trans., 2007, 11, 79-87.

184 J. Choi, K. M. Lee, R. Wycisk, P. N. Pintauro and P. T. Mather, Macromolecules, 2008, 41, 4569-4572. 


\section{Cite this: DOI: 10.1039/c0xx00000x}

185 J. Choi, K. M. Lee, R. Wycisk, P. N. Pintauro and P. T. Mather, J. Electrochem. Soc., 2010, 157, B914-B919.

186 J. Choi, K. M. Lee, R. Wycisk, P. N. Pintauro and P. T. Mather, ECS Trans., 2008, 16, 1433-1442.

187 T. Tamura and H. Kawakami, Nano Lett., 2010, 10, 13241328.

${ }^{188}$ C. Subramanian, R. A. Weiss and M. T. Shaw, Polymer, 2009, 51, 1983-1989.

${ }^{189}$ Y. Chen, J. Guo and H. Kim, React. Funct. Polym., 2010, 70, 69-74.

${ }^{190}$ S. Subianto, S. Cavaliere, D. J. Jones and J. Rozière, ECS Trans., 2011, accepted.

${ }^{191}$ Y. Yao, B. Guo, L. Ji, K-H. Jung, Z. Lin, M. Alcoutlabi, H; Hamouda, and X. Zhang, Electrochem. Commun. 2011, 13, 1005-1008

${ }^{192}$ B. O'Regan and M. Grätzel, Nature, 1991, 353, 737-740.

${ }^{193}$ M. Grätzel, J. Photochem. Photobiol. C, 2003, 4, 145-153.

${ }^{194}$ M. Grätzel, J. Photochem. Photobiol. A, 2004, 164, 3-14.

${ }^{195}$ Y. Chiba, A. Islam, Y. Watanabe, R. Komiya, N. Koide and L. Han, Jpn. J. Appl. Phys., 2006, 45, L638-L640.

${ }^{196}$ W. Shockley, H. J. Queisser, J. Appl. Phys., 1961, 32, 510519.

${ }^{197}$ J. Bisquert, D. Cahen, G. Hodes, S. Rühle and A. Zaban, $J$. Phys. Chem.B, 2004, 108, 8106-8118.

${ }^{198} \mathrm{Z}$. Li, C. Rochford, F. Javier Baca, J. Liu, J. Li and J. Wu, Nanoscale Res. Lett., 2010, 5, 1480-1486.

${ }^{199}$ K. Zhu, N.P. Neale, A. Miedaner, A.J. Frank, Nano Lett. 2007, 7, 69-74.

${ }^{200}$ K. Lee, C. Hu, H. Chen, K. Ho, Sol. Energy Mater. Sol. Cells, 2008, 92,1628-1633.

${ }^{201}$ J. Jiu, S. Isoda, F. Wang and M. Adachi, J. Phys. Chem. B, 2006, 110, 2087-2092.

${ }^{202}$ S. H. Kang, S. H. Choi, M. S. Kang, J. Y. Kim, H. S. Kim, T. Hyeon and Y. E. Sung, Adv. Mater., 2008, 20, 54-58.

${ }^{203}$ C. Richter and C. A. Schmuttenmaer, Nature Nanotechnol., $2010,5,769-772$.

204 P. Sudhagar, J. H. Jung, S. Park, Y.-G. Lee, R. Sathyamoorthy, Y. S. Kang and H. Ahn, Electrochem. Comm., 2009, 11, 2220-2224.

${ }^{205}$ M. Y. Song, Y. R. Ahn, S. M. Jo, D. Y. Kim and J.-P. Ahn, Appl. Phys. Lett., 2005, 87, 113113 .

${ }^{206}$ K. Onozuka, B. Ding, Y. Tsuge, T. Naka, M. Yamazaki, S. Sugi, S. Ohno, M. Yoshikawa and S. Shiratori, Nanotechnology, 2006, 17, 1026-1031.

${ }^{207}$ K. Mukherjee, T.-H. Teng, R. Jose and S. Ramakrishna, Appl. Phys. Lett., 2009, 95, 012101.

${ }^{208}$ S. Chuangchote, T. Sagawa and S. Yoshikawa, ECS Trans., 2009, 16, 21-26.

${ }^{209}$ S. Chuangchote, T. Sagawa and S. Yoshikawa, Appl. Phys. Lett., 2008, 93, 033310.

${ }^{210}$ M. Y. Song, D. K. Kim, S. M. Jo and D. Y. Kim, Synth. Met., 2005, 155, 635-638.

${ }^{211}$ L. Francis, A. Sreekumaran Nair, R. Jose, S. Ramakrishna, V. Thavasi, E. Marsano, Energy, 2011, 36, 627-632.

212 T. Krishnamoorthy, V. Thavasi, M. Subodh G and S. Ramakrishna, Energy Environ. Sci. , 2011, 4, 2807-2812.

${ }^{213}$ P. S. Archana, R. Jose, T. M. Jin, C. Vijila, M. M. Yusoff and S. Ramakrishna, J. Am. Ceram. Soc., 2010, 93, 4096-4102.

${ }^{214}$ H.-W. Chen, C.-Y. Lin, Y.-H. Lai, J.-G. Chen, C.-C. Wang, C.-W. Hu, C.-Y. Hsu, R. Vittal and K.-C. Ho, J. Power Sources, 2011, 196, 4859-4864.

${ }^{215}$ M. Law, L. E. Greene, J. C. Johnson, R. Saykally and P. Yang, Nat. Mater., 2005, 4, 455-459.

${ }^{216}$ M. Saito and S. Fujihara, Energy Env. Sci., 2008, 1, 280-283.
${ }^{217}$ I.-D. Kim, J.-M. Hong, B. H. Lee, D. Y. Kim, E.-K. Jeon, D.K. Choi and D.-J. Yang, Appl. Phys. Lett., 2007, 91, 163109.

${ }^{218}$ W. Zhang, R. Zhu, X. Liu, B. Liu and S. Ramakrishna, Appl. Phys. Lett., 2009, 95, 043304.

${ }^{219}$ S. Yun and S. Lim, J. Solid State Chem., 2011, 184, 273-279.

${ }^{220}$ J.-J. Wu, Y.-R. Chen, W.-P. Liao, C.-T. Wu and C.-Y. Chen, ACS Nano, 2010, 4, 5679-5684.

${ }^{221}$ H. E. Unalan, D. Wei, K. Suzuki, S. Dalal, P. Hiralal, H. Matsumoto, S. Imaizumi, M. Minagawa, A. Tanioka, A. J. Flewitt, W. I. Milne and G. A. J. Amaratunga, Appl. Phys. Lett., 2008, 93, 133116.

${ }^{222}$ F. Iskandar, A. B. Suryamas, M. Kawabe, M. M. Munir, K. Okuyama, T. Tarao and T. Nishitani, Jpn. J. Appl. Phys., 2010, 49, 010213.

${ }^{223}$ H. Wu, L. Hu, M. W. Rowell, D. Kong, J. J. Cha, J. R. McDonough, J. Zhu, Y. Yang, M. D. McGehee and Y. Cui, Nano Lett., 2010, 10, 4242-4248.

${ }^{224}$ Q. Tai, X. Zhao and F. Yan, J. Mater. Chem., 2010, 20, 73667371.

${ }^{225}$ S. Wu, Q. Tai and F. Yan, J. Phys. Chem. C, 2010, 114, 61976200.

${ }^{226}$ A. Kay, M. Grätzel, Sol. Energy Mater. Sol. Cells, 1996, 44, 99-117.

${ }^{227}$ P. Hasin, M. A. Alpuche-Aviles, Y. Li, Y. Wu, J. Phys. Chem. C, 2009, 113, 7456-7460.

${ }^{228}$ W. J. Lee, E. Ramasamy, D. Y. Lee, J. S. Song, ACS Appl. Mater. Interfaces, 2009, 1, 1145-1149.

${ }^{229}$ P. Joshi, L. Zhang, Q. Chen, D. Galipeau, H. Fong and Q. Qiao, ACS Appl. Mater. Interfaces, 2010, 2, 3572-3577.

${ }^{230}$ Y. Saito, N. Fukuri, R. Senadeera, T. Kitamura, Y. Wada and S. Yanagida, Electrochem. Comm., 2004, 6, 71-74.

${ }^{231}$ S. A. Haque, E. Palomares, H. M. Upadhyaya, L. Otley, R. J. Potter, A. B. Holmes and J. R. Durrant, Chem. Commun., 2003, 3008-3009.

${ }^{232}$ W. Kubo, T. Kitamura, K. Hanabusa, Y. Wada and S. Yanagida, Chem. Commun., 2002, 374-375.

233 P. Wang, S. M. Zakeeruddin, J. E. Moser, M. K. Nazeeruddin, T. Sekiguchi and M. Grätzel, Nat. Mater., 2003, 2, 402-407.

${ }^{234}$ O. A. Ileperuma, M. A. K. L. Dissanayake, S. Somasunderam and L. R. A. K. Bandara, Sol. Energy Mater. Sol. Cells, $2004,84,117-124$

${ }^{235}$ J. Y. Kim, T. H. Kim, D. Y. Kim, N.-G. Park and K.-D. Ahn, J. Power Sources, 2008, 175, 692-697.

${ }^{236}$ M. Biancardo, K. West and F. C. Krebs, J. Photochem. Photobiol. A, 2007, 187, 395-401.

${ }^{237}$ P. Wang, S. M. Zakeeruddin, I. Exnar and M. Grätzel, Chem. Commun., 2002, 2972-2973.

${ }^{238}$ C. Drew, X. Wang, K. Senecal, H. Schreuder-Gibson, J. He, J. Kumar and L. A. Samuelson, J. Macromol. Sci. A, 2002, 39, 1085 - 1094.

${ }^{239}$ A. R. S. Priya, A. Subramania, Y.-S. Jung and K.-J. Kim, Langmuir, 2008, 24, 9816-9819.

${ }^{240}$ S.-H. Park, J.-U. Kim, S.-Y. Lee, W.-K. Lee, J.-K. Lee and M.-R. Kim, J. Nanosci. Nanotechnol., 2008, 8, 4889-4894.

${ }^{241}$ J.-U. Kim, S.-H. Park, H.-J. Choi, W.-K. Lee, J.-K. Lee and M.-R. Kim, Sol. Energy Mater. Sol. Cells, 2009, 93, 803807.

${ }^{242}$ S.-H. Park, D.-H. Won, H.-J. Choi, W.-P. Hwang, S.-i. Jang, J.-H. Kim, S.-H. Jeong, J.-U. Kim, J.-K. Lee and M.-R. Kim, Sol. Energy Mater. Sol. Cells, 2011, 95, 296-300.

${ }^{243}$ M. Winter and R. J. Brodd, Chem. Rev. 2004, 104, 42454270 


\section{Cite this: DOI: 10.1039/c0xx00000x}

${ }^{244}$ M. M. Thackeray, S.-H. Kang, C. S. Johnson, J. T. Vaughey, R. Benedek and S. A. Hackney, J. Mater. Chem., 2007, 17, 3112-3125.

245 A. S. Aricò, P. Bruce, B. Scrosati, J.-M. Tarascon and W. van Schalkwijk, Nat. Mater., 2005, 4, 366-377.

246 A. Manthiram, A. Vadivel Murugan, A. Sarkar and T. Muraliganth, Energy Environ. Sci., 2008, 1, 621-638.

${ }^{247}$ Y. Wang and G. Cao, Adv. Mater., 2008, 20, 2251-2269.

${ }^{248}$ M. V. Reddy, R. Jose, T. H. Teng, B. V. R. Chowdari and S. Ramakrishna, Electrochim. Acta, 2010, 55, 3109-3117.

${ }^{249}$ E. Hosono, T. Kudo, I. Honma, H. Matsuda and H. Zhou, Nano Lett., 2009, 9, 1045-1051.

${ }^{250}$ L. Mai, L. Xu, C. Han, X. Xu, Y. Luo, S. Zhao and Y. Zhao, Nano Lett., 2010, 10, 4750-4755.

251 C. Ban, N. A. Chernova and M. S. Whittingham, Electrochem. Comm., 2009, 11, 522-525.

${ }^{252}$ A. Le Viet, M. V. Reddy, R. Jose, B. V. R. Chowdari and S. Ramakrishna, Electrochim. Acta, 2011, 56, 1518-1528.

${ }^{253}$ Y. Gu, D. Chen, X. Jiao and F. Liu, J. Mater. Chem., 2007, 17, 1769-1776

${ }^{254}$ E. Hosono, Y. Wang, N. Kida, M. Enomoto, N. Kojima, M. Okubo, H. Matsuda, Y. Saito, T. Kudo, I. Honma and H. Zhou, ACS Appl. Mater. Interfaces, 2009, 2, 212-218.

255 Y. Gu and F. Jian, J. Phys. Chem. C, 2008, 112, 2017620180.

${ }^{256}$ Y. K. Sun, I. H. Oh and S. A. Hong, J. Mater. Sci., 1996, 31, 3617-3621.

${ }^{257}$ L.-J. Chen, J.-D. Liao, Y.-J. Chuang, K.-C. Hsu, Y.-F. Chiang and Y.-S. Fu, J. Appl. Polym. Sci., 2011, 121, 154-160.

${ }^{258}$ Y. Gu, D. Chen and X. Jiao, J. Phys. Chem. B, 2005, 109, 17901-17906.

${ }^{259}$ Z. Yang, C. Cao, F. Liu, D. Chen and X. Jiao, Solid State Ionics, 2010, 181, 678-683.

260 H.-W. Lu, L. Yu, W. Zeng, Y.-S. Li and Z.-W. Fu, Electrochem. Solid-State Lett., 2008, 11, A140-A144.

${ }^{261}$ H. Gabrisch, J. D. Wilcox and M. M. Doeff, Electrochem. Solid-State Lett., 2006, 9, A360-A363.

${ }^{262}$ C. Sisbandini, D. Brandell, T. Gustafsson and L. Nyholm, J. Electrochem. Soc., 2009, 156, A720-A725.

${ }^{263}$ O. Toprakci, L. Ji, Z. Lin, H. A. K. Toprakci and X. Zhang, J. Power Sources, 2011, 196, 7692-7699.

${ }^{264}$ C. Zhu, Y. Yu, L. Gu, K. Weichert and J. Maier, Angew. Chem. Int. Ed., 2011, 50, 6278-6282.

${ }^{265}$ Y. L. Cheah, N. Gupta, S. S. Pramana, V. Aravindan, G. Wee and M. Srinivasan, J. Power Sources, 2011, 196, 6465-6472.

${ }^{266}$ D. Yu, C. Chen, S. Xie, Y. Liu, K. Park, X. Zhou, Q. Zhang, Y. Li and G. Cao, Energy Environ. Sci., 2011, 4, 858-861.

${ }^{267}$ C. Kim, K. S. Yang, M. Kojima, K. Yoshida, Y. J. Kim, Y. A. Kim and M. Endo, Adv. Funct. Mater., 2006, 16, 23932397.

${ }^{268}$ L. Ji, Y. Yao, O. Toprakci, Z. Lin, Y. Liang, Q. Shi, A. J. Medford, C. R. Millns and X. Zhang, J. Power Sources, 2010, 195, 2050-2056.

${ }^{269}$ L. Wang, C. X. Ding, L. C. Zhang, H. W. Xu, D. W. Zhang, T. Cheng and C. H. Chen, J. Power Sources, 2010, 195, 5052-5056.

${ }^{270}$ H. S. Choi, J. G. Lee, H. Y. Lee, S. W. Kim and C. R. Park, Electrochim. Acta, 2010, 56, 790-796.

${ }^{271}$ L. Zou, L. Gan, F. Kang, M. Wang, W. Shen and Z. Huang, $J$. Power Sources, 2010, 195, 1216-1220.

${ }^{272}$ L. Zou, L. Gan, R. Lv, M. Wang, Z.-h. Huang, F. Kang and W. Shen, Carbon, 2011, 49, 89-95.

${ }^{273}$ Y. Yu, L. Gu, C. Wang, A. Dhanabalan, P. A. van Aken and J. Maier, Angew. Chem. Int. Ed., 2009, 48, 6485-6489.
${ }^{274}$ Y. Yu, Q. Yang, D. Teng, X. Yang and S. Ryu, Electrochem. Comm., 2010, 12, 1187-1190.

${ }^{275}$ K. T. Lee, Y. S. Jung and S. M. Oh, J. Am. Chem. Soc., 2003, 125, 5652-5653.

${ }^{276}$ P. Zhang, Z. P. Guo, Y. Huang, D. Jia and H. K. Liu, J. Power Sources, 2011, 196 6987-6991.

${ }^{277}$ L. Wang, Y. Yu, P. C. Chen, D. W. Zhang and C. H. Chen, J. Power Sources, 2008, 183, 717-723.

278 Z. Lin, L. Ji, M. D. Woodroof and X. Zhang, J. Power Sources, 2010, 195, 5025-5031.

${ }^{279}$ F. Badway, I. Plitz, S. Grugeon, S. Laruelle, M. Dolle, A. S. Gozdz and J. M. Tarascon, Electrochem. Solid-State Lett., 2002, 5, A115-A118.

${ }^{280}$ L. Ji, Z. Lin, A. J. Medford and X. Zhang, Chem. Eur. J., 2009, 15, 10718-10722.

${ }^{281}$ Y. Ding, P. Zhang, Z. Long, Y. Jiang, J. Huang, W. Yan and G. Liu, Mater. Lett., 2008, 62, 3410-3412.

${ }^{282}$ N. Zhu, W. Liu, M. Xue, Z. Xie, D. Zhao, M. Zhang, J. Chen and T. Cao, Electrochim. Acta, 2010, 55, 5813-5818.

${ }^{283}$ Z. Yang, G. Du, C. Feng, S. Li, Z. Chen, P. Zhang, Z. Guo, X. Yu, G. Chen, S. Huang and H. Liu, Electrochim. Acta, 2010, 55, 5485-5491.

${ }^{284}$ S. H. Nam, H.-S. Shim, Y.-S. Kim, M. A. Dar, J. G. Kim and W. B. Kim, ACS Appl. Mater. Interfaces, 2010, 2, 20462052.

${ }^{285}$ L. Li, X. Yin, S. Liu, Y. Wang, L. Chen and T. Wang, Electrochem. Comm., 2010, 12, 1383-1386.

${ }^{286}$ S. H. Nam, H.-S. Shim, Y.-S. Kim, M. A. Dar, J. G. Kim and W. B. Kim, ACS Appl. Mater. Interfaces, 2010, 2, 20462052.

287 Q. Fan and M. S. Whittingham, Electrochem. Solid-State Lett., 2007, 10, A48-A51.

${ }^{288}$ D. Deng, M. G. Kim, J. Y. Lee and J. Cho, Energy Environ. Sci., 2009, 2, 818-837.

289 H.-W. Lu, W. Zeng, Y.-S. Li and Z.-W. Fu, J. Power Sources, 2007, 164, 874-879.

${ }^{290}$ S. W. Choi, S. M. Jo, W. S. Lee and Y.-R. Kim, Adv. Mater., 2003, 15, 2027-2032.

${ }^{291}$ J. R. Kim, S. W. Choi, S. M. Jo, W. S. Lee and B. C. Kim, Electrochim. Acta, 2004, 50, 69-75.

${ }^{292}$ J. R. Kim, S. W. Choi, S. M. Jo, W. S. Lee and B. C. Kim, J. Electrochem. Soc., 2005, 152, A295-A300.

${ }^{293}$ S. W. Choi, J. R. Kim, S. M. Jo, W. S. Lee and Y. R. Kim, J. Electrochem. Soc., 2005, 152, A989-A995.

${ }^{294}$ S. W. Lee, S. W. Choi, S. M. Jo, B. D. Chin, D. Y. Kim and K. Y. Lee, J. Power Sources, 2006, 163, 41-46.

${ }^{295}$ X. Li, G. Cheruvally, J.-K. Kim, J.-W. Choi, J.-H. Ahn, K.W. Kim and H.-J. Ahn, J. Power Sources, 2007, 167, 491498.

${ }^{296}$ G. Cheruvally, J.-K. Kim, J.-W. Choi, J.-H. Ahn, Y.-J. Shin, J. Manuel, P. Raghavan, K.-W. Kim, H.-J. Ahn, D. S. Choi and C. E. Song, J. Power Sources, 2007, 172, 863-869.

${ }^{297}$ P. Raghavan, J.-W. Choi, J.-H. Ahn, G. Cheruvally, G. S. Chauhan, H.-J. Ahn and C. Nah, J. Power Sources, 2008, 184, 437-443.

${ }^{298}$ P. Raghavan, X. Zhao, J.-K. Kim, J. Manuel, G. S. Chauhan, J.-H. Ahn and C. Nah, Electrochim. Acta, 2008, 54, 228234.

299 D. Bansal, B. Meyer and M. Salomon, J. Power Sources, 2008, 178, 848-851.

${ }^{300}$ T.-H. Cho, M. Tanaka, H. Onishi, Y. Kondo, T. Nakamura, H. Yamazaki, S. Tanase and T. Sakai, J. Power Sources, $2008, \mathbf{1 8 1}, 155-160$ 


\section{Cite this: DOI: 10.1039/c0xx00000x}

${ }^{301}$ J.-K. Kim, G. Cheruvally, X. Li, J.-H. Ahn, K.-W. Kim and H.-J. Ahn, J. Power Sources, 2008, 178, 815-820.

${ }^{302}$ H.-R. Jung, D.-H. Ju, W.-J. Lee, X. Zhang and R. Kotek, Electrochim. Acta, 2009, 54, 3630-3637.

${ }^{303}$ C. Yang, Z. Jia, Z. Guan and L. Wang, J. Power Sources, 2009, 189, 716-720.

${ }^{304}$ P. Raghavan, X. Zhao, C. Shin, D.-H. Baek, J.-W. Choi, J. Manuel, M.-Y. Heo, J.-H. Ahn and C. Nah, J. Power Sources, 2010, 195, 6088-6094.

${ }^{305}$ P. Raghavan, X. Zhao, J. Manuel, C. Shin, M.-Y. Heo, J.-H. Ahn, H.-S. Ryu, H.-J. Ahn, J.-P. Noh and G.-B. Cho, Mat. Res. Bull., 2010, 45, 362-366.

306 Y.-S. Lee, Y. B. Jeong and D.-W. Kim, J. Power Sources, 2010, 195, 6197-6201.

307 Y.-J. Kim, C. H. Ahn, M. B. Lee and M.-S. Choi, Mater. Chem. Phys., 2011, 127, 137-142.

${ }^{308}$ F. Croce, M. L. Focarete, J. Hassoun, I. Meschini and B. Scrosati, Energy Environ. Sci., 2011, 4, 921-927.

${ }^{309}$ Y. Liang, L. Ji, B. Guo, Z. Lin, Y. Yao, Y. Li, M. Alcoutlabi, Y. Qiu and X. Zhang, J. Power Sources, 2011, 196, 436441.

${ }^{310}$ Y. M. Vol'fkovich and T. M. Serdyuk, Russ. J. Electrochem., 2002, 38, 935-959.

311 J. Gamby, P. L. Taberna, P. Simon, J. F. Fauvarque and M. Chesneau, J. Power Sources, 2001, 101, 109-116.

312 V. Khomenko, E. Raymundo-Piñero, F. Béguin. J. Power Sources., 2010, 195, 4234-4241

313 A. Janes, K. Tonurist, T. Thomberg and E. Lust, ECS Trans., 2009, 19, 23-32.

314 C. Kim and K. S. Yang, Appl. Phys. Lett., 2003, 83, 12161218.

315 C. Kim, K.-S. Yang and W.-J. Lee, Electrochem. Solid-State Lett., 2004, 7, A397-A399.

${ }^{316}$ C. Kim, S.-H. Park, W.-J. Lee and K.-S. Yang, Electrochim. Acta, 2004, 50, 877-881.

${ }^{317}$ C. Kim, Y.-O. Choi, W.-J. Lee and K.-S. Yang, Electrochim. Acta, 2004, 50, 883-887.

${ }^{318}$ K. S. Yang, C. Kim, S. H. Park, J. H. Kim and W. J. Lee, J. Biomed. Nanotechnol., 2006, 2, 103-105.

${ }^{319}$ C. Kim, B. T. N. Ngoc, K. S. Yang, M. Kojima, Y. A. Kim, Y. J. Kim, M. Endo and S. C. Yang, Adv. Mater., 2007, 19, 2341-2346.

${ }^{320}$ S.-J. Park and S.-H. Im, Bull. Korean Chem. Soc., 2008, 29, 777-781.

${ }^{321}$ Q. Guo, X. Zhou, X. Li, S. Chen, A. Seema, A. Greiner and H. Hou, J. Mater. Chem., 2009, 19, 2810-2816.

${ }^{322}$ M.-K. Seo and S.-J. Park, Mater. Sci. Eng., B, 2009, 164, 106-111.

${ }^{323}$ B.-H. Kim, N.-N. Bui, K.-S. Yang, C. M. E. dela and J. P. Ferraris, Bull. Korean Chem. Soc., 2009, 30, 1967-1972.

${ }^{324}$ J. Li, E.-h. Liu, W. Li, X.-y. Meng and S.-T. Tan, J. Alloys Compd., 2009, 478, 371-374.

${ }^{325}$ H. Niu, J. Zhang, Z. Xie, X. Wang and T. Lin, Carbon, 2011, 49, 2380-2388.

${ }^{326}$ M. Rose, E. Kockrick, I. Senkovska and S. Kaskel, Carbon, 2009, 48, 403-407.

${ }^{327}$ A. Laforgue, J. Power Sources, 2011, 196, 559-564.

${ }^{328}$ G. Wee, H. Z. Soh, Y. L. Cheah, S. G. Mhaisalkar and M. Srinivasan, J. Mater. Chem., 2010, 20, 6720-6725.

${ }^{329}$ D.-Y. Youn, H. L. Tuller, T.-S. Hyun, D.-K. Choi and I.-D. Kim, J. Electrochem. Soc., 2011, 158, A970-A975.

${ }^{330}$ F. Moser, L. Athouel, O. Crosnier, F. Favier, D. Belanger, and T. Brousse, Electrochem. Comm. 2009, 11, 1259-1261.
${ }^{331}$ Y. R. Ahn, C. R. Park, S. M. Jo and D. Y. Kim, Appl. Phys. Lett. , 2007, 90, 122106.

332 J.-B. Lee, S.-Y. Jeong, W.-J. Moon, T.-Y. Seong and H.-J. Ahn, J. Alloys Compd., 2011, 509, 4336-4340.

333 T.-S. Hyun, H. L. Tuller, D.-Y. Youn, H.-G. Kim and I.-D. Kim, J. Mater. Chem., 2010, 20, 9172-9179.

${ }^{334}$ S.-H. Choi, T.-S. Hyun, H. Lee, S.-Y. Jang, S.-G. Oh and I.D. Kim, Electrochem. Solid-State Lett., 2010, 13, A65-A68.

${ }^{335}$ J. Mu, B. Chen, Z. Guo, M. Zhang, Z. Zhang, C. Shao and Y. Liu, J. Colloid Interface Sci., 2011, 356, 706-712.

${ }^{336}$ D. K. Hwang, S. Kim, J.-H. Lee, I.-S. Hwang and I.-D. Kim, J. Mater. Chem., 2011, 21, 1959-1965.

337 T.-S. Hyun, J.-E. Kang, H.-G. Kim, J.-M. Hong and I.-D. Kim, Electrochem. Solid-State Lett., 2009, 12, A225-A228.

${ }^{338}$ X. Zhou, C. Shang, L. Gu, S. Dong, X. Chen, P. Han, L. Li, J. Yao, Z. Liu, H. Xu, Y. Zhu and G. Cui, ACS Appl. Mater. Interfaces, 2011, 3, 3058-3063.

${ }^{339}$ A. Varesano, R. A. Carletto, G. Mazzuchetti, J. Mater. Proc. Technol. 2009, 209, 5178-5185

${ }^{340}$ G. H. Kim, Y.-S. Cho, W. D. Kim, Eur. Polym. J., 2006, 42, 2031-2038. 